Prepared for the U.S. Department of Energy

under Contract DE-AC05-76RL01830

\title{
FY14 Q1 Progress Report for SECA Core Technology Program
}

\begin{abstract}
JW Stevenson
BJ Koeppel
\end{abstract}

January 2014

\section{Pacific Northwest}

NATIONAL LABORATORY

Proudly Operated by Battelle Since 1965 


\title{
DISCLAIMER
}

This report was prepared as an account of work sponsored by an agency of the United States Government. Neither the United States Government nor any agency thereof, nor Battelle Memorial Institute, nor any of their employees, makes any warranty, express or implied, or assumes any legal liability or responsibility for the accuracy, completeness, or usefulness of any information, apparatus, product, or process disclosed, or represents that its use would not infringe privately owned rights. Reference herein to any specific commercial product, process, or service by trade name, trademark, manufacturer, or otherwise does not necessarily constitute or imply its endorsement, recommendation, or favoring by the United States Government or any agency thereof, or Battelle Memorial Institute. The views and opinions of authors expressed herein do not necessarily state or reflect those of the United States Government or any agency thereof.

\author{
PACIFIC NORTHWEST NATIONAL LABORATORY \\ operated by \\ BATTELLE \\ for the \\ UNITED STATES DEPARTMENT OF ENERGY \\ under Contract DE-AC05-76RL01830
}

Printed in the United States of America
Available to DOE and DOE contractors from the Office of Scientific and Technical Information,
P.O. Box 62, Oak Ridge, TN 37831-0062;
ph: (865) 576-8401
fax: $(865)$ 576-5728
email: reports@adonis.osti.gov

\begin{abstract}
Available to the public from the National Technical Information Service, U.S. Department of Commerce, 5285 Port Royal Rd., Springfield, VA 22161 ph: (800) 553-6847 fax: $(703) 605-6900$ email: orders@ntis.fedworld.gov online ordering: http://www.ntis.gov/ordering.htm
\end{abstract}

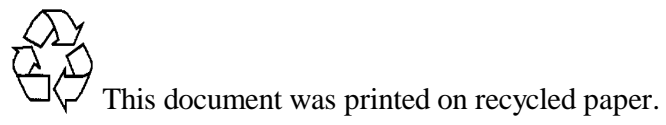


PNNL-23152

\section{FY14 Q1 Progress Report for SECA Core Technology Program}

JW Stevenson

BJ Koeppel

January 2014

Prepared for the U.S. Department of Energy under Contract DE-AC05-76RL01830

Pacific Northwest National Laboratory

Richland, Washington 99352 


\section{Table of Contents}

$\begin{array}{lr}\text { Executive Summary } & 2\end{array}$

Task 1: Materials Development

Metallic Interconnects and Coatings $\quad 4$

$\begin{array}{ll}\text { Stack Test Fixture } & 18\end{array}$

Glass Seal Development $\quad 33$

$\begin{array}{ll}\text { Anode Development } & 37\end{array}$

Task 2: SOFC Modeling

Coarse methodology $\quad 45$

Glass Seals $\quad 52$

$\begin{array}{ll}\text { Metallic Interconnects } & 56\end{array}$

Electrochemistry, Coal Gas, and Secondary Reactions 61

Task 3: Experimental Support of Modeling

$\begin{array}{ll}\text { Interfacial stress and degradation } & 62\end{array}$

Quantification of glass seal behavior $\quad 62$ 


\section{Executive Summary}

This quarterly progress report was prepared under field work proposal (FWP) 40552 and covers technical work performed during the period October 1 through December 31, 2013 (FY14 1st quarter). The report highlights and documents technical progress and milestone status in tasks related to advanced cell and stack component materials development and computational design and simulation.

Technical highlights related to cell and stack materials development and characterization include:

- Surface modified, Ce-modified MC spinel-coated AISI 441 exhibited improved spallation resistance (compared to coated mill reference 441) after 30,000 hours of oxidation at $800^{\circ} \mathrm{C}$ in air. Similar beneficial results from surface modification were observed after 26,000 hours of oxidation at $850^{\circ} \mathrm{C}$.

- MnCo spinel coatings prepared from metallic powder precursors exhibited low area-specific resistance after 12,000 hours of testing at $800^{\circ} \mathrm{C}$.

- Long-term validation tests (6,000 hours of operation followed by 10 deep thermal cycles) of surface-blasted, spinel-coated AISI 441 interconnects were completed using PNNL's SECA CTP stack test fixture. Results of post-test results will be reported in the next quarterly progress report.

- Long-term evaluation of compliant glass seals (SCN-1 glass with YSZ fibers) was in progress using PNNL's SECA CTP stack test fixture.

- Baseline testing of LSCF-based cells from Fuel Cell Materials was performed in PNNL's SECA CTP stack test fixture. Overall performance was similar to that previously obtained with similar cells from H.C. Starck.

- A study on pore coarsening of compliant glass seals with and without inert fillers $\left(\mathrm{ZrO}_{2}\right.$ short fibers or $\mathrm{ZrO}_{2}$ crushed hollow balls) has reached 2,000 hours of testing; results to date indicate that the addition of the fillers was partially effective in hindering the pore coalescence process.

- Cell tests attempting to correlate effects of fuel water content on anode performance with previously observed changes in Ni/YSZ anode microstructure were initiated.

Technical highlights in the computational modeling area include:

- A method to interface the 3D SOFC-MP modeling tool with commercial FEA codes ABAQUS and ANSYS was developed to facilitate model construction and output of the predicted temperature field for structural stress analyses of stacks.

- The error estimation and verification tools of the reduced order modeling (ROM) framework was improved to facilitate error handling for a large number of cases and perform userspecified test cases for error analysis of the generated ROM.

- Mechanical behavior and damage characteristics of the compliant glass seal was investigated for a large planar cell design under different realistic electrochemical operating conditions (as predicted using SOFC-MP 3D) and thermal cycling events.

- The methodology for lifetime prediction of the interconnect was improved to include the mechanical influence of the spinel protection coating on the prediction of critical scale thickness. 
- Experimental characterization of the crack healing rate was performed for compliant glass SCN-1 with various amounts of fiber reinforcement. This information is needed for modeling evaluations of compliant seal healing during stack operations. 


\section{PNNL SECA Core Technology Program FY14 First Quarter Progress Report}

\section{Task 1: Materials Development (Task Leader: Jeff Stevenson)}

The following report summarizes progress achieved by PNNL's SECA Core Technology Program Materials Development team during the first quarter of FY14. There are currently five primary areas of investigation in the Materials Development task: Interconnects (including Coatings), Stack Fixture Testing, Cathode Materials, Anode Materials, and Seals. Selected recent highlights from these activities are reported below.

Metallic Interconnects and Coatings (Jeff Stevenson, Jung Pyung Choi, Eric Riel)

Milestone: Complete 30,000 hour, $800^{\circ} \mathrm{C}$ oxidation/spallation resistance study on surface-treated, spinel-coated AISI 441.

Status: Completed.

Summary:

In previous work at PNNL, oxidation studies were performed at 800 and $850^{\circ} \mathrm{C}$ on AISI 441 coupons coated with Ce-modified MnCo spinel (Ce-MC). As expected, the oxidation kinetics were faster at the higher temperature, and coated AISI 441 coupons oxidized in air at $850^{\circ} \mathrm{C}$ exhibited spallation at the scale / alloy interface after $\sim 1500$ hours. No obvious differences in coating / scale / alloy chemistry were observed during post-test SEM/EDS analysis, suggesting that the spallation may have been primarily related to increased thermal stresses (due to CTE mismatch) resulting from increased oxide scale thickness at the higher temperature.

To mitigate possible spallation issues, a variety of physical surface modifications to the AISI 441 were investigated. Allegheny Ludlum provided sheet stock (0.02" thick) of AISI 441 with five surface conditions:

1. Mill reference (as would be provided to a customer without any additional modifications)

2. De-siliconized (treatment to sequester silicon from the near surface of the sheet; an alternative to decreasing Si content of alloy)

3. Surface blasted (a grit/shot blast process resulting in surface deformation)

4. Surface ground (rough surface abrasion resulting in surface deformation)

5. Temper rolled (cold rolling process)

\section{Oxidation at $800^{\circ} \mathrm{C}$}

Coupons of the surface-treated steel were coated with Ce-MC spinel and subjected to oxidation testing in air at $800^{\circ} \mathrm{C}$. At 2,000 hour intervals, the coupons were cooled down to room temperature and examined. One coupon from each surface treatment was removed from the study for SEM evaluation, while the rest of the coupons were reheated to $800^{\circ} \mathrm{C}$ for continued testing. 
After 2,000 hours, no spallation was observed on any of the specimens. After another 2,000 hours (total oxidation time of 4,000 hours), the coupons were again cooled to room temperature and examined. Spallation was observed on a few coupons (i.e., 1 of 14 mill reference coupons, and 2 of 14 coupons of NETL-Albany samples). After another 2,000 hours (total oxidation time of 6,000 hours), the coupons were again cooled and examined. Extensive spallation was observed on the mill reference coupons, while only one of the surface-treated coupons (a de-siliconized 441 coupon) exhibited spallation. SEM montages of the 6,000 hour coupons were included in a previous quarterly report. While no spallation was observed during visual examination of the cold rolled coupon, SEM analysis revealed complete de-bonding of the oxide scale, possibly due to stresses occurring during the metallographic preparation of the sample. After another 2,000 hours (total oxidation time of 8,000 hours), the last of the mill reference coupons exhibited spallation, but no spallation was observed on the surface-modified coupons. Similar to the 6,000 hour results, no spallation was observed during visual examination of the cold rolled coupon, but SEM analysis revealed complete de-bonding of the oxide scale from the alloy substrate. SEM/EDS analysis on the $800^{\circ} \mathrm{C}, 8,000$ hour surface-blasted sample indicated negligible diffusion of $\mathrm{Cr}$ from the alloy and scale into the protective coating. After another 2,000 hours (total oxidation time of 10,000 hours), no spallation was observed on the samples, although again cross-section SEM analysis indicated de-bonding at the alloy/scale interface for the cold-rolled coupon. After another 2,000 hours (total oxidation time of 12,000 hours at $800^{\circ} \mathrm{C}$ ), no spallation was observed, except for localized spallation on one of the remaining surface ground coupons. SEM analysis revealed localized scale de-bonding was on the surface ground coupon. SEM/EDS analysis on the 12,000 hour surface-blasted sample indicated minimal diffusion of $\mathrm{Cr}$ from the alloy and scale into the protective coating. After another 2,000 hours (total oxidation time of 14,000 hours at $800^{\circ} \mathrm{C}$ ), no spallation was observed. Cross-section SEM analysis revealed localized scale de-bonding for the de-siliconized coupon. SEM/EDS analysis on the 14,000 hour surface-blasted sample indicated minimal diffusion of $\mathrm{Cr}$ from the alloy and scale into the protective coating. After another 2,000 hours (total oxidation time of 16,000 hours), spallation was observed on two of the remaining surface ground coupons. After another 2,000 hours (total oxidation time of 18,000 hours), none of the remaining coupons exhibited visible spallation. Cross-section SEM montages indicated no localized scale debonding, and SEM/EDS analysis on the 18,000 hour surface-blasted sample indicated minimal diffusion of $\mathrm{Cr}$ from the alloy and scale into the protective coating. After another 2,000 hours (total oxidation time of 20,000 hours), none of the remaining coupons exhibited visible spallation, except for one of the surface-ground coupons. Localized de-bonding at the scale/alloy interface was evident for the surface ground and de-siliconized coupons. Crosssection SEM/EDS analysis on the 20,000 hour surface-blasted sample indicated minimal diffusion of $\mathrm{Cr}$ from the alloy and scale into the protective coating. After another 2,000 hours (total oxidation time of 22,000 hours), none of the remaining coupons exhibited visible spallation, except for another one of the surface-ground coupons. After three more 2,000 hour time segments (with a deep thermal cycle after total oxidation times of 24,000, 26,000 hours, and 28,000 hours), none of the remaining coupons exhibited visible spallation.

After another 2,000 hours (total oxidation time of 30,000 hours), none of the remaining coupons exhibited visible spallation. Cross-section SEM analysis revealed some localized debonding at the scale/alloy interface of the surface ground coupon; representative SEM images are shown in Figures 1-4 for the surface blast, surface grind, de-siliconized, and cold-rolled coupons, respectively. As expected, the thickness of the chromia-based scale continued to increase slowly 
with increasing oxidation time (see Figure 5). Cross-section EDS analysis on the surface-blasted sample also revealed increased diffusion of $\mathrm{Cr}$ from the alloy and scale into the protective coating compared to the 20,000 hour sample (see Figure 6 and Table I). Table II summarizes the $800^{\circ} \mathrm{C}$ oxidation results for the various surface treatments out to 30,000 hours.

\section{Oxidation at $850^{\circ} \mathrm{C}$}

A similar set of coupons of the Allegheny Ludlum surface treated steel was subjected to oxidation testing in air at $850^{\circ} \mathrm{C}$. After 4,000 hours of oxidation (performed in two 2,000 hour intervals), no spallation was observed, although SEM analysis of the mill reference 4,000 hour coupon revealed signs of incipient de-bonding at the scale/alloy interface. After another 2,000 hours (total oxidation time of 6,000 hours), no spallation was observed, although cross-section SEM analysis of the mill reference coupon revealed extensive de-bonding at the scale/alloy interface. After another 2,000 hours (total oxidation time of 8,000 hours), no spallation was observed, although cross-section SEM analysis of two coupons (mill reference and desiliconized) revealed de-bonding at the scale/alloy interface. After another 2,000 hours (total oxidation time of 10,000 hours at $850^{\circ} \mathrm{C}$ ), spallation was observed on mill reference and temper rolled coupons. Cross-section SEM analysis of the 10,000 hour coupons revealed extensive scale de-bonding for the de-siliconized coupon. SEM/EDS analysis on the 10,000 hour surface-blasted sample indicated minimal diffusion of $\mathrm{Cr}$ from the alloy and scale into the protective coating. After another 2,000 hours (total oxidation time of 12,000 hours at $850^{\circ} \mathrm{C}$ ), more spallation was observed on mill reference and temper rolled coupons, as well as preliminary spallation on two of the temper rolled coupons. Cross-section SEM montages of the coupons removed after 12,000 hours indicated extensive de-bonding at the scale/alloy interface of the de-siliconized sample. Cross-section SEM/EDS analysis on the 12,000 hour surface-blasted sample indicated minimal diffusion of $\mathrm{Cr}$ from the alloy and scale into the protective coating. After another 2,000 hours (total oxidation time of 14,000 hours at $850^{\circ} \mathrm{C}$ ), spallation was observed on mill reference, desiliconized, and temper rolled coupons, and SEM analysis revealed localized de-bonding at the scale/alloy interface of the de-siliconized sample. Cross-section SEM/EDS analysis on the 14,000 hour surface-ground sample indicated minimal diffusion of $\mathrm{Cr}$ from the alloy and scale into the protective coating. After another 2,000 hours (total oxidation time of 16,000 hours at $850^{\circ} \mathrm{C}$ ), spallation was observed on the last remaining mill reference coupons. After another 2,000 hours (total oxidation time of 18,000 hours at $850^{\circ} \mathrm{C}$ ), no spallation was observed on the remaining coupons. After another 2,000 hours (total oxidation time of 20,000 hours at $850^{\circ} \mathrm{C}$ ), no spallation was observed on the remaining coupons, except for the de-siliconized coupons, all of which spalled. After two more 2,000 hour time segments (with a deep thermal cycle after total oxidation times of 22,000 and 24,000 hours), none of the remaining coupons exhibited visible spallation.

After another 2,000 hours (total oxidation time of 26,000 hours), none of the remaining coupons exhibited visible spallation. Representative cross-section SEM images are shown in Figures 7-9 for the surface blast, surface grind, and cold-rolled coupons, respectively. As expected, the thickness of the chromia-based scale continued to increase slowly with increasing oxidation time (see Figure 10). Cross-section EDS analysis on the surface-blasted sample revealed increased diffusion of $\mathrm{Cr}$ from the alloy and scale into the protective coating compared to the 20,000 hour sample (see Figure 11 and Table III). Table IV summarizes the $850^{\circ} \mathrm{C}$ oxidation results for the various surface treatments out to 26,000 hours. 
Table I. EDS results for the regions shown in Figure 6 (atomic \%).

\begin{tabular}{|c|c|c|c|c|c|c|c|c|c|c|}
\hline Spectrum & 0 & Al & $\mathrm{Si}$ & $\mathrm{Ti}$ & V & $\mathrm{Cr}$ & $\mathrm{Mn}$ & $\mathrm{Fe}$ & Co & $\mathrm{Ce}$ \\
\hline Spectrum 1 & 58.74 & & & 0.69 & & 6.63 & 16.81 & 3.90 & 13.06 & 0.18 \\
\hline Spectrum 2 & 58.09 & & & 0.67 & & 7.50 & 16.58 & 3.89 & 13.13 & 0.14 \\
\hline Spectrum 3 & 59.02 & & & 0.61 & & 8.15 & 15.60 & 3.70 & 12.83 & 0.09 \\
\hline Spectrum 4 & 57.98 & & 0.42 & 0.56 & & 9.57 & 15.12 & 3.52 & 12.66 & 0.17 \\
\hline Spectrum 5 & 58.03 & & 0.26 & 0.54 & & 11.55 & 13.91 & 3.23 & 12.34 & 0.13 \\
\hline Spectrum 6 & 58.43 & & & 0.68 & & 9.09 & 15.29 & 3.65 & 12.66 & 0.21 \\
\hline Spectrum 7 & 57.01 & & 0.31 & 0.76 & & 8.37 & 16.28 & 3.83 & 12.99 & 0.45 \\
\hline Spectrum 8 & 62.54 & & & 0.18 & & 35.98 & 0.76 & 0.22 & 0.32 & \\
\hline Spectrum 9 & 62.05 & & 0.26 & 0.23 & & 36.45 & 0.60 & 0.24 & 0.17 & \\
\hline Spectrum 10 & 61.80 & & & 0.33 & & 37.00 & 0.58 & 0.28 & & \\
\hline Spectrum 11 & 59.46 & & 0.68 & 0.66 & 0.14 & 37.47 & 0.53 & 1.05 & & \\
\hline Spectrum 12 & 5.44 & 0.45 & 1.00 & 0.77 & & 18.07 & & 74.27 & & \\
\hline Spectrum 13 & & 0.51 & 1.09 & 0.65 & & 17.69 & & 80.05 & & \\
\hline
\end{tabular}

Table II. Summary of results of $800^{\circ} \mathrm{C}$ oxidation study.

\begin{tabular}{|c|c|c|c|c|c|c|c|c|c|c|}
\hline \multirow[t]{2}{*}{\begin{tabular}{|l|} 
Time \\
(h)
\end{tabular}} & \begin{tabular}{|l} 
Mill \\
Reference \\
(1200 grit)
\end{tabular} & & \begin{tabular}{|l|} 
Temper \\
Rolled
\end{tabular} & & $\begin{array}{l}\text { De- } \\
\text { siliconized }\end{array}$ & & $\begin{array}{l}\text { Surface } \\
\text { Grind }\end{array}$ & & $\begin{array}{l}\text { Surface } \\
\text { Blast }\end{array}$ & \\
\hline & $\begin{array}{l}\text { Macroscopic } \\
\text { Spallation }\end{array}$ & $\begin{array}{l}\text { Microscopic } \\
\text { De-bonding }\end{array}$ & $\begin{array}{l}\text { Macroscopic } \\
\text { Spallation }\end{array}$ & \begin{tabular}{|l|} 
Microscopic \\
De-bonding
\end{tabular} & $\begin{array}{l}\text { Macroscopic } \\
\text { Spallation }\end{array}$ & $\begin{array}{l}\text { Microscopic } \\
\text { De-bonding }\end{array}$ & $\begin{array}{l}\text { Macroscopic } \\
\text { Spallation }\end{array}$ & $\begin{array}{l}\text { Microscopic } \\
\text { De-bonding }\end{array}$ & $\begin{array}{l}\text { Macroscopic } \\
\text { Spallation }\end{array}$ & $\begin{array}{l}\text { Microscopic } \\
\text { De-bonding }\end{array}$ \\
\hline \multicolumn{11}{|l|}{2000} \\
\hline 4000 & $x$ & & & & & & & & & \\
\hline 6000 & $x$ & & & C & $x$ & & & & & \\
\hline 8000 & $x$ & & & c & & & & & & \\
\hline 10000 & $x x$ & $x x$ & & C & & & & L & & \\
\hline 12000 & $x x$ & $x x$ & & & & & $x$ & L & & \\
\hline 14000 & $x x$ & $x x$ & & & & L & & & & \\
\hline 16000 & $x x$ & $\mathrm{xx}$ & & & & & & & & \\
\hline 18000 & $x x$ & $x x$ & & & & & & & & \\
\hline 20000 & $x x$ & $x x$ & & & & L & $x$ & L & & \\
\hline 22000 & $x x$ & $x x$ & & \# & & \# & $x$ & \# & & $\#$ \\
\hline 24000 & $x x$ & $x x$ & & $\#$ & & $\#$ & & \# & & $\#$ \\
\hline 26000 & $x x$ & $x$ & & \# & & $\#$ & & \# & & $\#$ \\
\hline 28000 & $\mathrm{xx}$ & 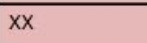 & & \# & & \# & & $\#$ & & \# \\
\hline 30000 & $x x$ & $x x$ & & & & & & L & & \\
\hline
\end{tabular}

$\mathrm{X}$ - spallation on at least one coupon

$\mathrm{XX}$ - no unspalled coupons left in study

$\mathrm{C}$ - complete de-bonding of scale of SEM/EDS sample

L - localized de-bonding of scale of SEM/EDS sample

\# - coupon not removed for analysis due to limited \# of coupons remaining in study 
Table III. EDS results for the regions shown in Figure 11 (atomic \%).

\begin{tabular}{|c|c|c|c|c|c|c|c|c|c|c|c|}
\hline Spectrum & Si & $\mathrm{Ti}$ & V & $\mathrm{Cr}$ & $\mathrm{Mn}$ & $\mathrm{Fe}$ & Co & $\mathrm{Ni}$ & $\mathrm{Zn}$ & $\mathrm{Nb}$ & $\mathrm{Ce}$ \\
\hline Spectrum 1 & & 0.32 & & 5.84 & 19.77 & 2.24 & 13.98 & & & & 0.32 \\
\hline Spectrum 2 & & 0.36 & & 7.26 & 19.98 & 2.19 & 14.16 & & & & 0.88 \\
\hline Spectrum 3 & 0.34 & 0.33 & & 6.60 & 18.27 & 2.05 & 13.23 & & & & 0.38 \\
\hline Spectrum 4 & 0.39 & 0.33 & & 8.01 & 16.96 & 1.98 & 12.82 & & & & \\
\hline Spectrum 5 & 0.59 & 0.23 & & 12.01 & 13.68 & 1.62 & 11.99 & & 0.03 & & \\
\hline Spectrum 6 & 0.59 & 0.13 & & 17.61 & 9.61 & 1.13 & 11.12 & & & & \\
\hline Spectrum 7 & 0.23 & 0.12 & & 34.78 & 0.74 & 0.18 & 0.18 & & 0.03 & & \\
\hline Spectrum 8 & 0.74 & 0.27 & & 34.78 & 0.67 & 0.21 & & & & & \\
\hline Spectrum 9 & 1.10 & 0.35 & & 34.16 & 0.65 & 1.19 & & & & & \\
\hline Spectrum 10 & 4.82 & 0.89 & 0.47 & 21.68 & & 31.42 & & & & 1.33 & \\
\hline Spectrum 11 & 1.52 & 0.31 & & 15.58 & & 82.08 & & 0.51 & & & \\
\hline Spectrum 12 & 0.85 & & & 14.38 & & 84.31 & & 0.47 & & & \\
\hline
\end{tabular}

Table IV. Summary of results of $850^{\circ} \mathrm{C}$ oxidation study.

\begin{tabular}{|c|c|c|c|c|c|c|c|c|c|c|}
\hline $\begin{array}{l}\text { Time } \\
\text { (h) }\end{array}$ & $\begin{array}{l}\text { Mill } \\
\text { Reference } \\
\text { (1200 grit) }\end{array}$ & & $\begin{array}{l}\text { Temper } \\
\text { Rolled }\end{array}$ & & $\begin{array}{l}\text { De- } \\
\text { siliconized }\end{array}$ & & $\begin{array}{l}\text { Surface } \\
\text { Grind }\end{array}$ & & $\begin{array}{l}\text { Surface } \\
\text { Blast }\end{array}$ & \\
\hline & $\begin{array}{l}\text { Macroscopic } \\
\text { Spallation }\end{array}$ & $\begin{array}{l}\text { Microscopic } \\
\text { De-bonding }\end{array}$ & $\begin{array}{l}\text { Macroscopic } \\
\text { Spallation }\end{array}$ & $\begin{array}{l}\text { Microscopic } \\
\text { De-bonding }\end{array}$ & $\begin{array}{l}\text { Macroscopic } \\
\text { Spallation }\end{array}$ & $\begin{array}{l}\text { Microscopic } \\
\text { De-bonding }\end{array}$ & $\begin{array}{l}\text { Macroscopic } \\
\text { Spallation }\end{array}$ & $\begin{array}{l}\text { Microscopic } \\
\text { De-bonding }\end{array}$ & $\begin{array}{l}\text { Macroscopic } \\
\text { Spallation }\end{array}$ & $\begin{array}{l}\text { Microscopic } \\
\text { De-bonding }\end{array}$ \\
\hline \multicolumn{11}{|l|}{2000} \\
\hline 4000 & & L & & & & & & & & \\
\hline 6000 & & C & & & & & & & & \\
\hline 8000 & & C & & & & C & & & & \\
\hline 10000 & $x$ & & $x$ & & & C & & & & \\
\hline 12000 & $x$ & & $x$ & & $x$ & C & & & & \# \\
\hline 14000 & $x$ & & $x$ & & $x$ & L & & & & \# \\
\hline 16000 & $x x$ & $x x$ & & $\#$ & & $\#$ & & $\#$ & & $\#$ \\
\hline 18000 & $x x$ & $x x$ & & $\#$ & & $\#$ & & $\#$ & & \# \\
\hline 20000 & $x x$ & $x x$ & & & $x x$ & $x x$ & & & & \\
\hline 22000 & $x x$ & $x x$ & & $\#$ & $x x$ & $x x$ & & $\#$ & & $\#$ \\
\hline 24000 & $x x$ & $x x$ & & $\#$ & $x x$ & $x x$ & & $\#$ & & \# \\
\hline 26000 & $x x$ & $x x$ & & & $x x$ & $x x$ & & & & \\
\hline
\end{tabular}

$\mathrm{X}$ - spallation on at least one coupon

$\mathrm{XX}$ - no unspalled coupons left in study

$\mathrm{C}$ - complete de-bonding of scale of SEM/EDS sample

$\mathrm{L}$ - localized de-bonding of scale of SEM/EDS sample

\# - coupon not removed for analysis due to limited number of coupons remaining in study 


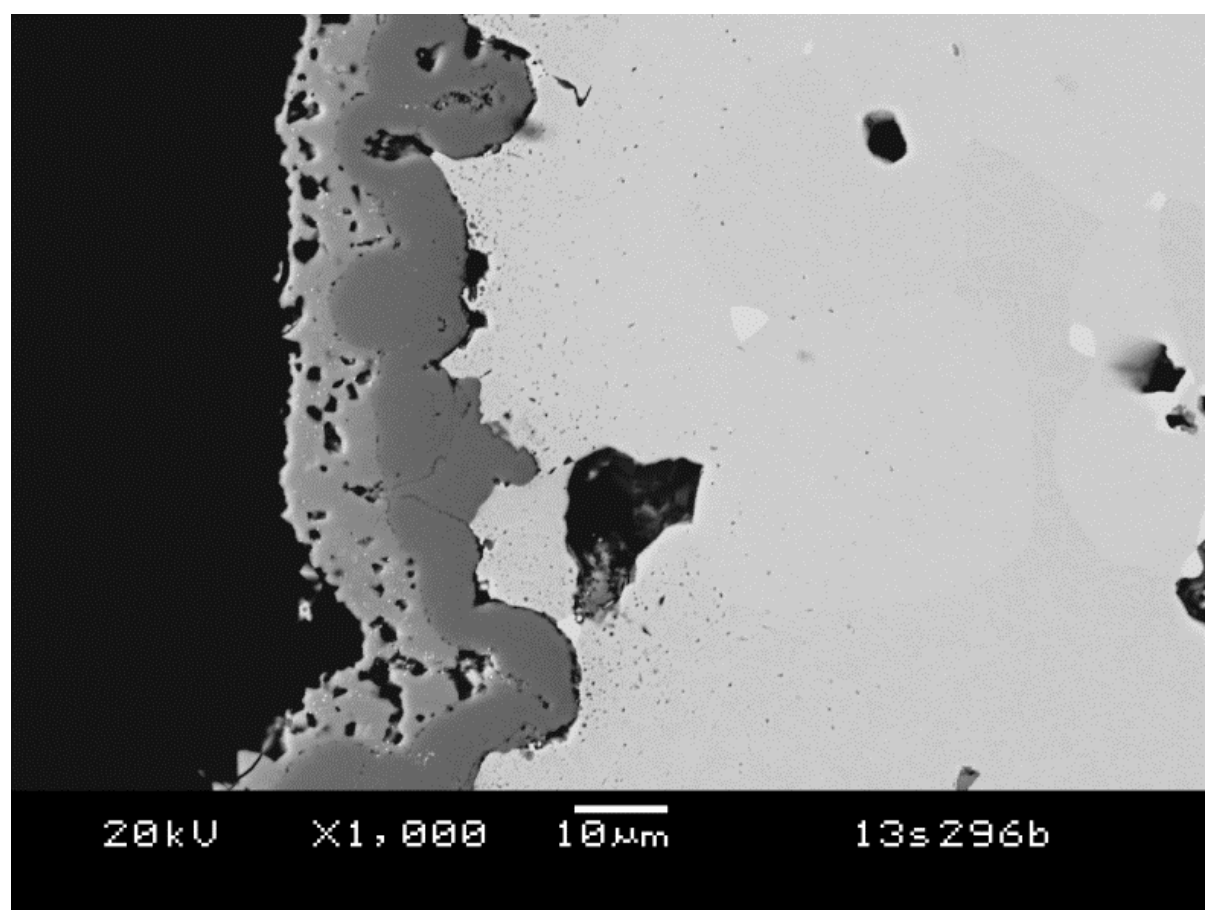

Figure 1. Cross-section SEM image of surface blasted, spinel-coated AISI 441 after 30,000 hours of oxidation in air at $800^{\circ} \mathrm{C}$.

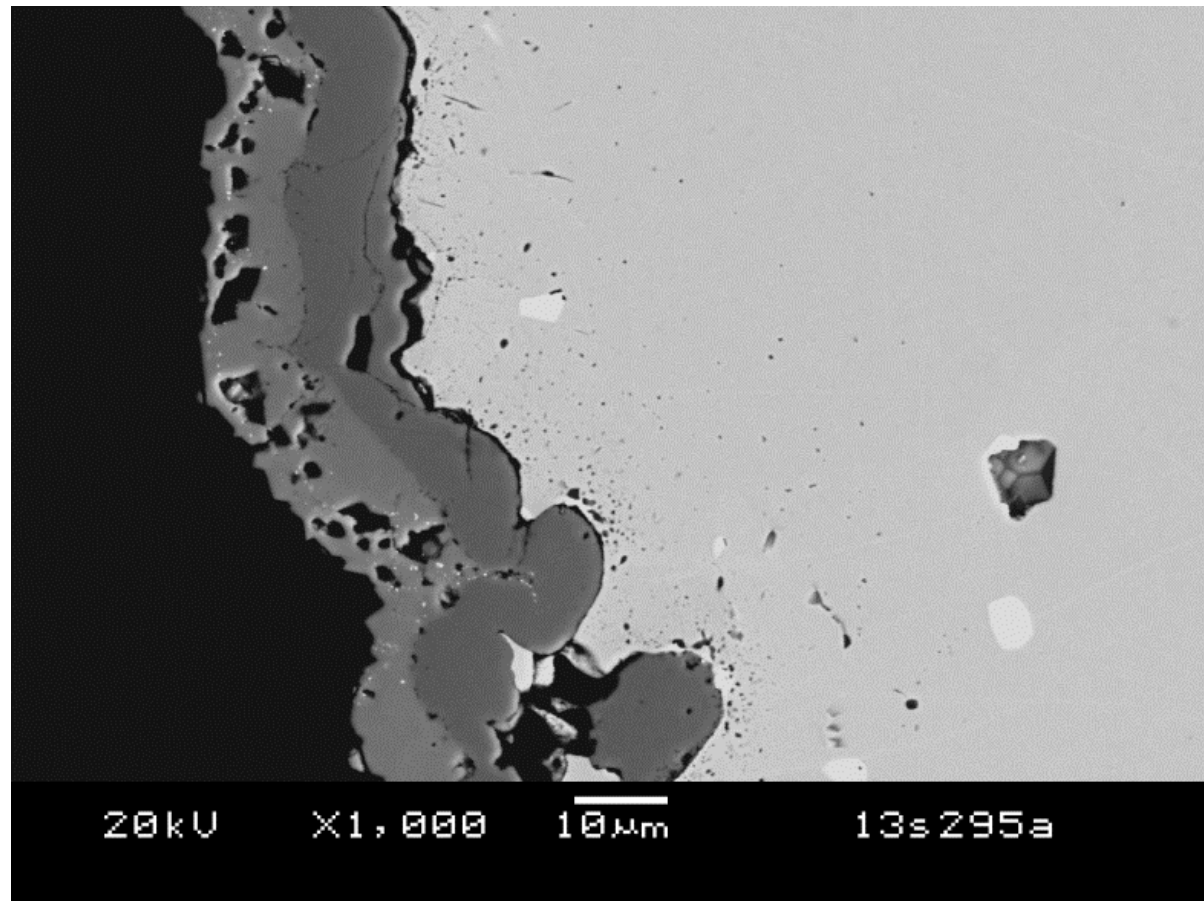

Figure 2. Cross-section SEM image of surface ground, spinel-coated AISI 441 after 30,000 hours of oxidation in air at $800^{\circ} \mathrm{C}$. 


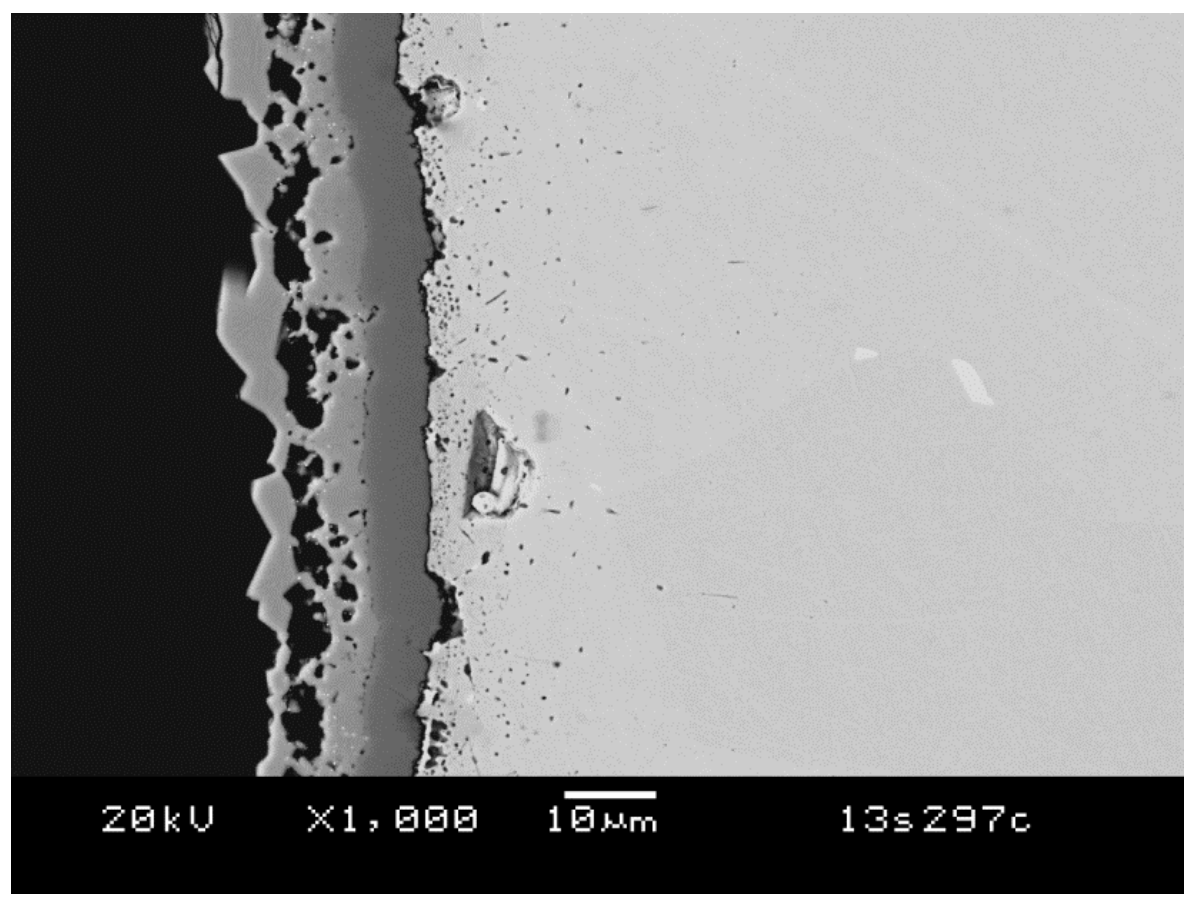

Figure 3. Cross-section SEM image of de-siliconized, spinel-coated AISI 441 after 30,000 hours of oxidation in air at $800^{\circ} \mathrm{C}$.

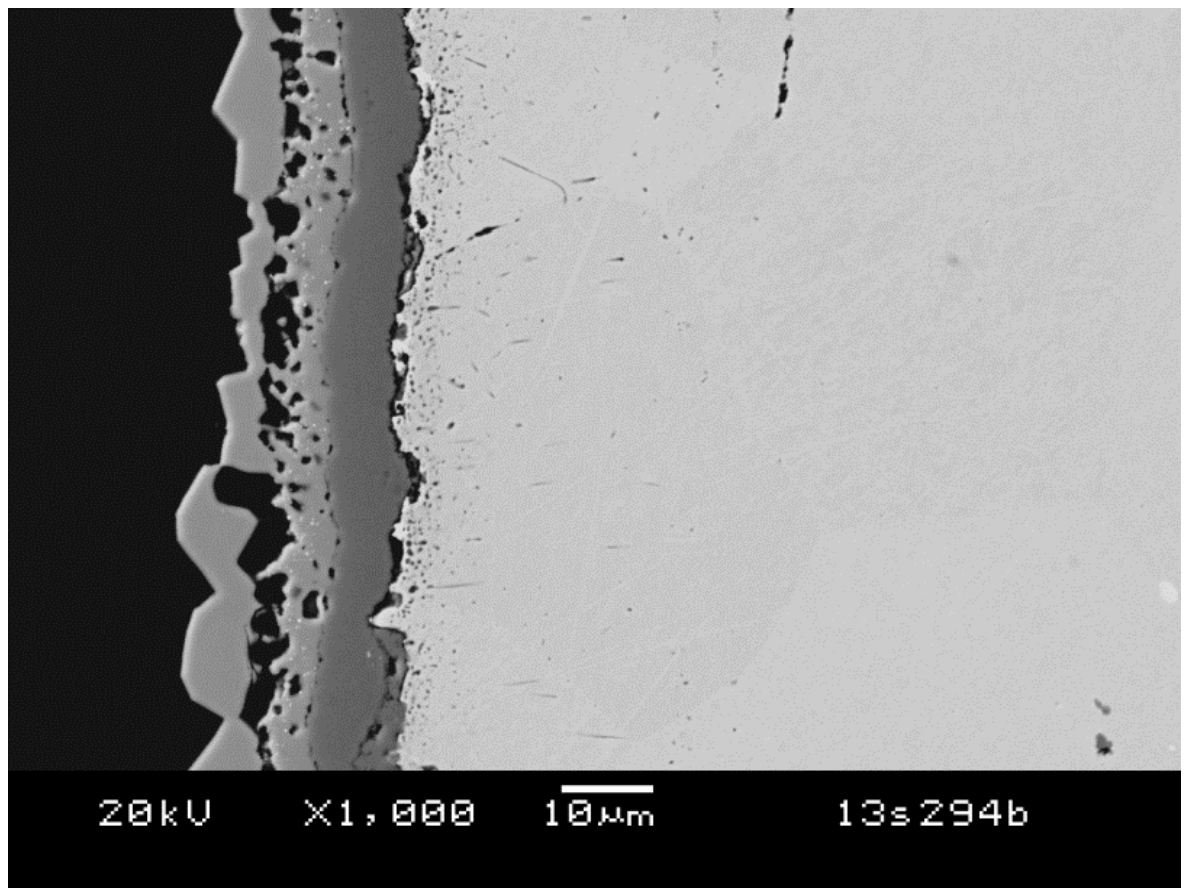

Figure 4. Cross-section SEM image of cold rolled, spinel-coated AISI 441 after 30,000 hours of oxidation in air at $800^{\circ} \mathrm{C}$. 
Surface treated $441 \mathrm{w} /$ coating; $800^{\circ} \mathrm{C}$

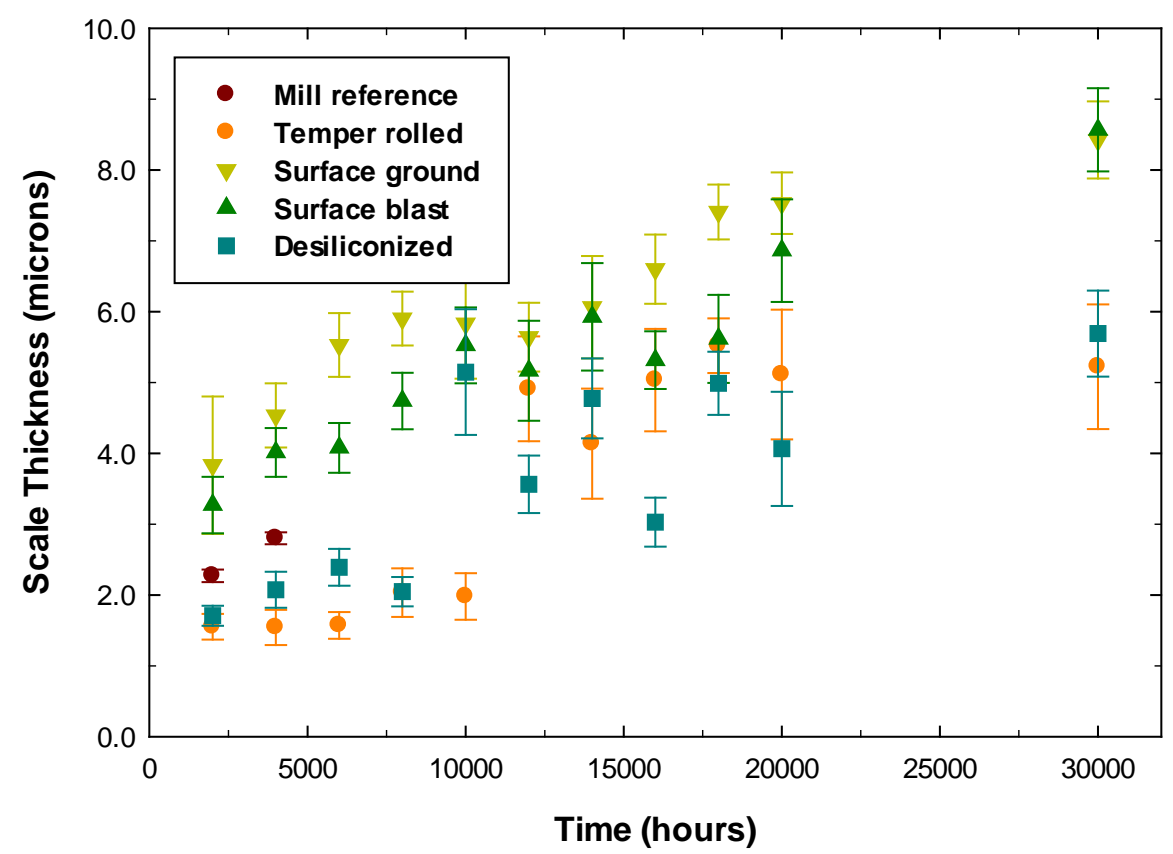

Figure 5. Average scale thickness as a function of time for coupons oxidized at $800^{\circ} \mathrm{C}$.

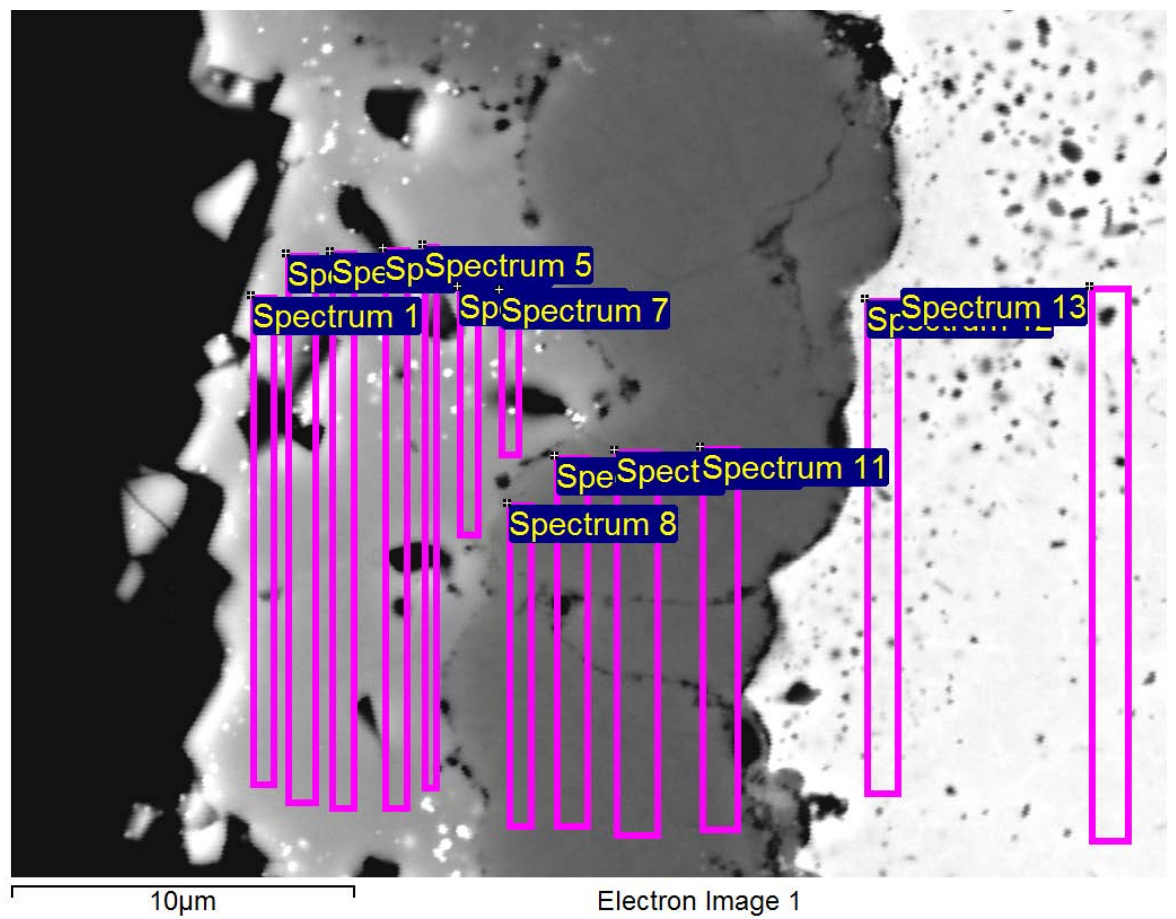

Figure 6. SEM/EDS analysis of surface blasted, spinel-coated AISI 441 after 30,000 hours of oxidation in air at $800^{\circ} \mathrm{C}$. EDS results for the indicated regions are listed in Table I. 


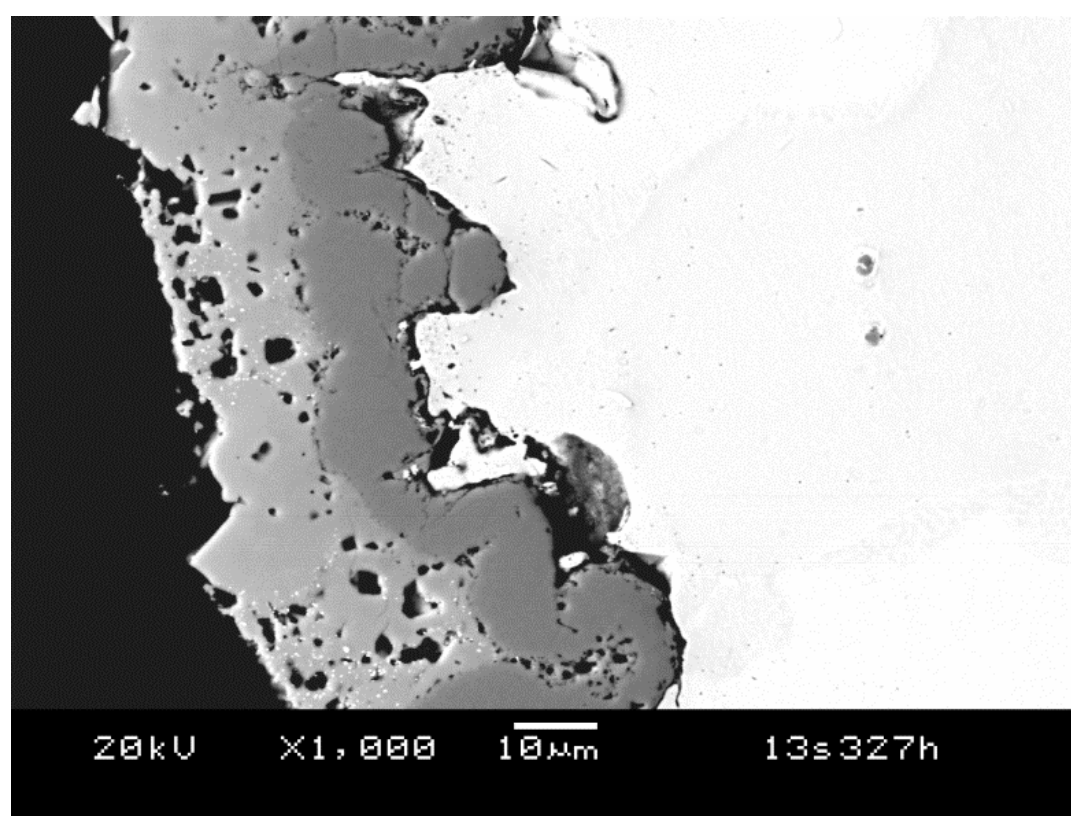

Figure 7. Cross-section SEM image of surface blasted, spinel-coated AISI 441 after 26,000 hours of oxidation in air at $850^{\circ} \mathrm{C}$.

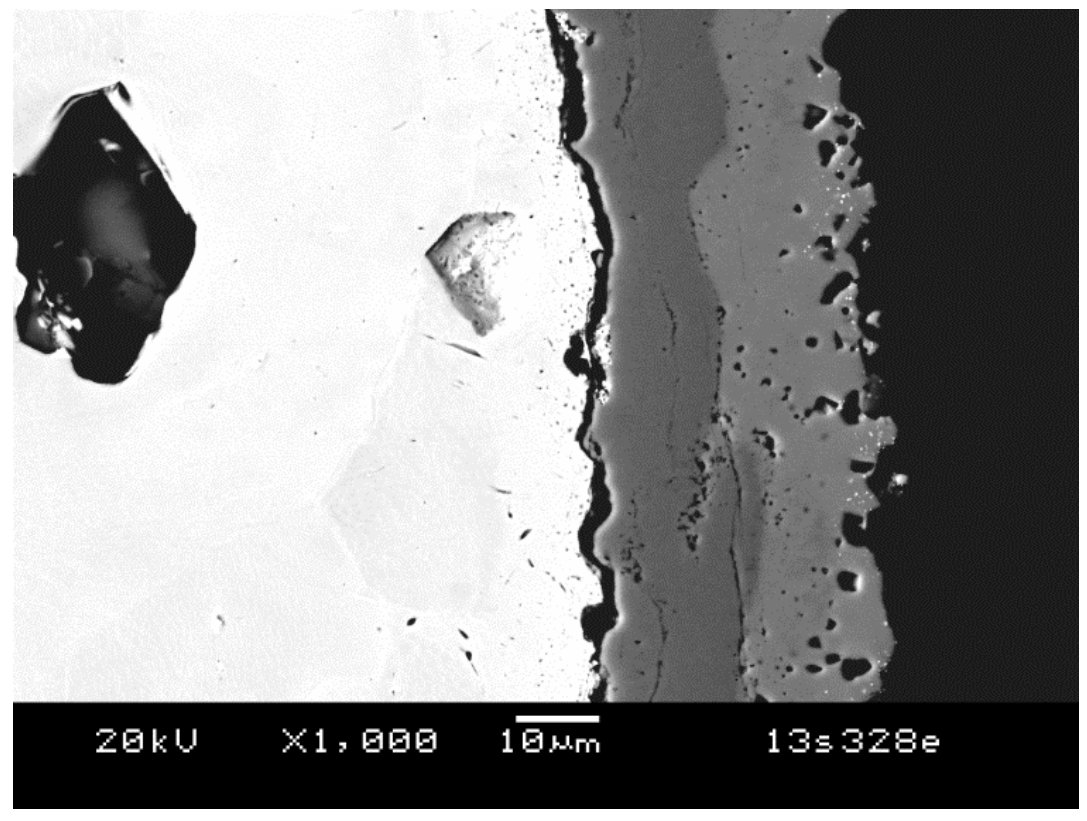

Figure 8. Cross-section SEM image of surface ground, spinel-coated AISI 441 after 26,000 hours of oxidation in air at $850^{\circ} \mathrm{C}$. 


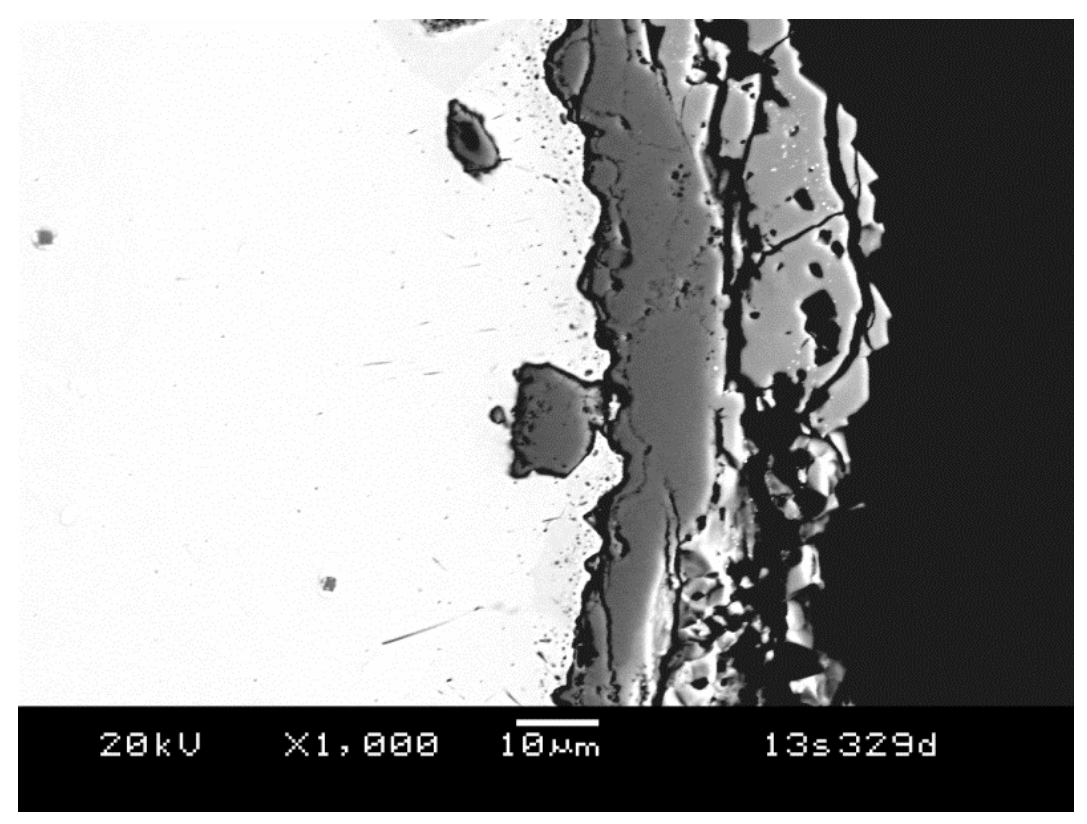

Figure 9. Cross-section SEM image of cold rolled, spinel-coated AISI 441 after 26,000 hours of oxidation in air at $850^{\circ} \mathrm{C}$.

Surface Treated $441 \mathrm{w} /$ spinel coating; $850^{\circ} \mathrm{C}$

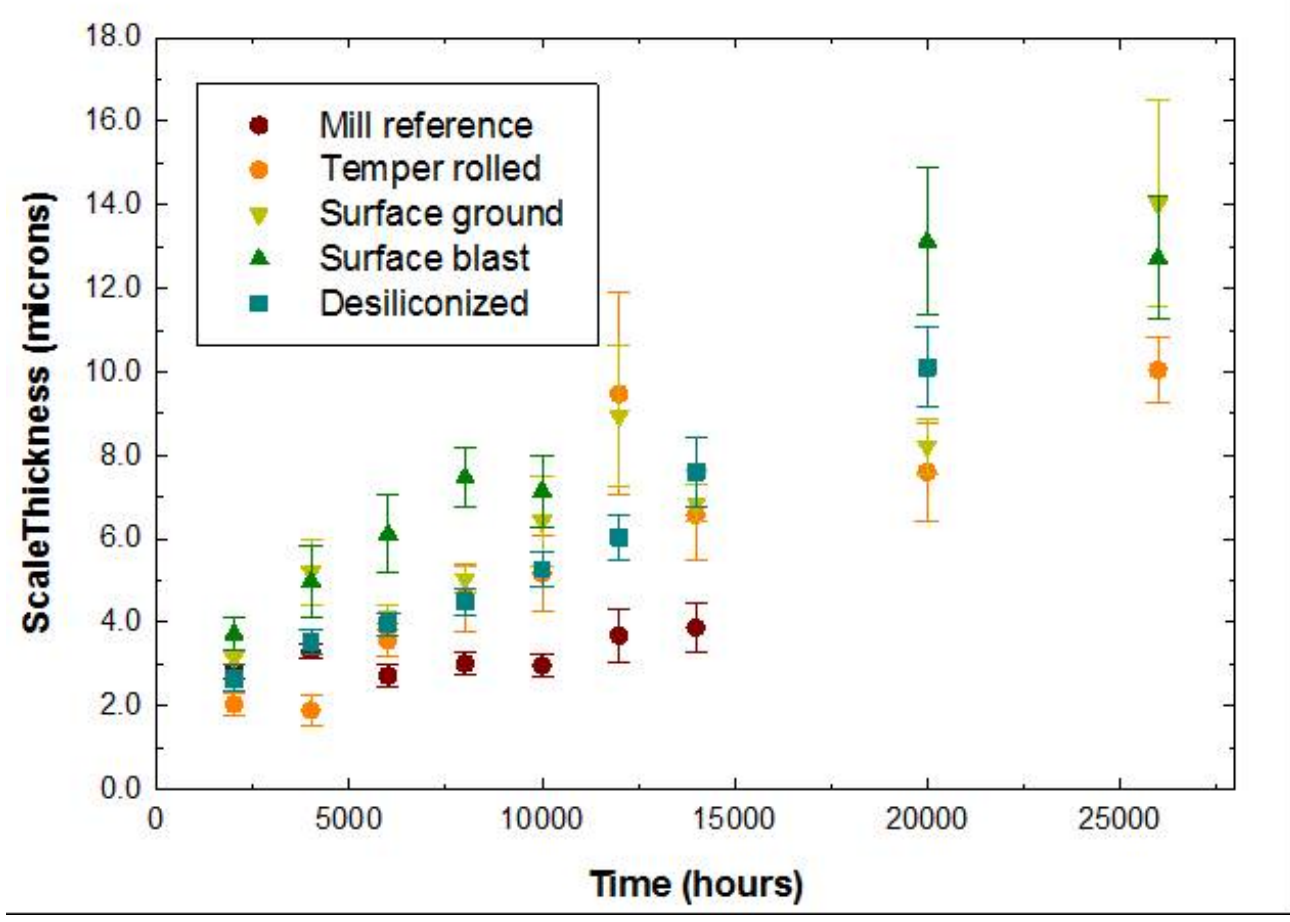

Figure 10. Average scale thickness as a function of time for coupons oxidized at $850^{\circ} \mathrm{C}$. 


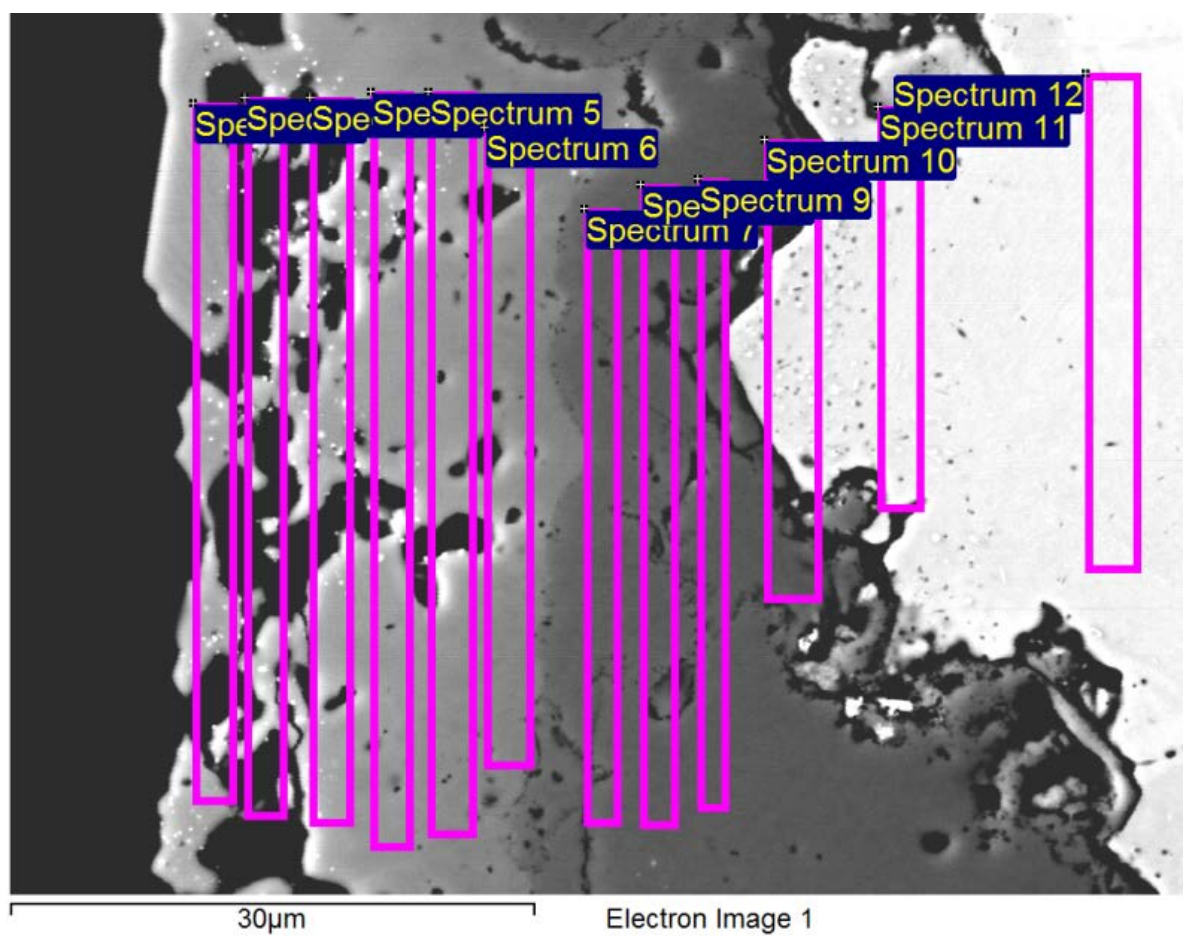

Figure 11. SEM/EDS analysis of surface blasted, spinel-coated AISI 441 after 26,000 hours of oxidation in air at $850^{\circ} \mathrm{C}$. EDS results for the indicated regions are listed in Table III. 
Optimization of Protective Coatings

Area Specific Resistance Tests [PNN and FCM powder]

Results of long-term area-specific resistance tests at $800^{\circ} \mathrm{C}$ for spinel coatings prepared from PNNL-prepared powder and Fuel Cell Materials powder are shown in Figures 1 and 2, respectively. In both cases, ASR tends to decrease with increasing coating thickness.

Area Specific Resistance Test [Metal Precursor]

To eliminate the need for a reducing atmosphere heat treatment, mixtures of $\mathrm{Mn}$ and Co powders are being considered as precursor materials for fabrication of protective spinel interconnect coatings (instead of spinel powder precursors). Details regarding the precursor preparation process are shown in Table I. As reported in the previous report, only samples of \#1, \#3, and \#5 were included in the ASR test, because the others exhibited inhomogeneous coating composition. ASR results are shown in Figure 3. After 12,000 hours at $800^{\circ} \mathrm{C}$, all of the samples had an ASR of $\sim 20 \mathrm{~m} \Omega * \mathrm{~cm}^{2}$.

Table I. Coating material preparation and each average size

\begin{tabular}{cccccc} 
& Mn & Co & Mn size & Co size & average \\
\hline$\# 1$ & Ori & Ori & 13 & 7 & 10 \\
$\# 2$ & Ori & Spex & 13 & 42.2 & 27.6 \\
$\# 3$ & Spex & Ori & 4.5 & 7 & 5.75 \\
$\# 4$ & Spex & Spex & 4.5 & 42.2 & 23.35 \\
$\# 5$ & \multicolumn{2}{c}{ Spex together } & & & 27.7 \\
\hline
\end{tabular}




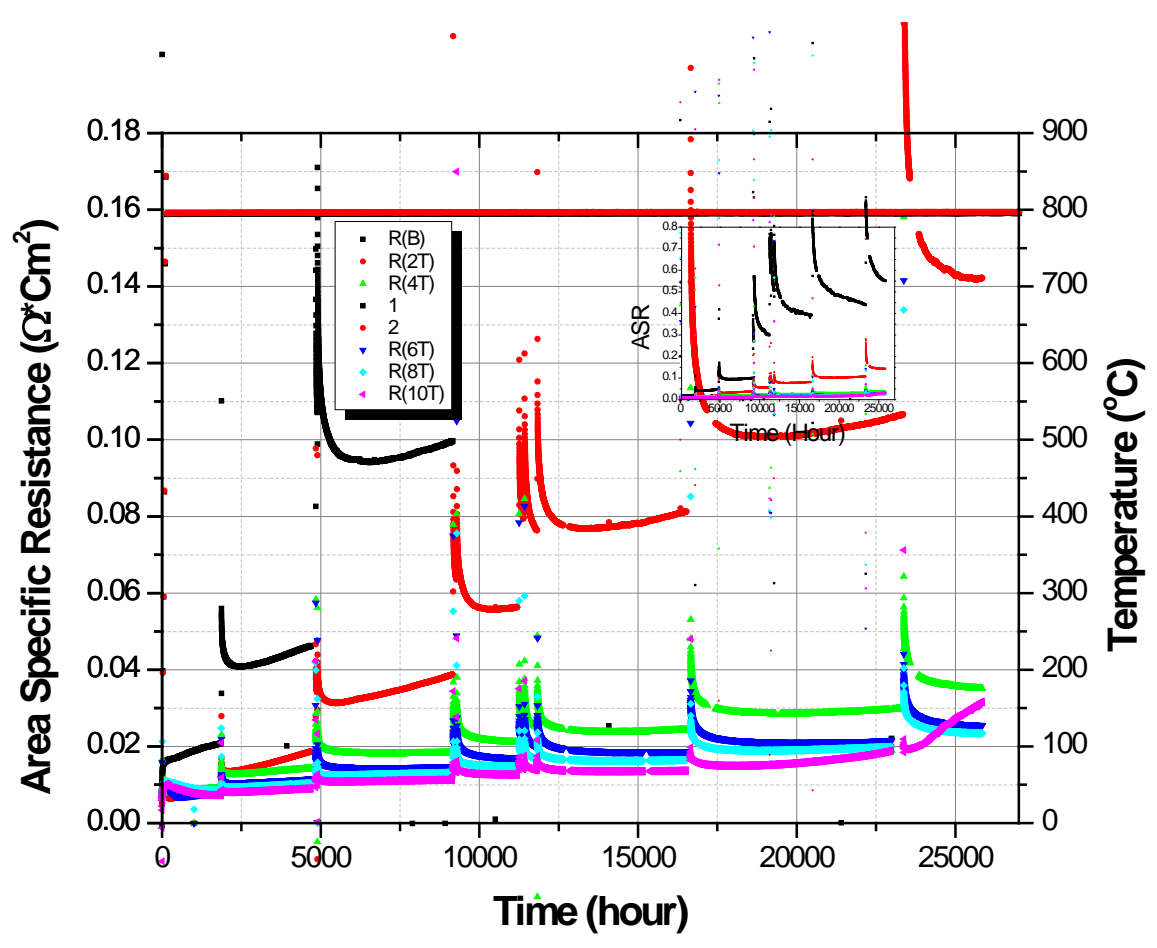

Figure 1. The ASR of uncoated SS441 and coated samples of various thicknesses. [PNNL-material]

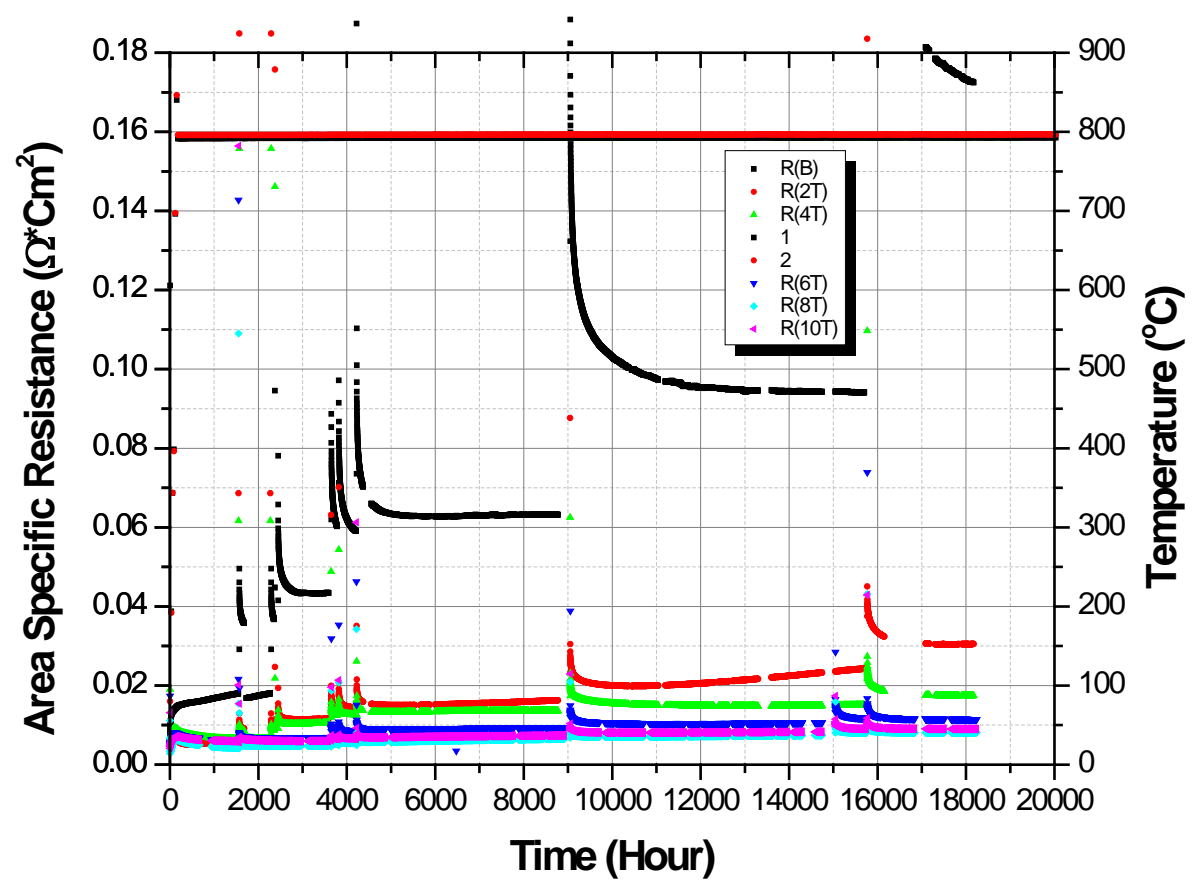

Figure 2. The ASR of uncoated SS441 and coated samples of various thicknesses. [FCE-material] 


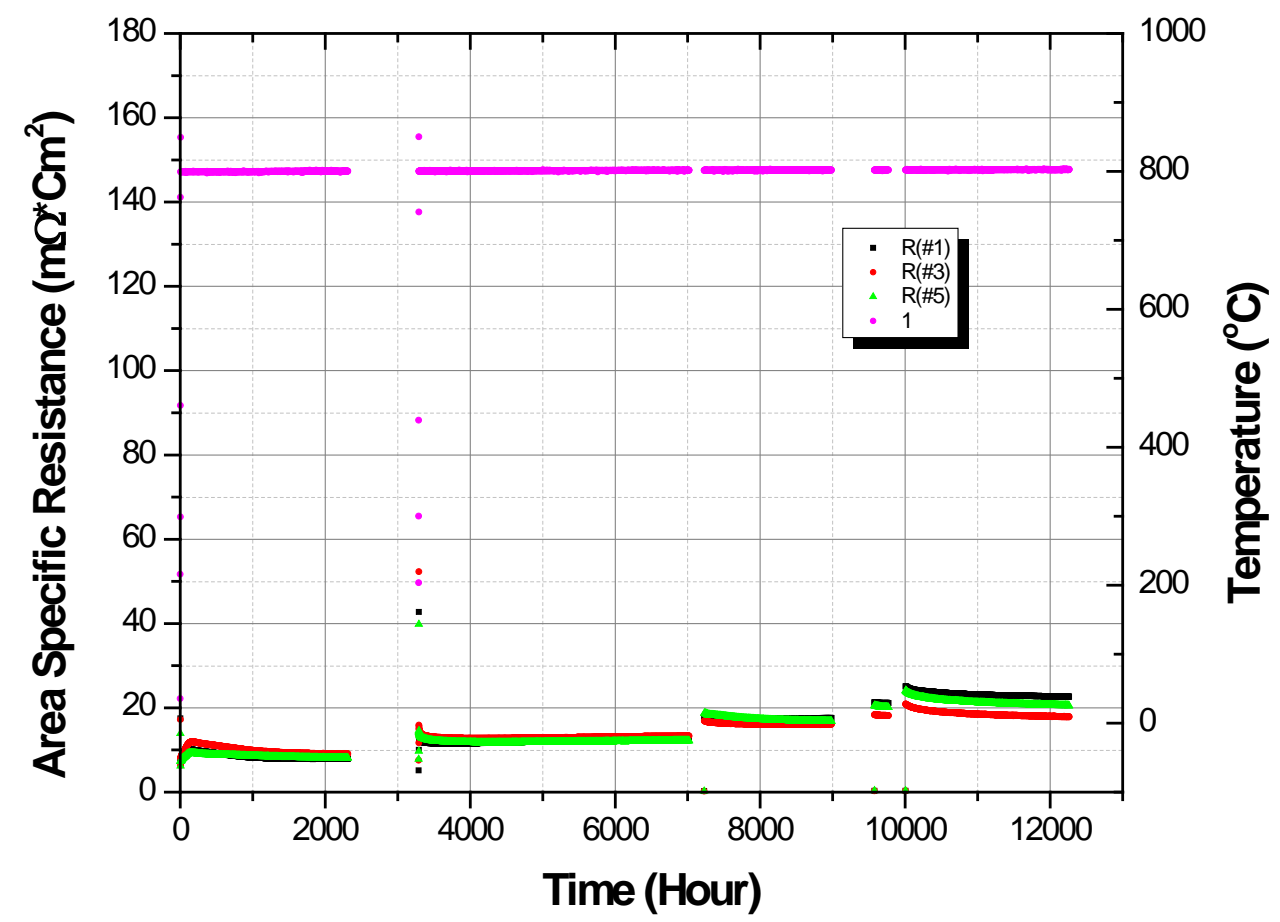

Figure 3. The ASR of uncoated SS441 and SS441 coated using metal precursor samples. 


\section{Stack Test Fixture (Matt Chou, Jung-Pyung Choi)}

Milestone: Perform base-line testing of Fuel Cell Materials anode-supported LSCF-based cell in CTP stack test fixture.

Status: Completed

Summary:

In the first quarter of FY14, base-line testing of Fuel Cell Materials' anode-supported LSCF-based cell at $800^{\circ} \mathrm{C}$ in constant current mode was completed. Two duplicate cells were tested (\#150,\#151); cell \#150 was terminated at 700h due to hydrogen generator failure. Cell \#151 showed much higher maximum power density $\left(720 \mathrm{~mW} / \mathrm{cm}^{2}\right)$ compared to Cell \#150 (526 $\left.\mathrm{mW} / \mathrm{cm}^{2}\right)$; however, it also showed large degradation in the first $250 \mathrm{~h}$ of operation $(48 \% / \mathrm{kh}$ at high current density of $625 \mathrm{~mA} / \mathrm{cm}^{2}$ ). At a lower current density of $500 \mathrm{~mA} / \mathrm{cm}^{2}$, the degradation was smaller, $18 \% / \mathrm{kh}$, which was similar to cell $\# 150(17 \% / \mathrm{kh})$. This performance was also comparable to a previous test of an H.C. Starck cell $(16 \% / \mathrm{kh})$. In other work, long-term evaluation of surface-blasted, spinel-coated AISI 441 at $800^{\circ} \mathrm{C}$ for $6000 \mathrm{~h}$ was completed. A cell (\#140) blasted with coarse grit (\#40) showed better performance with a smaller degradation rate of $1.1 \% / \mathrm{kh}$ than a fine-grit (\#80) blasted cell (\#139), which degraded at $4.7 \% / \mathrm{kh}$ in the last $\sim 1000 \mathrm{~h}$ of running. Post-mortem analysis was conducted and showed hermetic seal for the surface-blasted cells. Results of microstructure analysis will be reported in the next report. Also, a long-term stack fixture evaluation of compliant type sealing glass with $\mathrm{ZrO}_{2}$ fibers was still running at the time of this report. The details of the first quarter work are discussed below.

\section{Stack Fixture Tests at PNNL}

(1) Base-line testing of Fuel Cell Materials' anode-supported LSCF-based cell at $800^{\circ} \mathrm{C}$

In the first quarter of FY14, base-line testing of LSCF-based cells from Fuel Cell Materials (FCM) was performed to establish the basic performance data. The domestically produced cell was selected to allow for comparison with previously tested H.C. Starck's ASC-4 cell, which is manufactured in Germany, and to evaluate its potential as the host cell for cathode infiltration work. FCM's LSCF-based cell is similar to Starck's LSCF-based cell in that it is a $\mathrm{NiO} / \mathrm{YSZ}$ anode-supported thin YSZ electrolyte cell of $5 \mathrm{~cm}$ x $5 \mathrm{~cm}$ size with an active cathode area of $4 \mathrm{~cm} \mathrm{x} 4 \mathrm{~cm}$. FCM's cell has a much thinner NiO-YSZ anode support (220-260 $\mu \mathrm{m})$, which is about half the thickness of the Starck cell. The cathode is LSCF/LSCF-GDC of $\sim 50 \mu \mathrm{m}$ thickness, and the YSZ electrolyte is $\sim 10 \mu \mathrm{m}$ thick. Due to the thinner anode support, the FCM cell was slightly warped, which may result in unevenness in glass seals and contact materials. The FCM cells were sealed onto aluminized AISI441 cell frame plates, heated to $930-950^{\circ} \mathrm{C} / 2 \mathrm{~h}$ and tested for hermeticity before being included in the cell test assembly. The initial electrochemical performance data of Cell \#151 in terms of impedance and I-V sweep (before a stability test for $\sim 1000 \mathrm{~h}$ ) is shown in Figure $1 \mathrm{~A}$ and $1 \mathrm{~B}$, respectively. Note that data from last quarter's FCM cell (\#150) and a previously tested Starck LSCF-based cell are also included. The duplicate FCM cell (\#151) showed much smaller impedance, especially in the polarization portion (Figure 1A), and the maximum power density increased to $720 \mathrm{~mW} / \mathrm{cm}^{2}$ from the previous value of $526 \mathrm{~mW} / \mathrm{cm}^{2}$. In comparison, the Starck cell had a maximum power density of $\sim 520 \mathrm{~mW} / \mathrm{cm}^{2}$. After the initial impedance and I-V sweep analysis, cell performance stability was evaluated in constant current mode using dilute hydrogen fuel $\left(\mathrm{H}_{2}: \mathrm{N}_{2}=1: 1\right.$ with $\left.\sim 3 \% \mathrm{H}_{2} \mathrm{O}\right)$ 
and air at $800^{\circ} \mathrm{C}$. Cell voltage versus time is plotted in Figure 2. The first FCM cell (\#150) was terminated after $\sim 700 \mathrm{~h}$ due to a hydrogen generator failure that resulted in anode re-oxidation and subsequent cell fracture. The second FCM cell (\#151) was still under test at the time of this report. This cell was tested at a current density of $625 \mathrm{~mA} / \mathrm{cm}^{2}$ (total of 10A) during the first $\sim 250 \mathrm{~h}$, which resulted in a high degradation rate of $\sim 49 \% / \mathrm{kh}$. The cell was then tested at a slightly lower current density of $500 \mathrm{~mA} / \mathrm{cm}^{2}$ (total of $8 \mathrm{~A}$ ), resulting in a lower degradation rate of $\sim 18 \% / \mathrm{kh}$. This is similar to the degradation rate of the first FCM cell of $\sim 18 \% / \mathrm{kh}$ (at 500 $\mathrm{mA} / \mathrm{cm}^{2}$ ) as well as to the $\sim 16 \% / \mathrm{kh}$ observed with the Starck ASC-4 cell (at $488 \mathrm{~mA} / \mathrm{cm}^{2}$ ). Impedance spectra were recorded for Cell \#151 at different time intervals, as shown in Figure 3A and $3 \mathrm{~B}$ for the whole spectrum and with differentiation between ohmic and polarization contributions, respectively. It is clear that both the ohmic and polarization components contributed to the cell's degradation. Impedance versus time ${ }^{\wedge} 0.5$ is plotted in Figures $4 \mathrm{~A}$ and $4 \mathrm{~B}$ for Cell \#151 and Cell \#150, respectively. Both the ohmic and polarization parts exhibited a linear relationship with similar coefficients, suggesting similar degradation mechanisms for the two cells. Comparing to previous tests on LSM-based cells, it is evident that the more active LSCF-based cells degraded much faster (about 10 times higher degradation rate), and can greatly reduce the advantages of initially high power density. The long-term degradation of LSCF-based cells remains to be determined, and root cause needs to be identified before improvement can be applied or tested. Overall, the FCM LSCF-based cell showed similar electrochemical performance to Starck cells.

\section{(2) Long-term evaluation of surface-blasted spinel-coated AISI441 interconnect}

The long-term evaluation of surface-blasted, spinel-coated AISI441 interconnects in stack fixture tests was recently completed. Cell \#140 and cell \#139 reached $6000 \mathrm{~h}$ of testing at $800^{\circ} \mathrm{C}$ with an AISI441 interconnect surface blasted with coarse grit (\#40) and fine grit (\#80), respectively. Both cells used a standard Starck cell (ASC-3) with LSM cathode. The same contact materials and seals were used for both tests. The long-term cell voltage is plotted in Figures 5 and 6 for Cell \#139 and Cell \#140, respectively. For comparison, results for a spinelcoated AISI441 interconnect without the surface treatment are also included. In these figures the inset numbers represent the average degradation rate for every 500 or $1000 \mathrm{~h}$ in terms of $\% / \mathrm{kh}$. It is evident that the cell with fine-grit blasted AISI441 interconnect showed higher degradation rates than cell with the coarse-grit blasted interconnect. For example, the degradation rate of the cell with the fine-grit blasted interconnect was about $\sim 2-3 \% / \mathrm{kh}$ in the first $\sim 2500 \mathrm{~h}$, and increased to $\sim 5-7 \% / \mathrm{kh}$ (Figure 5). The degradation rate of the cell with a coarse-grit blasted interconnect was $\sim 1 \% / \mathrm{kh}$ in the first $\sim 3000 \mathrm{~h}$ and $\sim 2 \% / \mathrm{kh}$ for the final $\sim 3000 \mathrm{~h}$. When compared to AISI441 without surface treatment, the cell with coarse-grit blasted appeared to have similar degradation except for the final $\sim 1000 \mathrm{~h}$, in which the coarse-grit sample exhibited fairly constant behavior while accelerated degradation was observed for the as-received AISI441 interconnect (Figure 6). Impedance of the cell with a coarse grit (\#40) blasted interconnect was also recorded at different time intervals; results are shown in Figure 7A for individual contributions versus time, and in Figuire $7 \mathrm{~B}$ for the ohmic portion versus time ${ }^{\wedge} 0.5$. Clearly the degradation of the cell was primarily from ohmic portion in that the polarization part actually showed a slightly decreasing trend (Fig. 7A). The increase of ohmic part showed a linear relationship with time ${ }^{\wedge} 0.5$, suggesting that oxide scale growth was the dominant mechanism.

After finishing the long-term $\left(800^{\circ} \mathrm{C} / \sim 6000 \mathrm{~h}\right)$ stability tests, Cells \#140 and \#139 were subjected to $\sim 10$ deep thermal cycles. The objective of the deep thermal cycling was to impose residual stresses and then to see if spallation of oxide scale occurred; in previous work, stress 
modelling and tests on small coupons have demonstrated the benefit of surface treatment. If uniform spallation occurred, one should detect changes in the ohmic component from impedance analysis, since the Cr-oxide scale spallation or de-bonding from the underlying metal substrate would lead to some loss of electrical contact. Figure 9 shows the cell impedance spectrum versus number of thermal cycles for Cell \#140 and Cell \#139 in Figures 9A and 9B, respectively. The change in ohmic resistance (first intersect with $\mathrm{x}$-axis) in both cells appeared to be very small, which suggests that there was no major spallation of oxide scale. In previous work, standalone small coupon tests of surface-blasted, spinel-coated AISI441 showed no macro- or microspallation after $>20,000 \mathrm{~h}$ at $800^{\circ} \mathrm{C}$ in ambient air. Clearly, this long-term stack fixture test did not approach that time scale, but the results of the test clearly gave no indication of any negative effects on performance due to the surface treatment of AISI441 interconnects.

Post-mortem analysis was conducted after completion of the test. Results of optical microscopy are presented in this report. Detailed microstructural analysis will be reported in the next progress report. Upon completion of the long-term test, both cells were first subjected to a leak check when cooled to room temperature with only one type of gas flowing, i.e., either air or fuel at the normal flow rate. Both cells showed no cross-bubbling, indicating hermetic sealing. The cells were then carefully dis-assembled. Figure 10 shows the mating surfaces of the anode side on the metal interconnect (Figure 10A) and of the cell (Figure 10B) from cell \#140 (grit \#40). Figure 11 shows the cathode side. No evidence of leakage (e.g., discoloration of component surfaces) was found. Cell \#139, which was surface-blasted with fine-grit \#80, had similar features and is therefore not shown.

\section{(3) Long-term evaluation of engineered compliant glass ( $\mathrm{SCN}-1$ with $15 \% \mathrm{ZrO}_{2}$ fibers)}

In the first quarter of FY14, a long-term evaluation of an engineered compliant glass seal (with $15 \mathrm{v} \% \mathrm{ZrO}_{2}$ fibers) continued (Stack fixture test \#144). A Starck LSM-based cell (ASC-3) was tested at $800^{\circ} \mathrm{C}$ in constant current mode. Figure 12 shows the cell performance in terms of voltage versus time. For comparison, the performance of a cell with refractory glass seals is also included (all the materials in the tests were the same except for the sealing glass). Note that cell $\# 144$ was initially subjected to three deep (from $800^{\circ} \mathrm{C}$ to $\sim 50^{\circ} \mathrm{C}$ ) thermal cycles after every $500 \mathrm{~h}$ of testing to check the integrity of the cell to frame seal; no evidence of leakage (e.g., from crossbubbling of gases) was observed. This cell was later selected for the long-term test. The cell suffered some damage around $1750 \mathrm{~h}$ due to a power outage during which time air flow and compressive loading on the cell were lost; some furnace cooling also occurred. The sudden change in gas environment and stress may have attributed to the rapid increase in ohmic resistance from $\sim 0.02 \mathrm{ohm}$ to $\sim 0.04 \mathrm{ohm}$, which led to the drop in cell voltage. The increase in ohmic resistance was likely due to some loss of contact. During the same time frame, the polarization component remained fairly constant at $\sim 0.04 \mathrm{ohm}$. The cell test is now at $\sim 5500 \mathrm{~h}$; the test will be terminated after $6000 \mathrm{~h}$ and the cell will be subjected to microstructure analysis. Judging from the cell's voltage performance in the last $\sim 2300 \mathrm{~h}$ data (from $\mathrm{t}=3248 \mathrm{~h}$ to $\mathrm{t}=5511 \mathrm{~h}$ ) (Figure 12,) the cell appeared to have a similar degradation rate to the cell sealed with the refractory glass. The average degradation rate for the cell with the engineered compliant glass seal was $\sim 2.3 \% / \mathrm{kh}$, while it was $\sim 2.9 \% / \mathrm{kh}$ (from $\mathrm{t}=3000 \mathrm{~h}$ to $\mathrm{t}=6000 \mathrm{~h}$ ) for the cell sealed with refractory glass. The results appear to be promising and suggest there are no distinct adverse effects due to volatilization of alkalis from the compliant glass. 

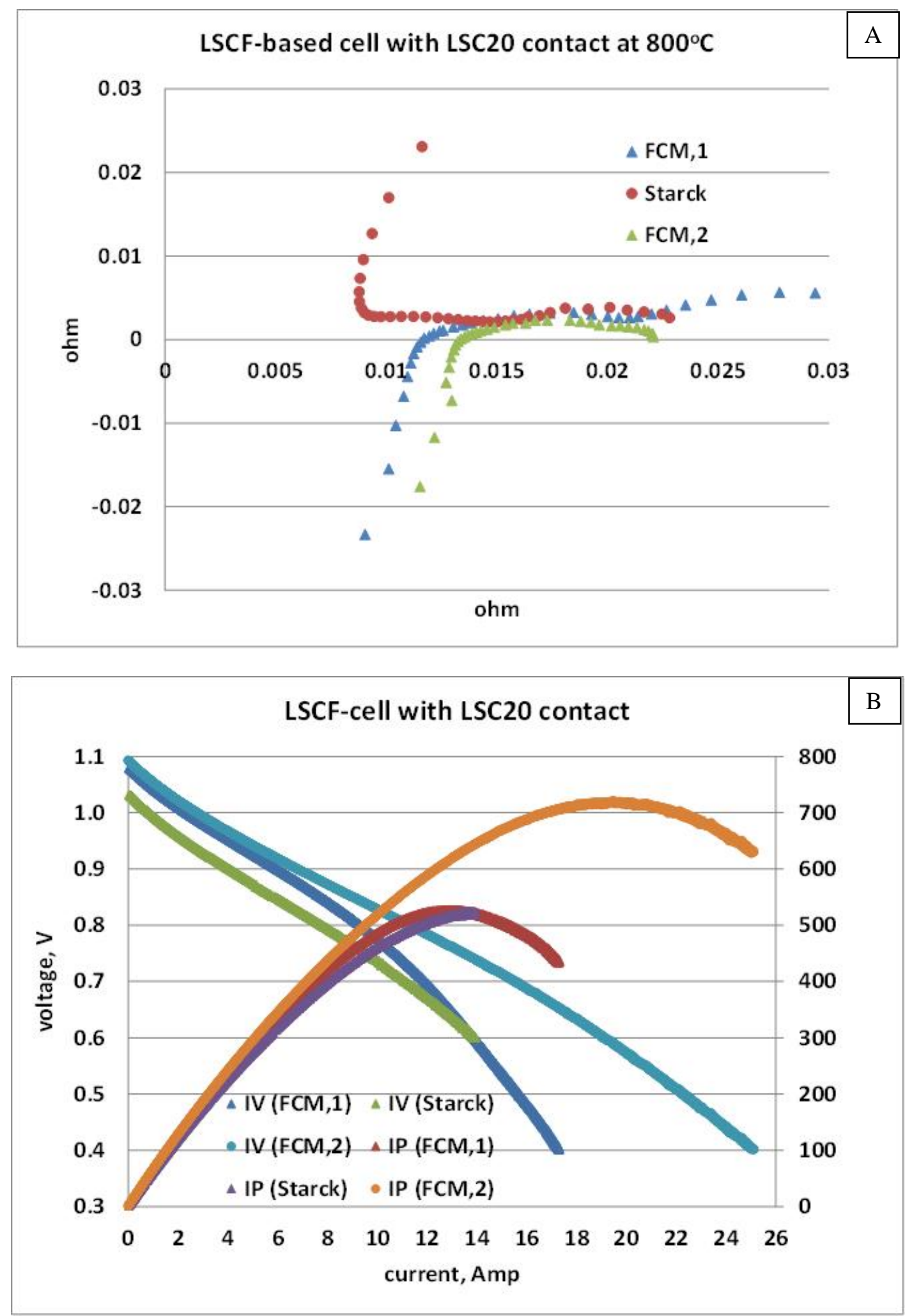

Figure 1. Electrochemical performance of Fuel Cell Materials LSCF-based cell, (A) impedance spectrum and (B) I-V sweep at $800^{\circ} \mathrm{C}$. Two duplicate cells from FCM (FCM,1 and FCM,2) were tested and compared to an LSCF-based cell from Starck (ASC-4). 


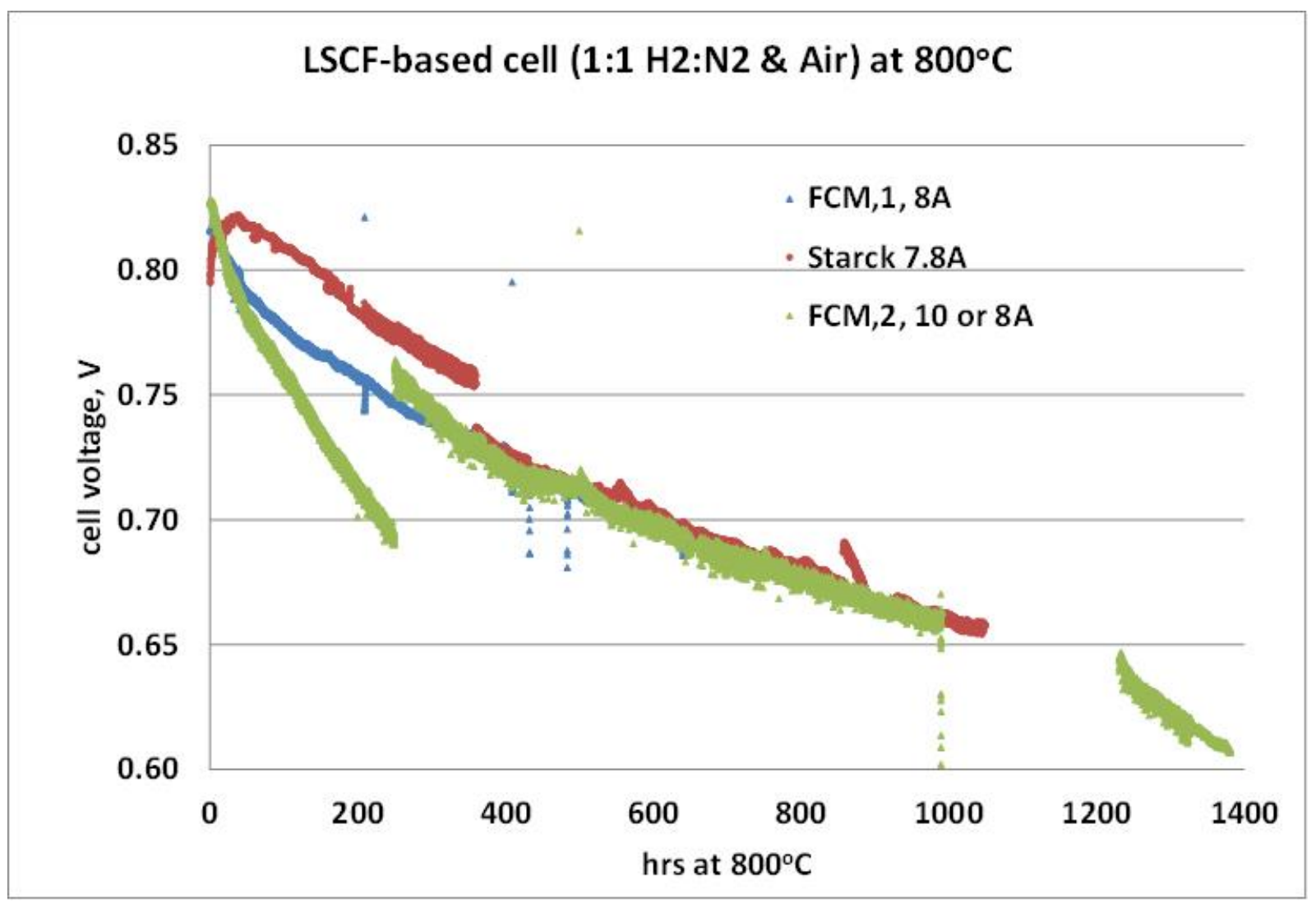

Figure 2. Base-line testing of LSCF-based cells from Fuel Cell Materials (FCM,1 = cell \#150 and FCM,2 $=$ cell \#151) with LSC as cathode contact material at $800^{\circ} \mathrm{C}$ under constant current conditions using diluted fuel of $\mathrm{H}_{2}: \mathrm{N}_{2}=1: 1$ versus air. Previous results from a cell from Starck (ASC4) are also included. All three cells showed similar degradation of $16-18 \% / \mathrm{kh}$ between $\sim 400 \mathrm{~h}$ to $\sim 1000 \mathrm{~h}$. Cell \#150 (blue) was terminated around $\sim 700 \mathrm{~h}$ due to hydrogen generator failure which resulted in re-oxidation of anode and cell fracture. Cell \#151 (green) suffered computer break down and loss of data between $\sim 1000 \mathrm{~h}$ to $\sim 1250 \mathrm{~h}$. 

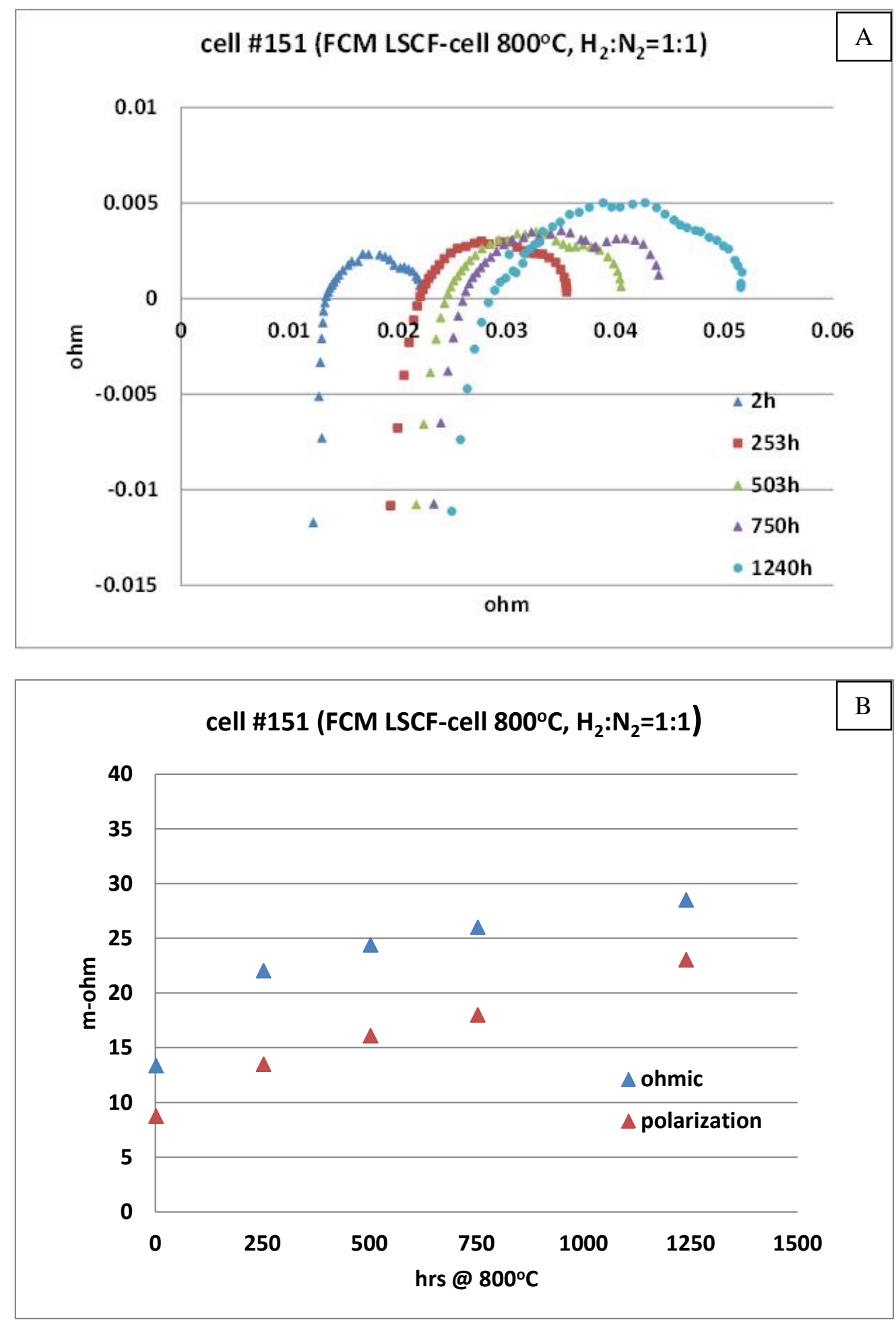

Figure 3. FCM's LSCF-based cell (Cell \#151) impedance data during stability test, (A) impedance versus time, and (B) contribution from ohmic and polarization part versus time at $800^{\circ} \mathrm{C}$. 

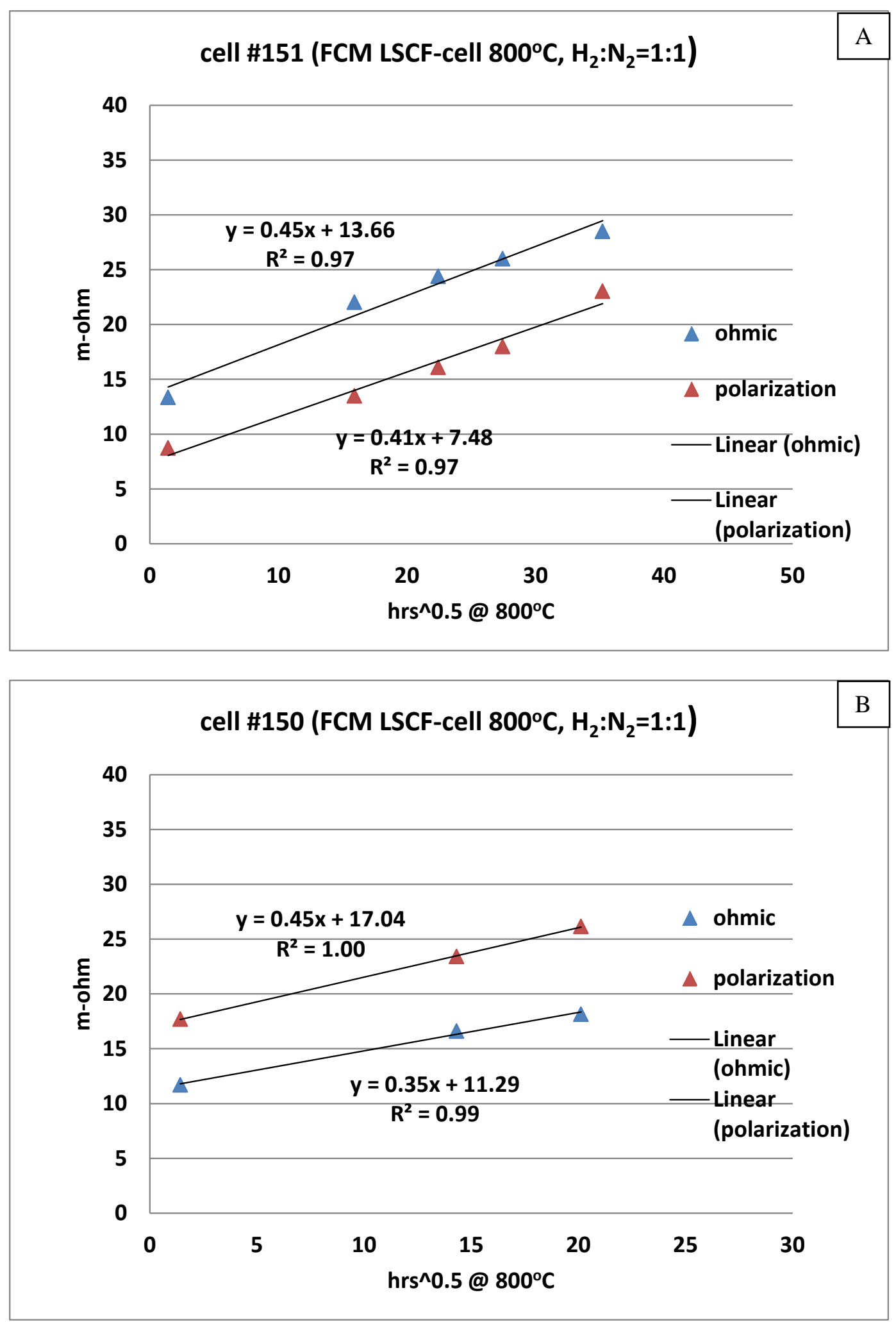

Figure 4. FCM's LSCF-based cell impedance change with time ${ }^{\wedge} 0.5$, (A) cell \#151, and (B) cell $\# 150$. 


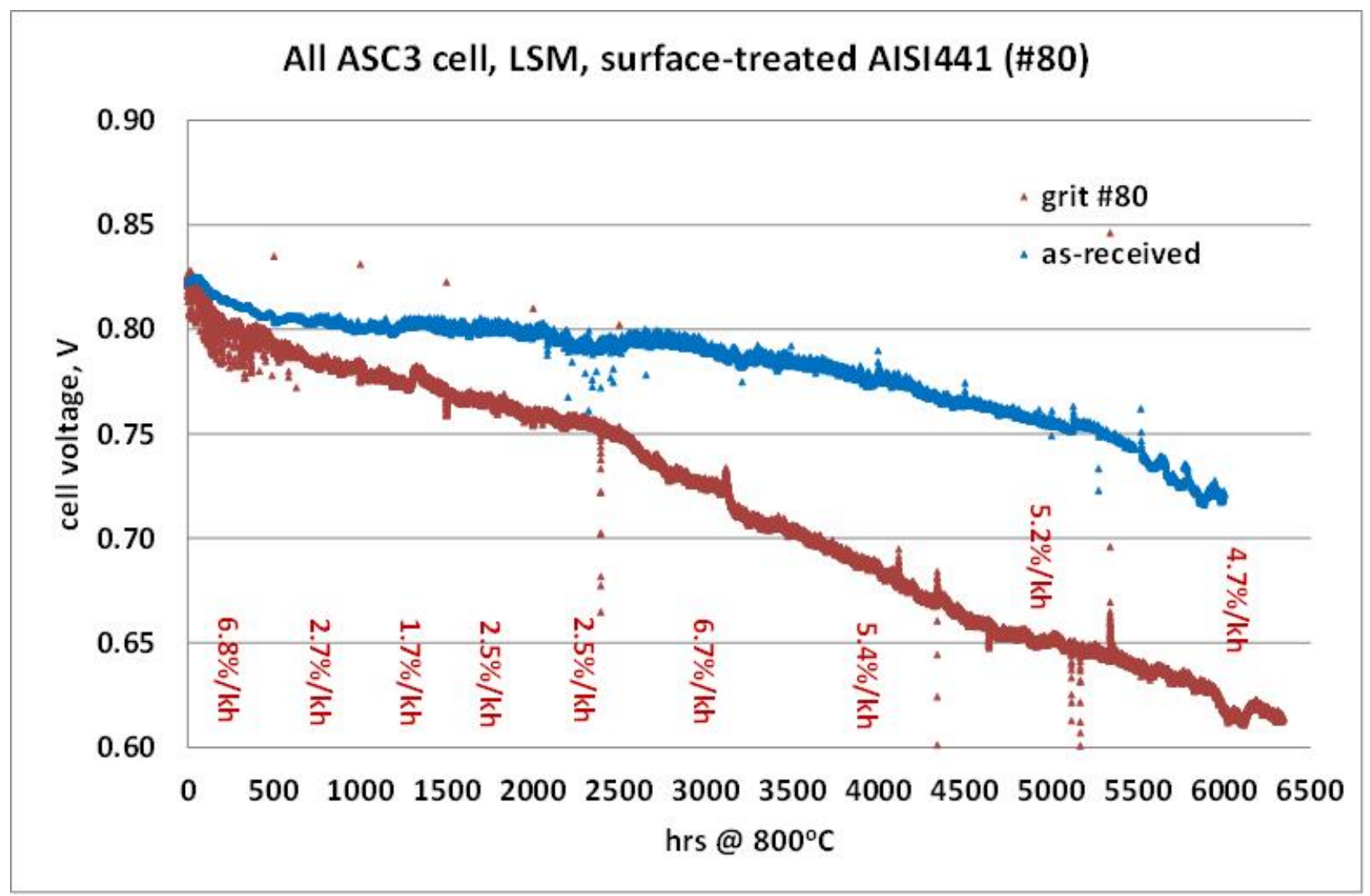

Figure 5. Validation test of surface-blasted AISI441 interconnect plate with LSM-based cell (ASC-3, \#139) in a stack fixture test at $800^{\circ} \mathrm{C}$ in constant current mode using fuel of diluted and humidified hydrogen $\left(\mathrm{H}_{2}: \mathrm{N}_{2}=1: 1\right)$ versus air. Note the AISI441 surface was blasted with grit sizes \#80 before being coated with Ce-(Mn,Co)-spinel. For comparison, the data for an ASC-3 cell without surface treatment is also included. The numbers inserted are the calculated degradation rate per $1000 \mathrm{~h}$ for every 500 or $1000 \mathrm{~h}$ running for cell \#139. 


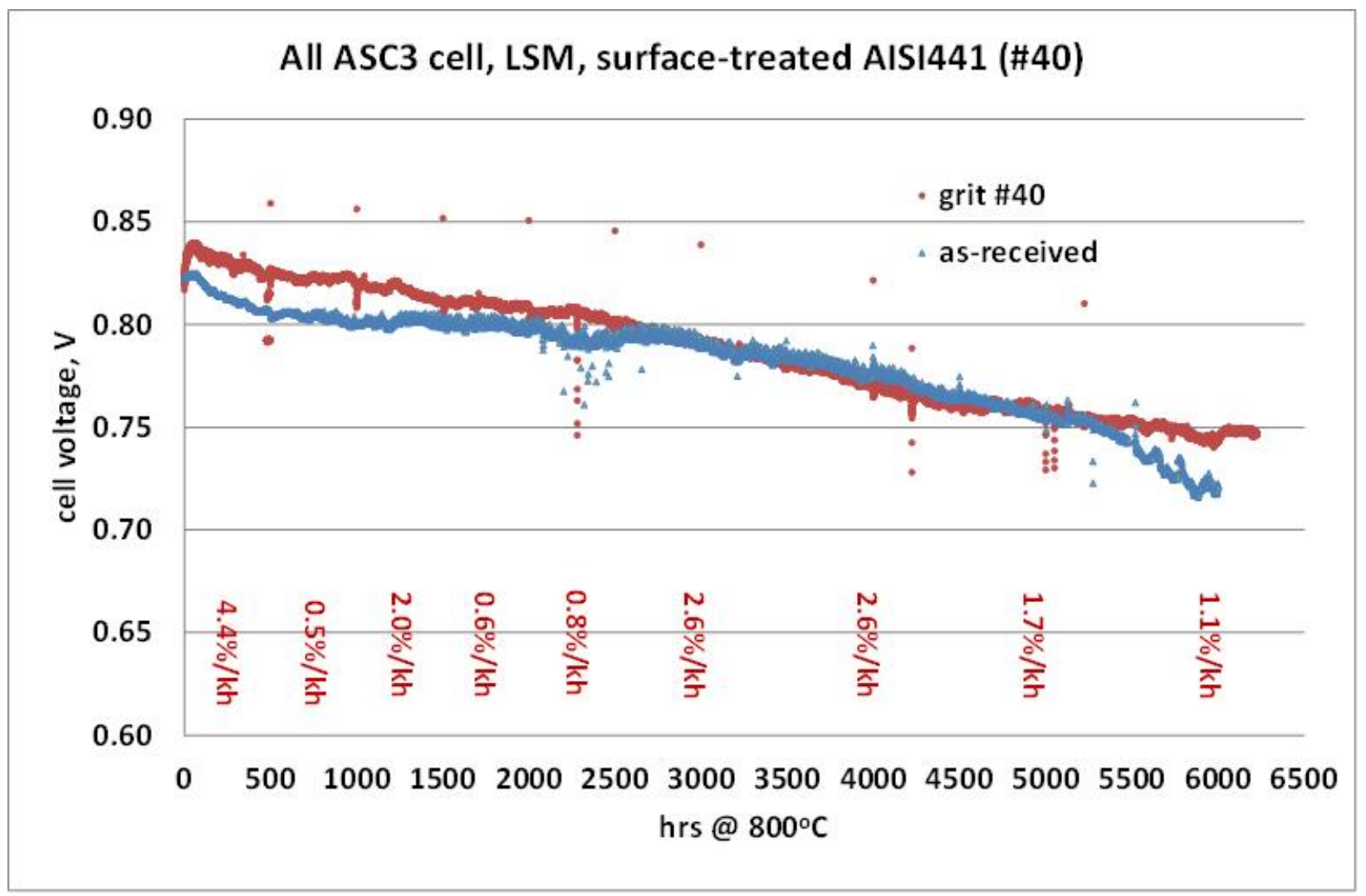

Figure 6. Validation test of surface-blasted AISI441 interconnect plate with LSM-based cell (ASC-3, \#140) in a stack fixture test at $800^{\circ} \mathrm{C}$ in constant current mode using fuel of diluted and humidified hydrogen $\left(\mathrm{H}_{2}: \mathrm{N}_{2}=1: 1\right)$ versus air. Note the AISI441 surface was blasted with grit sizes \#80 before being coated with Ce-(Mn,Co)-spinel. For comparison, the data for an ASC-3 cell without surface treatment is also included. The numbers inserted are the calculated degradation rate per $1000 \mathrm{~h}$ for every 500 or $1000 \mathrm{~h}$ running for cell \#140. 

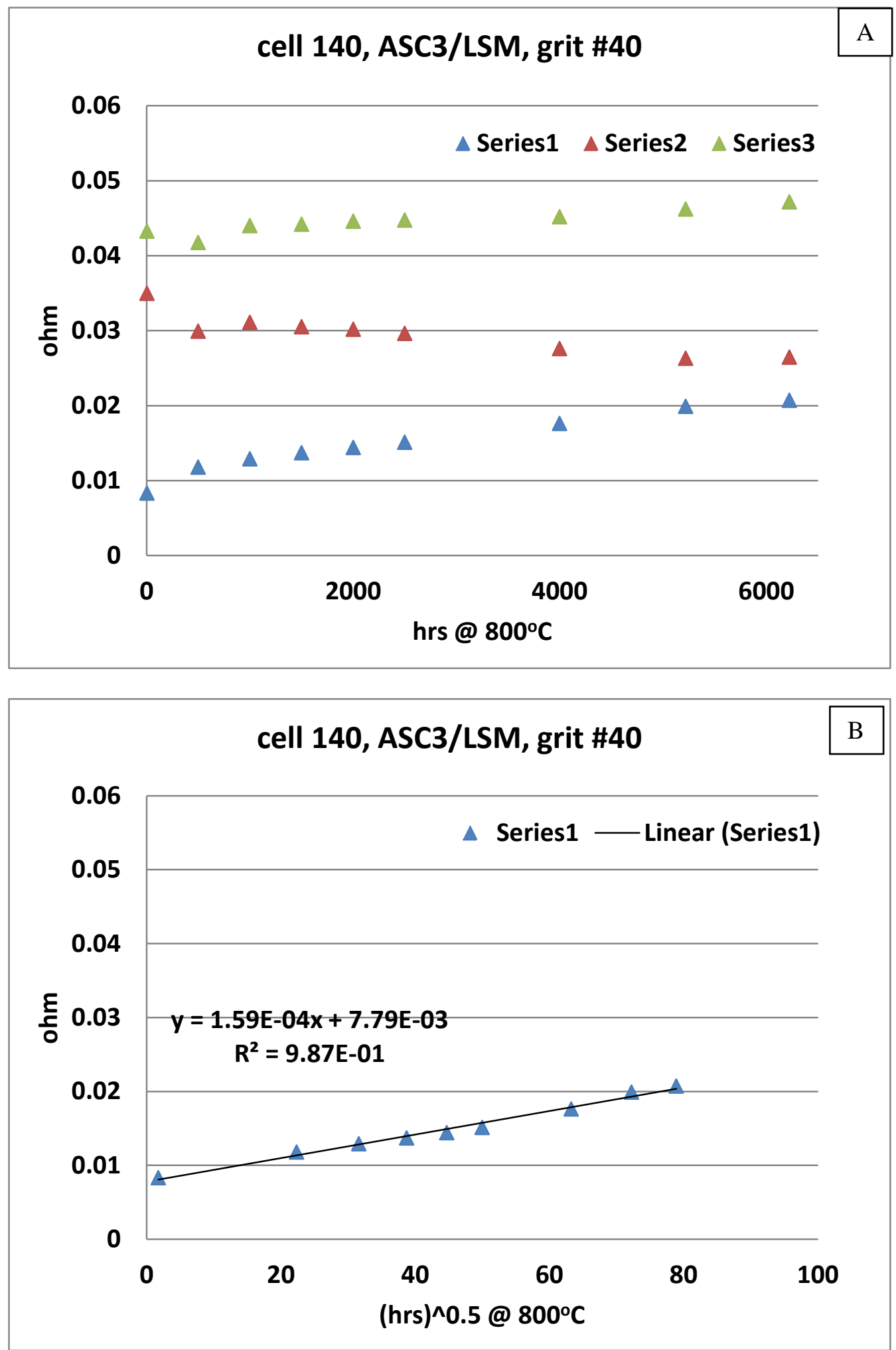

Figure 7. Impedance change with time of long-term $(6223 \mathrm{~h})$ tested cell with surface-blasted (grit \#40), spinel-coated AISI441 interconnect at $800^{\circ} \mathrm{C}$ : (A) impedance versus time plot, and (B) ohmic part versus (time) ${ }^{0.5}$ plot. 

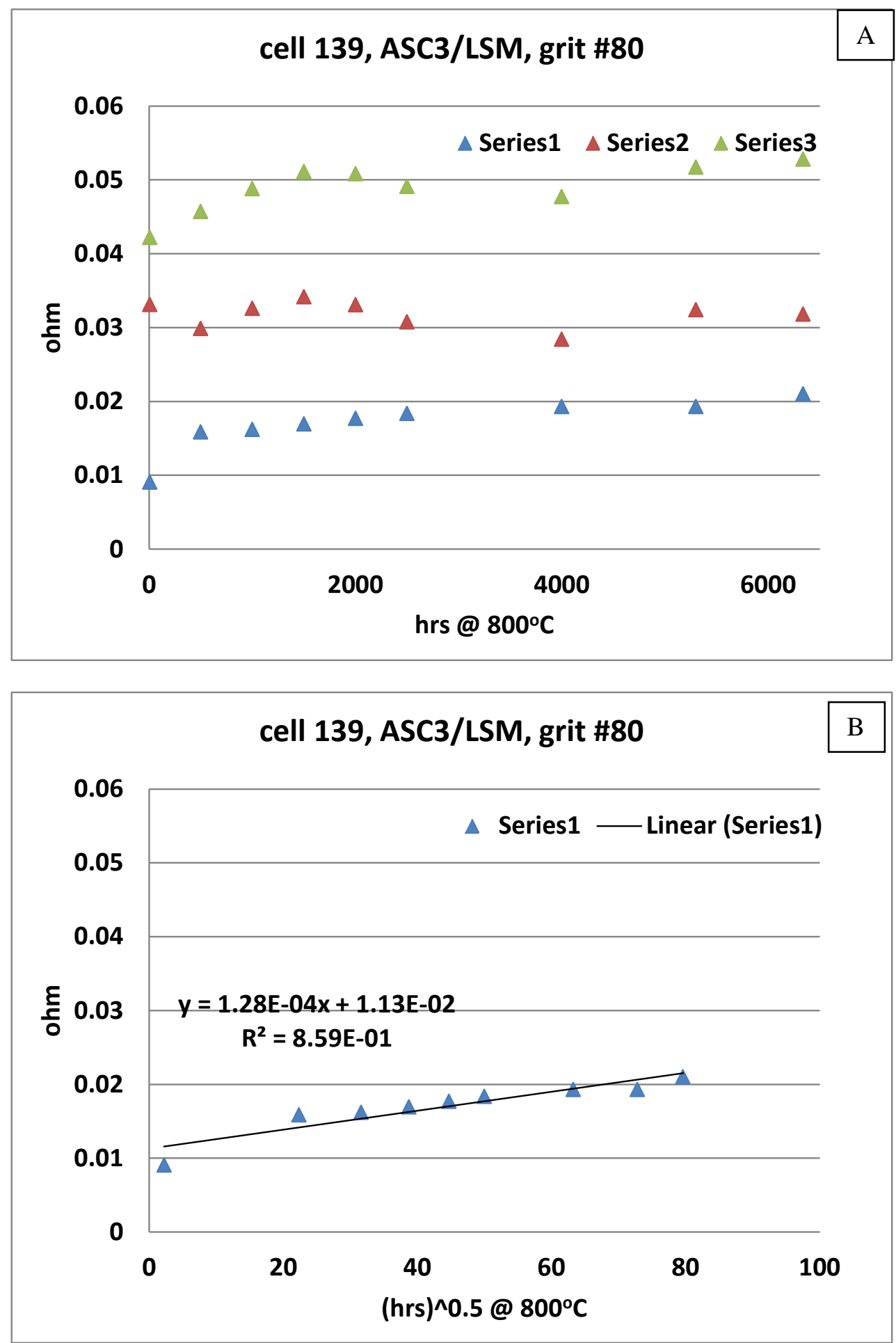

Figure 8. Impedance change with time of long-term (6340h) tested cell with surface-blasted (grit \#80), spinel-coated AISI441 interconnect at $800^{\circ} \mathrm{C}$ : (A) impedance versus time plot, and (B) ohmic part versus (time) ${ }^{0.5}$ plot. 

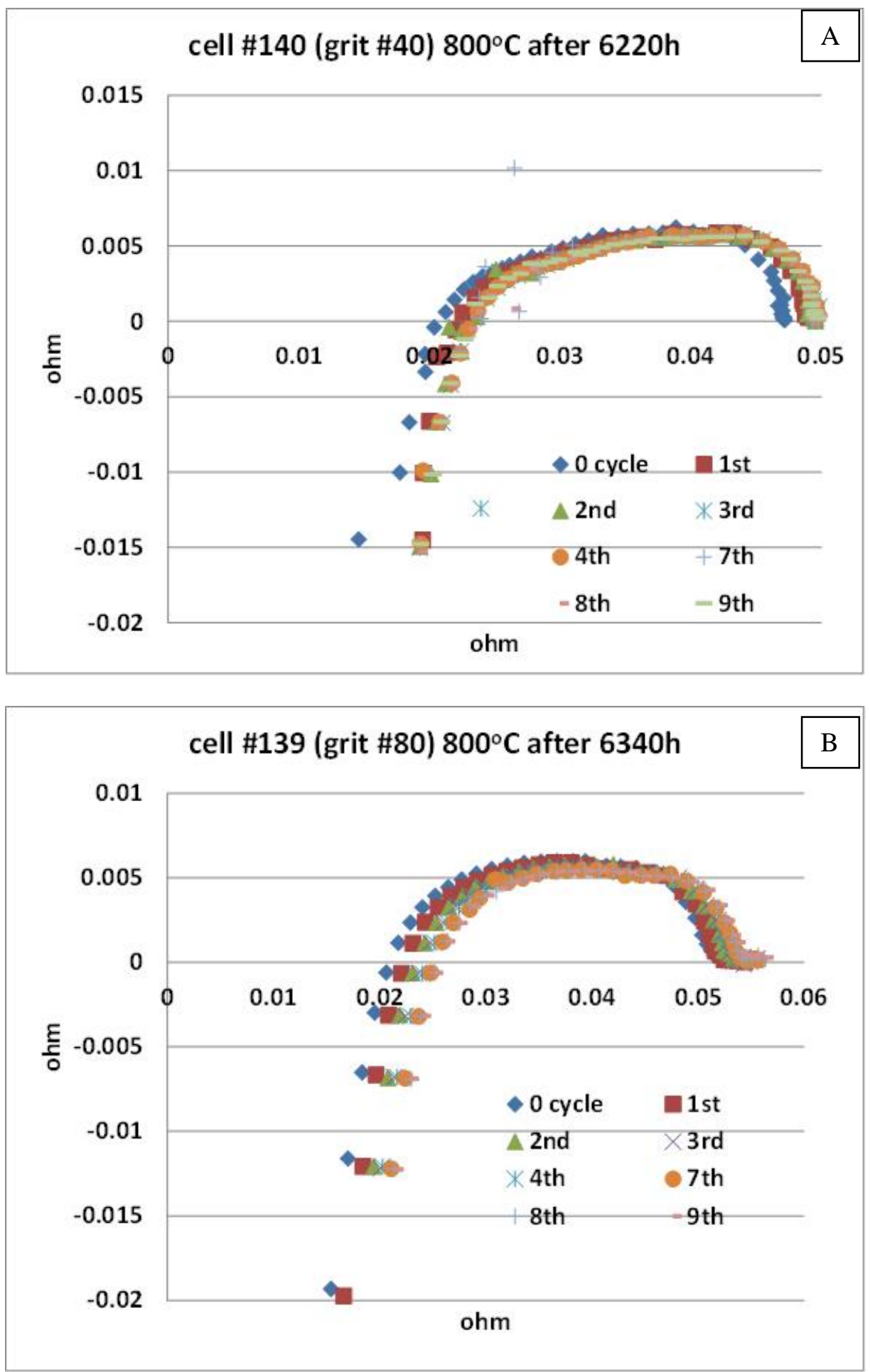

Figure 9. Effect of thermal cycling on cell impedance after the long-term stability test, (A) cell \#140 with interconnect blasted with coarse grit (\#40), and (B) cell \#139 with interconnect blasted with fine grit \#80. 

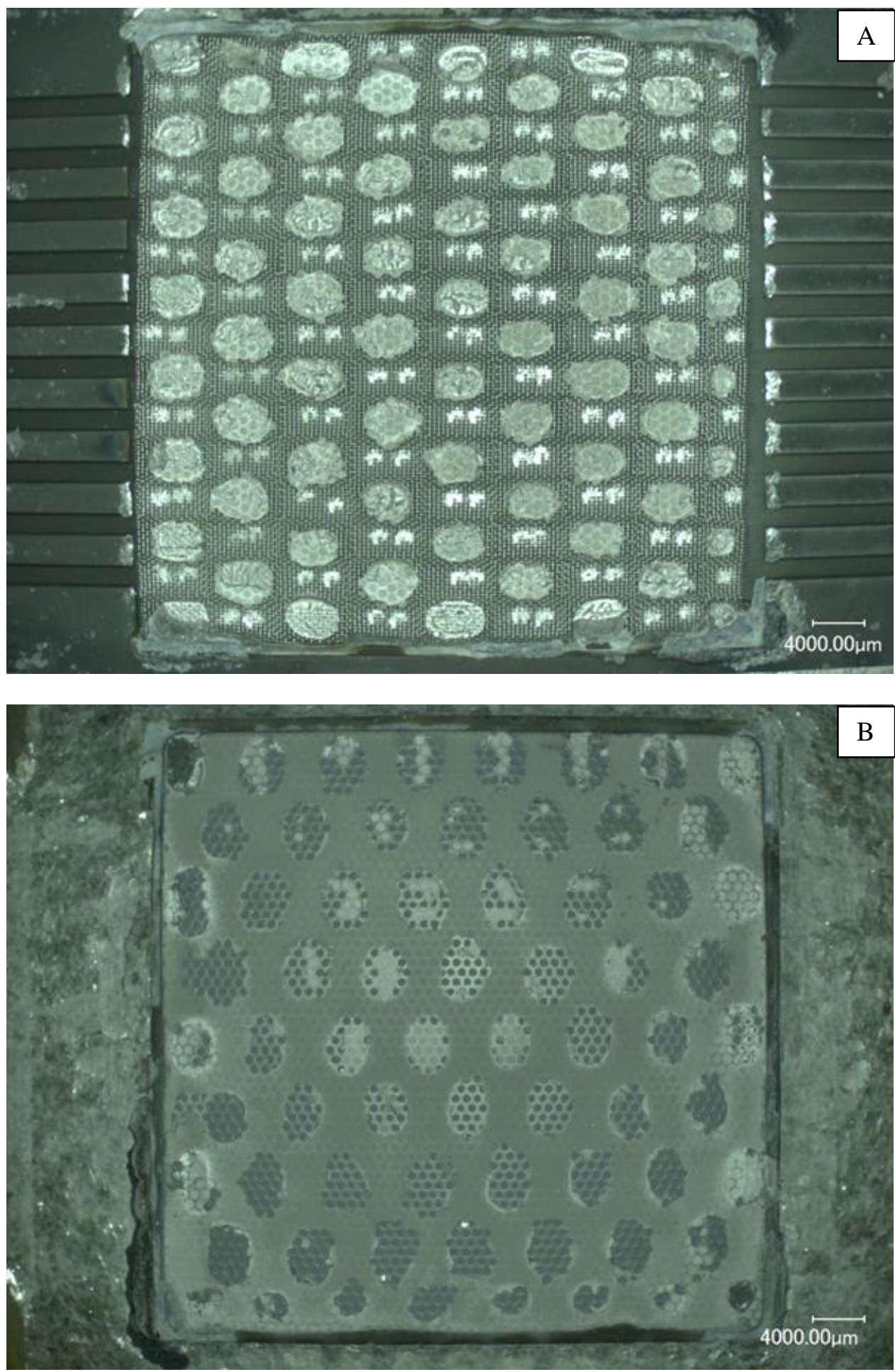

Figure 10. Post-test analysis of cell \#140 with surface-blasted (grit \#40), spinel-coated AISI441 interconnect after long-term test at $800^{\circ} \mathrm{C}$ : (A) anode side of the interconnect, and (B) anode side of cell. Both sides showed typical gray color of reduced Ni without any discoloration, consistent with hermetic sealing, as indicated from lack of cross-bubbling at room temperature. 

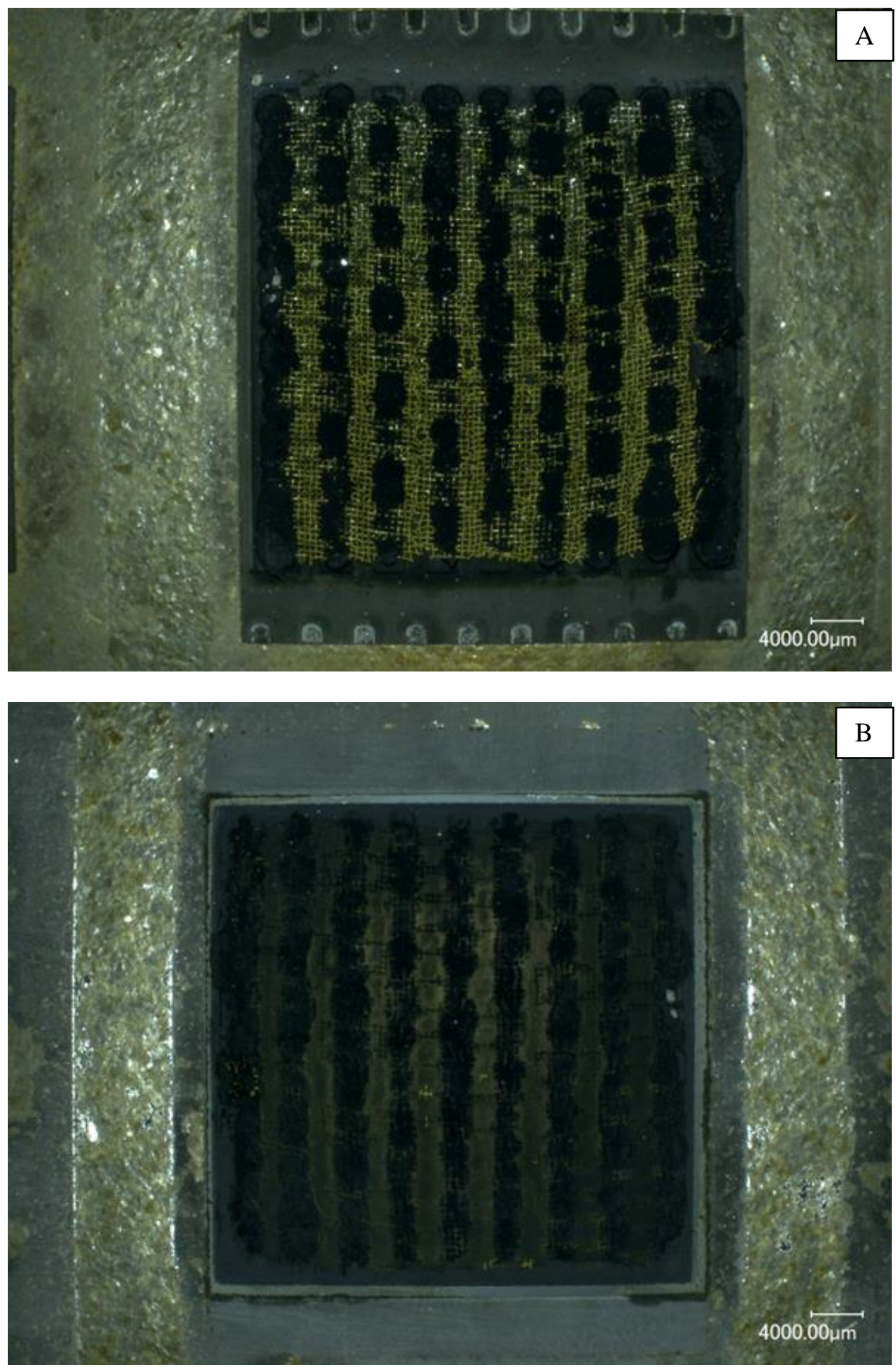

Figure 11. Post-test analysis of cell \#140 with surface-blasted (grit \#40) and spinel-coated AISI441 interconnect after long-term test at $800^{\circ} \mathrm{C}$ : (A) cathode side of the interconnect, and (B) cathode side of the cell. Both sides showed no discoloration along sealing edges, consistent with hermetic sealing, as indicated from lack of cross-bubbling at room temperature. 


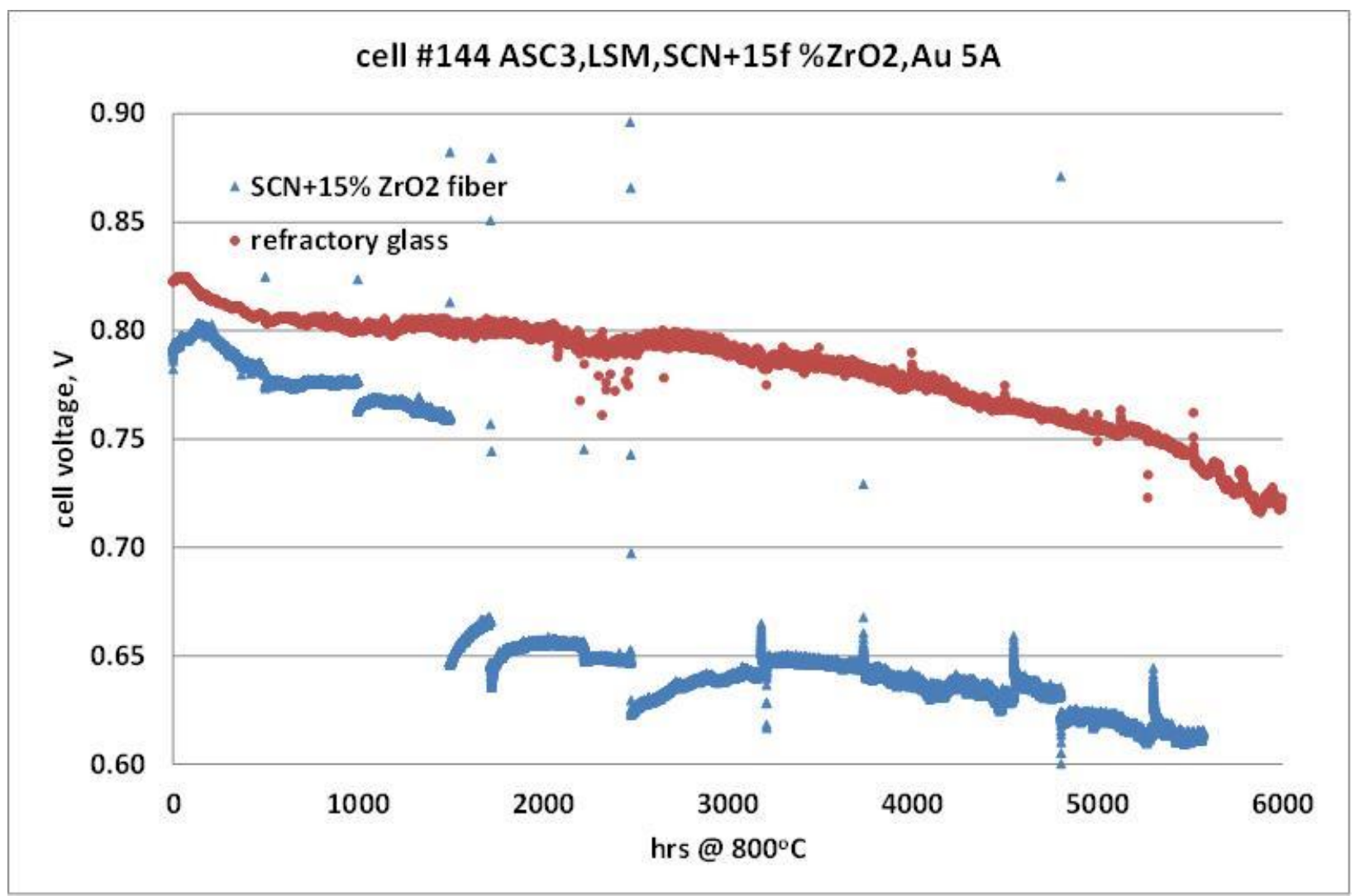

Figure 12. Long-term evaluation of engineered compliant glass ( $\mathrm{SCN}-1$ with $15 \mathrm{v} \% \mathrm{ZrO}_{2}$ fibers) in stack fixture test using LSM-based cell and LSM cathode contact at $800^{\circ} \mathrm{C}$ in constant current mode. 


\section{Glass Seal Development (Matt Chou, Eric Riel)}

Summary:

During the first quarter of FY14, a long-term stability test of an engineered compliant glass seal in the SECA CTP stack fixture continued. After reaching 6000h of operation, the test will be terminated and the stack test components will be subjected to microstructural analysis. A pore coarsening study on plain and engineered compliant sealing glass is also in progress; this test will be terminated after reaching $4000 \mathrm{~h}$. Microstructural analysis of $2000 \mathrm{~h}$ samples showed that $\mathrm{ZrO}_{2}$ short fibers were most effective in minimizing the pore coarsening process, with a more uniform distribution of pores, while plain $\mathrm{SCN}-1$ glass showed many large pores in contact with both mating surfaces. Details of the pore coarsening study are discussed below.

\section{Compliant Glass Development}

A long-term pore coarsening study is on-going and has reached over $2000 \mathrm{~h}$. Images of samples after 2000h ageing in air are presented in Figures 1, 2, and 3 for temperatures of 750, 800 , and $850^{\circ} \mathrm{C}$, respectively. Figure 1 shows the glass microstructure between two ceramic bilayers aged at $750^{\circ} \mathrm{C}$ for plain $\mathrm{SCN}-1, \mathrm{SCN}-1$ with crushed $\mathrm{ZrO}_{2}$ hollow spheres (5:1 ratio), and $\mathrm{SCN}-1$ with $\mathrm{ZrO}_{2}$ short fibers $(15 \mathrm{v} \%)$ in Figures $1 \mathrm{~A}, 1 \mathrm{~B}$, and $1 \mathrm{C}$, respectively. It appeared that the pore population density was highest for the glass with $15 \mathrm{v} \% \mathrm{ZrO}_{2}$ fibers. The glass with the crushed $\mathrm{ZrO}_{2}$ hollow spheres showed similar density to the plain SCN-1 glass. At higher temperatures, 800 and $850^{\circ} \mathrm{C}$, the presence of crushed hollow $\mathrm{ZrO}_{2}$ spheres appeared to retard the pore coalescence processes as compared to the plain $\mathrm{SCN}-1$ glass, i.e., Figure $2 \mathrm{~B}$ versus $2 \mathrm{~A}$, and Figure $3 \mathrm{~B}$ versus $3 \mathrm{~A}$, respectively. The glass with short $\mathrm{ZrO}_{2}$ fibers still had higher pore population densities, with less degree of pore coarsening, as compared to the crushed hollow spheres. These micrographs were also shared with PNNL's modeling group to help them test their model for life prediction. In comparing fillers (short fibers versus crushed hollow spheres), the current results suggest that short fibers are more effective in retarding pore coarsening than crushed hollow spheres. This is likely due to the more uniform size distribution of the short fibers compared to the crushed hollow spheres, which led to higher populations for the short fibers. 

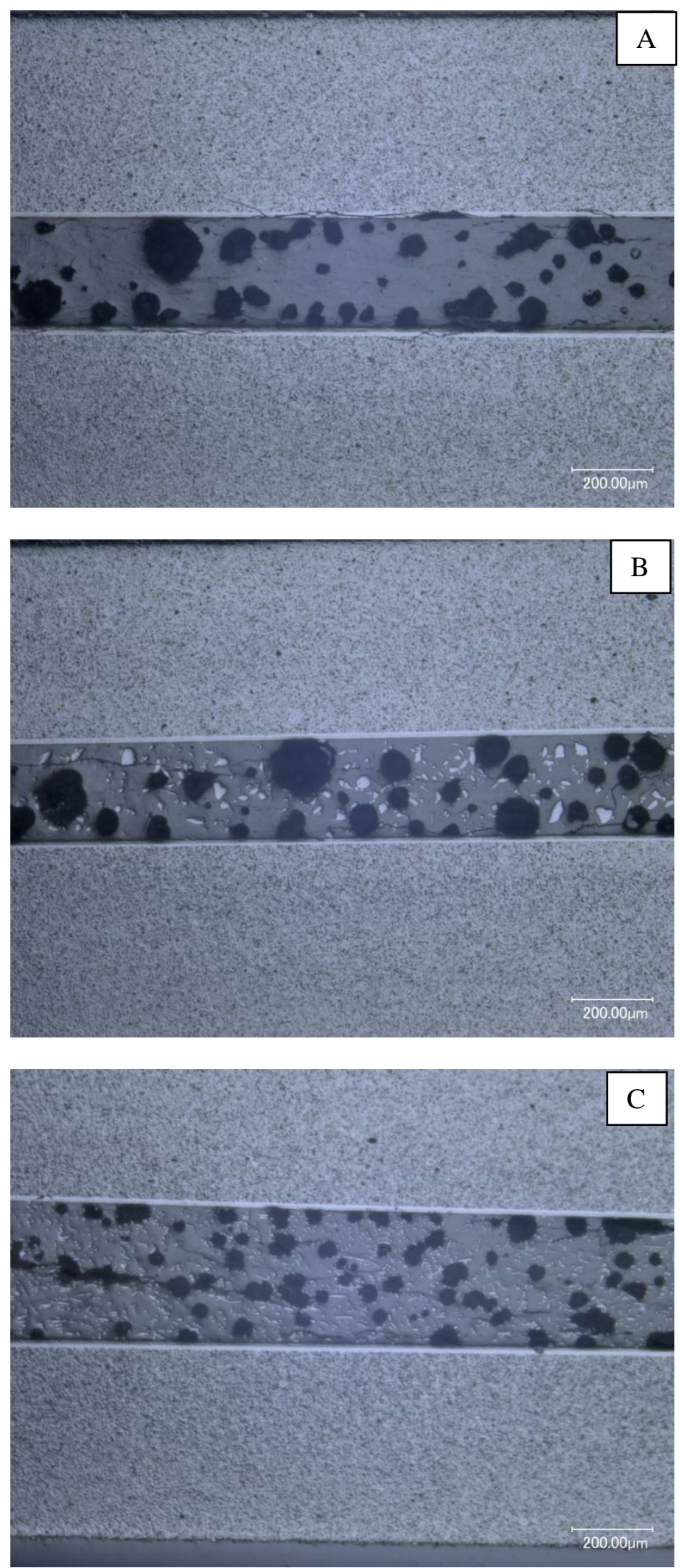

Figure 1. Glass microstructure after aging at $750^{\circ} \mathrm{C} / 2000 \mathrm{~h},(\mathrm{~A})$ plain $\mathrm{SCN}-1$, (B) with crushed $\mathrm{ZrO}_{2}$ hollow spheres, (C) with $15 \% \mathrm{ZrO}_{2}$ short fibers. 

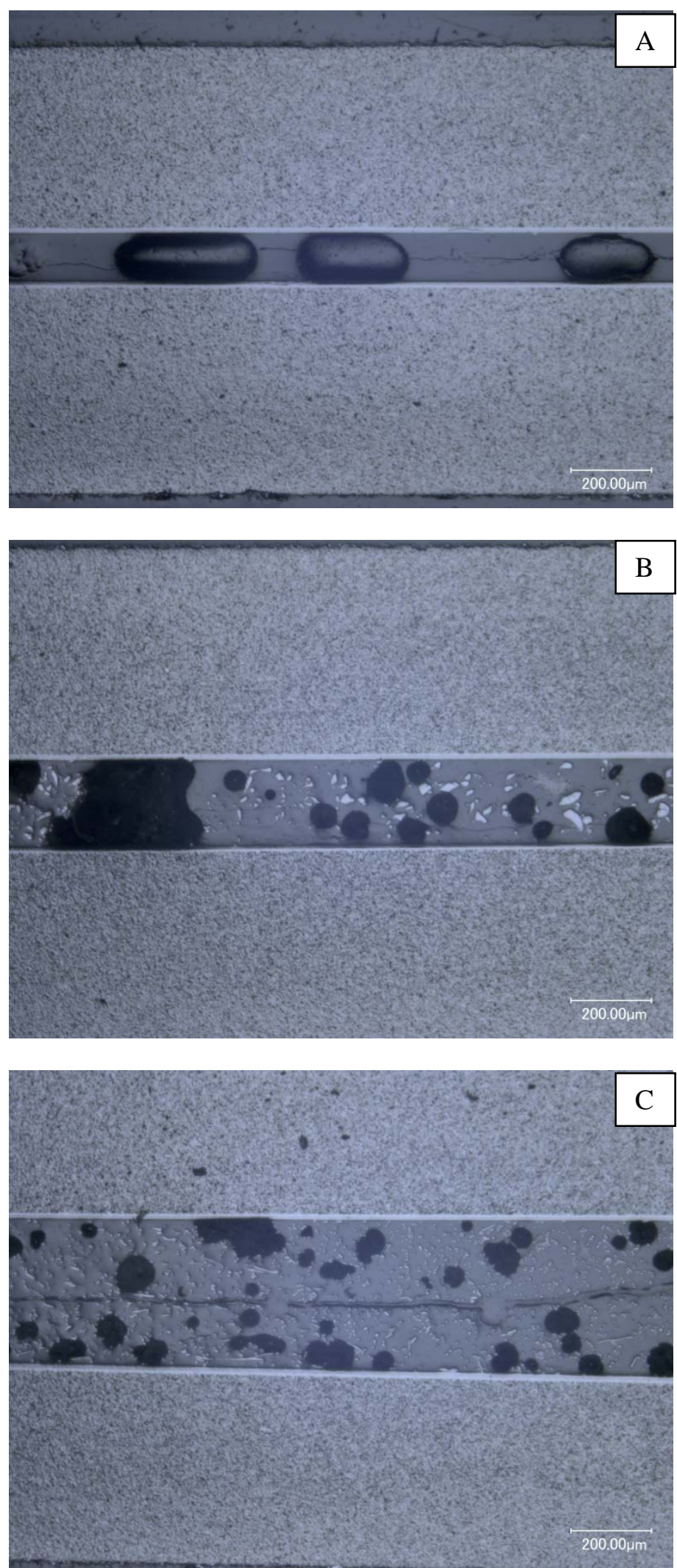

Figure 2. Glass microstructure after aging at $800^{\circ} \mathrm{C} / 2000 \mathrm{~h},(\mathrm{~A})$ plain $\mathrm{SCN}-1$, (B) with crushed $\mathrm{ZrO}_{2}$ hollow spheres, (C) with $15 \% \mathrm{ZrO}_{2}$ short fibers. 

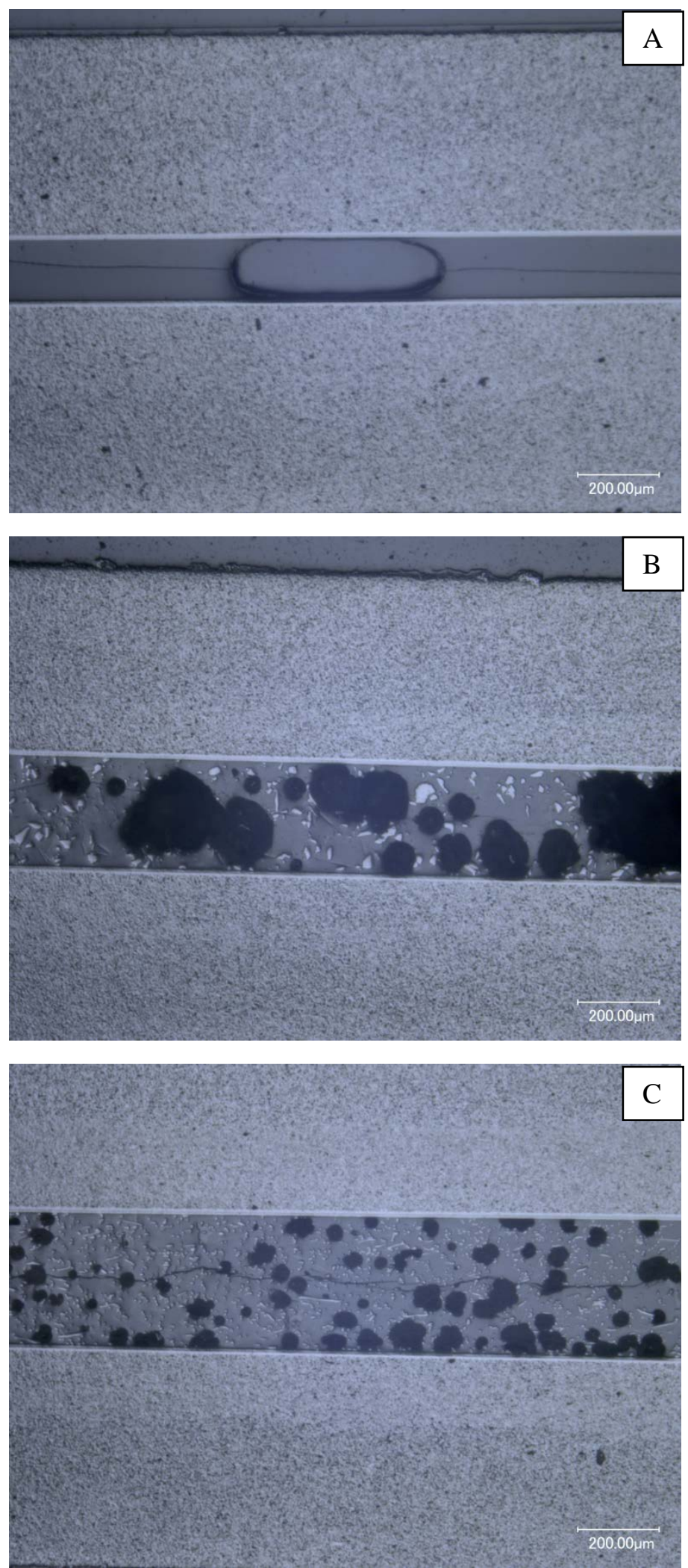

Figure 3. Glass microstructure after aging at $850^{\circ} \mathrm{C} / 200 \mathrm{~h},(\mathrm{~A})$ plain $\mathrm{SCN}-1$, (B) with crushed $\mathrm{ZrO}_{2}$ hollow spheres, (C) with $15 \% \mathrm{ZrO}_{2}$ short fibers. 


\section{Anode Development (Olga Marina, Chris Coyle)}

High fuel utilization conditions are likely to exist during the SOFC operation, in particular at high temperatures, towards the end of the cell. From the literature and our previous tests it is known that nickel catalysts and nickel SOFC anodes are susceptible to coarsening when exposed to high steam concentration at high temperatures. Because the exchange current density is directly related to the nickel particle size, coarsening could lead to a reduction in anode activity.

As reported previously, SOFC performance was lowered during $>1000$ hours operation at $900^{\circ} \mathrm{C}$ with a high steam content in the fuel gas corresponding to $80-90 \%$ reformate utilization; it is possible that the performance loss was due to Ni particle coarsening within the active anode. Exposure of Ni/YSZ coupons for up to 5000 hours in a fuel atmosphere corresponding to 80$90 \%$ fuel utilization resulted in microstructures that were analyzed by SEM with subsequent image analyses. The observed enlarged nickel particle size and decreased number of triple point contacts between Ni-YSZ-gas indeed indicated Ni coarsening. A Ni particle growth model developed for $\mathrm{Ni}$ catalysts was adopted to estimate coarsening rates. Experimental validation of this model as well as determination of SOFC degradation rates related to coarsening are currently under study.

The experimental data presented in this report are from the cells that are currently being eveluated. Most of the tests are in their initial to intermediate stage of the testing period. The ultimate goal of this task is to obtain the cell perfromnce data over a very long period of time, $\sim 5,000$ hours, to separate any losses associated with the $\mathrm{Ni}$ anode degradation in the presence of high humidity, and to correlate them to the possible active anode microstructural changes.

Standard Ni/YSZ anode supported button cells were fabricated using 5\% A-site deficient LSM-20/YSZ cathodes with a gold current collector. A NiO grid was printed on the anode and fired at $1200^{\circ} \mathrm{C}$ for 2 hours. The LSM/YSZ cathode was then printed on the cell and sintered at $1100^{\circ} \mathrm{C}$ for 2 hours. A gold ink grid pattern was printed on the cathode surface and a gold mesh with platinum lead wires was pressed into it. This structure was then sintered at $875 \mathrm{C}$ for 1 hour. These cells were then sealed onto alumina test fixtures using glass rings. 8 test fixtures were assembled in each furnace and then first heated to $850^{\circ} \mathrm{C}$ to complete the sealing process, then lowered to $800^{\circ} \mathrm{C}$ for testing. Electrolyte supported cells were purchased from Fuel Cell Materials. A gold current collector with platinum lead wires was pressed into a printed gold grid on the cathode and sintered at $875 \mathrm{C}$ for 1 hour. These cells were then sealed onto alumina test fixtures using glass rings. 8 test fixtures were assembled and heated in a furnace directly to $900^{\circ} \mathrm{C}$ for testing.

The cells were reduced using a mixture of $95 \%$ hydrogen and $5 \% \mathrm{CO}_{2}$ to the anode and $93 \%+$ oxygen (produced by an oxygen generator) to the cathode. The cells were activated at $0.8 \mathrm{~V}$ to produce a baseline performance. The gas mixture was then changed to $55 \% \mathrm{H}_{2}-45 \%$ $\mathrm{CO}_{2}$ to produce an equilibrated simulated reformate $\mathrm{H}_{2} / \mathrm{CO} / \mathrm{H}_{2} \mathrm{O} / \mathrm{CO}_{2}=30 / 25 / 25 / 20$. The humidity content was adjusted by adding oxygen to simulate high fuel utilizations with humidity content up to $52 \%: \mathrm{H}_{2} / \mathrm{CO} / \mathrm{H}_{2} \mathrm{O} / \mathrm{CO}_{2}=3 / 2 / 52 / 43$. DC data was collected using an Arbin Instruments battery testing system, recording a voltage reading every 5 minutes over the duration of the test. AC electrochemical impedance was collected using a Gamry Reference 3000 instrument at periodic intervals.

Typical test results obtained at $800^{\circ} \mathrm{C}$, (cell voltage at a constant current, calculated area specific resistance (ASR), and impedance spectra), are given in Figures 1-3 for three cells. One 
cell was tested at a humidity level corresponding to $80 \%$ fuel utilization, another was tested at humidity level corresponding to $90 \%$ fuel utilization, and the third was tested on synthetic reformate without increased humidity to serve as a control. At this point, the test has been in progress for over 2500 hours. As seen in Figures 1-2, there were no visible changes in the performance for about 1500 hours. Then, at around 1580 hours, an unknown event occurred that caused all three cells (and several others located in the same furnace) to exhibit a change in performance. The slope of the time dependence for at least two of the cells - control and $80 \%$ fuel utilization - was affected. The cell tested at $90 \%$ fuel utilization was less affected by the event. It is not clear whether operation of the cell at a lower current density compared to the other two minimized the impact. The impedance spectra of these cells are given in Figures $3 \mathrm{a}$ and $3 \mathrm{~b}$. The polarization resistance of the control cell, Figure $3 \mathrm{~b}$, did not change, while the ohmic component shifted toward higher values at around 1560 hours into testing. The time next to each spectrum corresponds to either real test time (control cell) or to the time of exposure to high humidity (the other two cells).

Similar results are being collected from another 7 anode-supported cells at $800^{\circ} \mathrm{C}$. Three are being tested at a humidity level corresponding to $80 \%$ fuel utilization, two at $85 \%$ fuel utilization, and two control cells are also present. All of these cells show slight degradation, including controls. Again, the degradation occurs mostly in the ohmic part and could be due to coarsening or sintering of either of the current collectors (Ni paste on the anode or Au paste on the cathode). The slopes for the control cells will serve as a control and this contribution could be subtracted from the other cell degradation data to conclude whether there is any meaningfull difference. Unfortunately, the high fuel utilization data are quite noisy.

Figure 6 illustrates typical impedance spectra of the anode-supported cells obtained at humidity levels corresponding to $85 \%$ fuel utilization and $5 \%$ fuel utilization (control). It is seen that the ohmic resistance is changing the most. Figures 7-9 show the performance of the electrolyte-supported cells with the Ni/YSZ anodes at $900^{\circ} \mathrm{C}$. Although it is desirable to compare the performance of the anode-supported cells to the microstructures of the Ni/YSZ coupons at $900^{\circ} \mathrm{C}$, thus far we have been unsuccessful in conducting long-term experiments with anodesupported cells at this temperature beyond 1000 hours, as glass seal aging and creeping allowed the Ni/YSZ support to be exposed to air around the cell edges followed by Ni oxidation starting slowly from the edges and growing inward to the electrochemically active zone against the cathode. These factors dominated the cell performance degradation at $900^{\circ} \mathrm{C}$. Therefore, the electrolyte-supported cells with a Ni/YSZ anode and LSM cathode (purchased from Fuel Cell Materials, Inc) are being tested at this temperature.

Over the initial 900 hours of testing, cell performance remained relatively flat with no significant deviation that would indicate degradation. Yet, some differences between the control cell and that tested at higher humidity levels could be seen from the impedance data (Figure 9). It is seen that the cell tested at high utilization exhibits a small increase in the ohmic resistance, while the electrodic component shrinks. The tests are in progress; longer-term results will be reported in the quarter. 


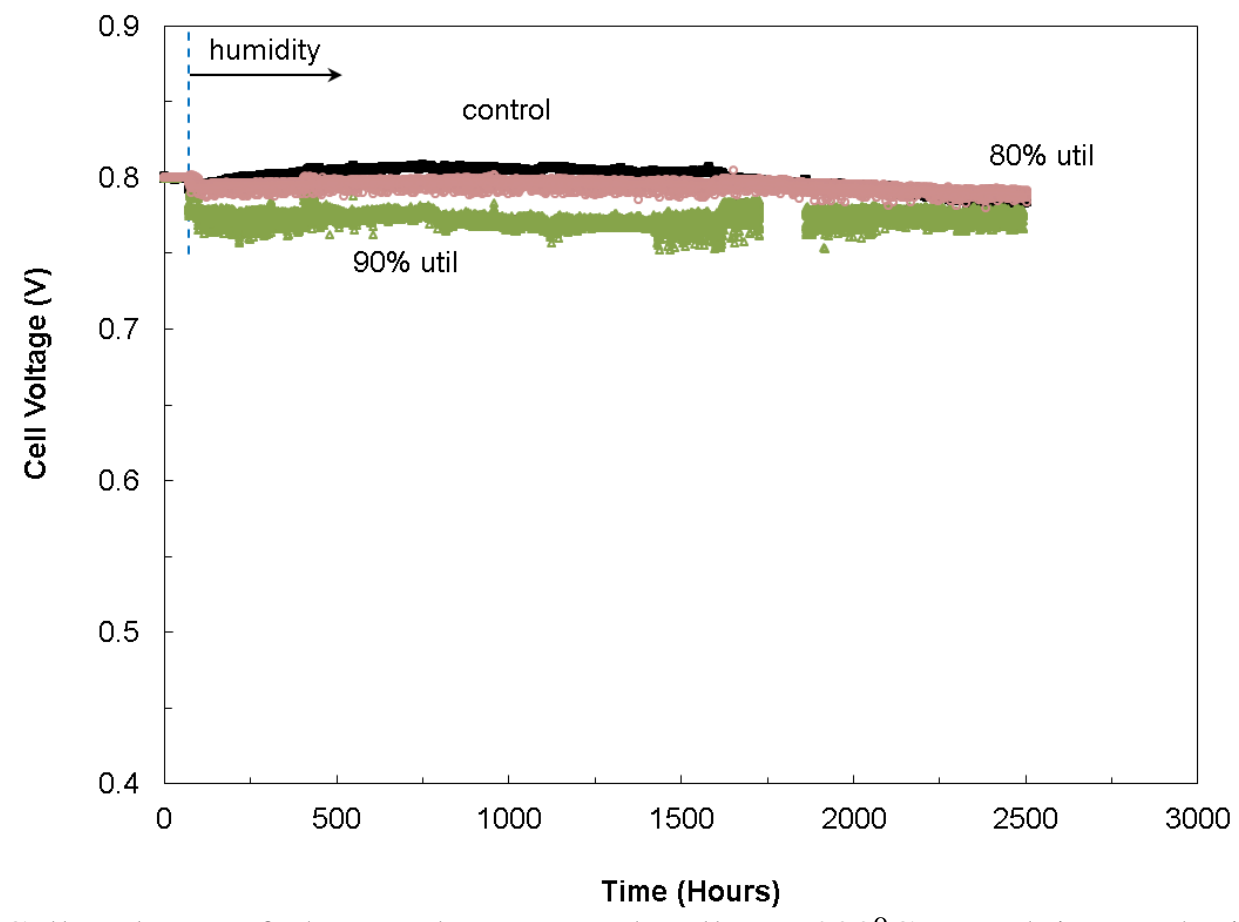

Figure 1. Cell voltage of the anode-supported cells at $800^{\circ} \mathrm{C}$ tested in synthetic reformate (control) and reformate with increased humidity corresponding to 80 and $90 \%$ fuel utilization at a fixed current density of $0.7,0.28$, and $0.13 \mathrm{~A} / \mathrm{cm}^{2}$, respectively.

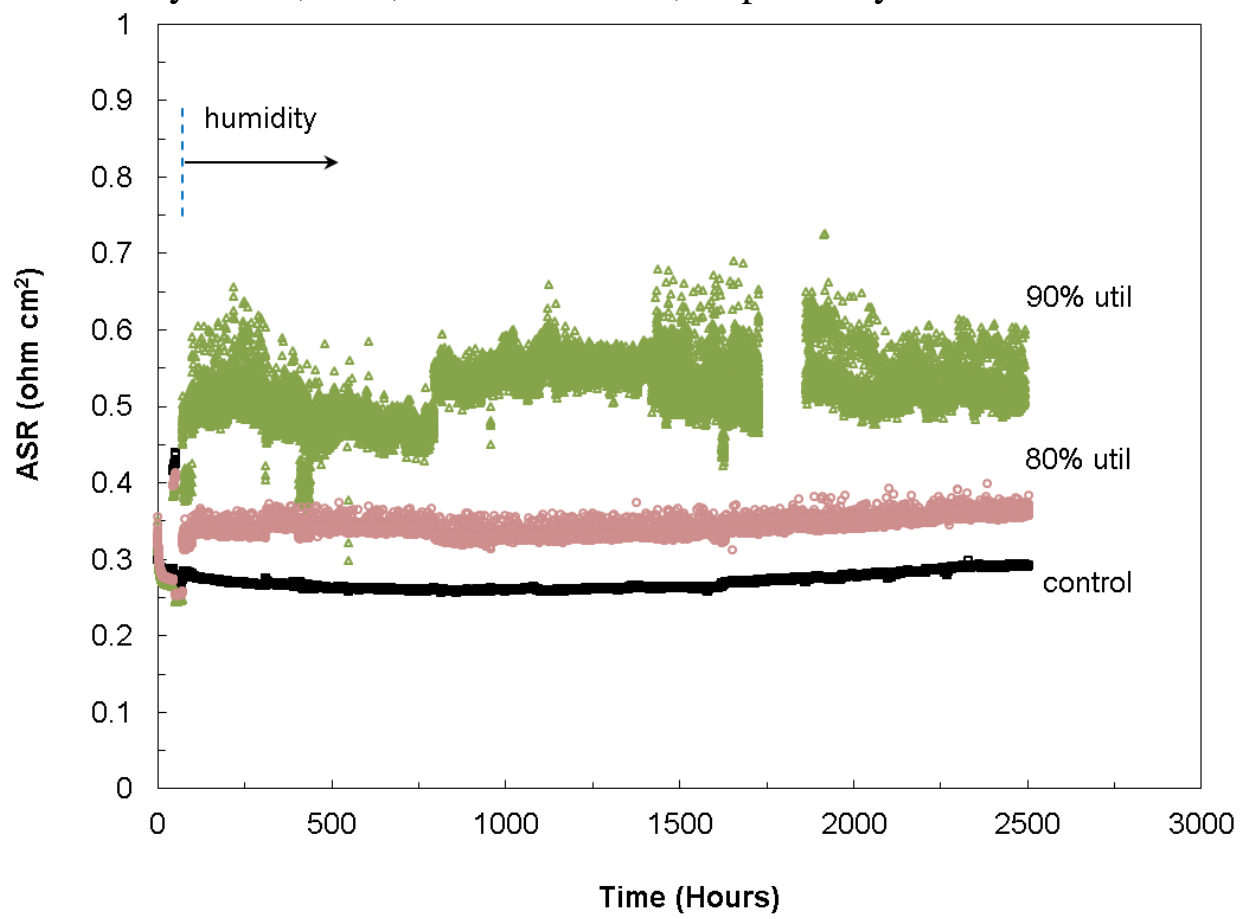

Figure 2. Area specific resistance of the YSZ electrolyte-supported cells at $800^{\circ} \mathrm{C}$. 


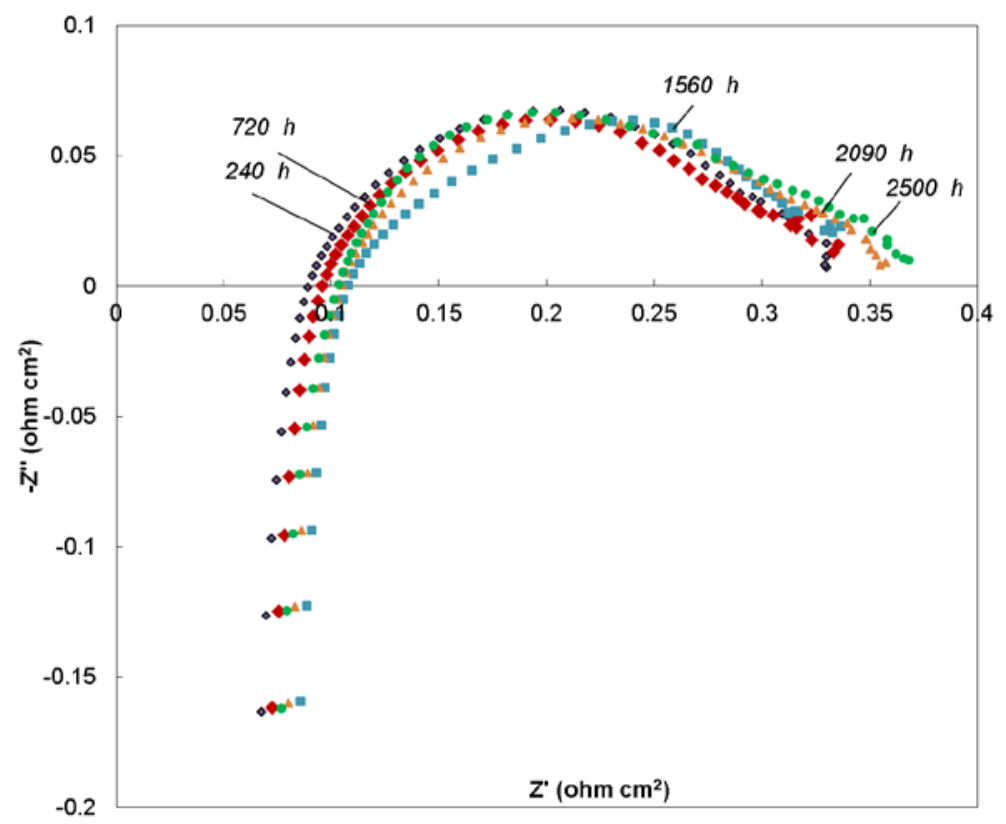

(a)

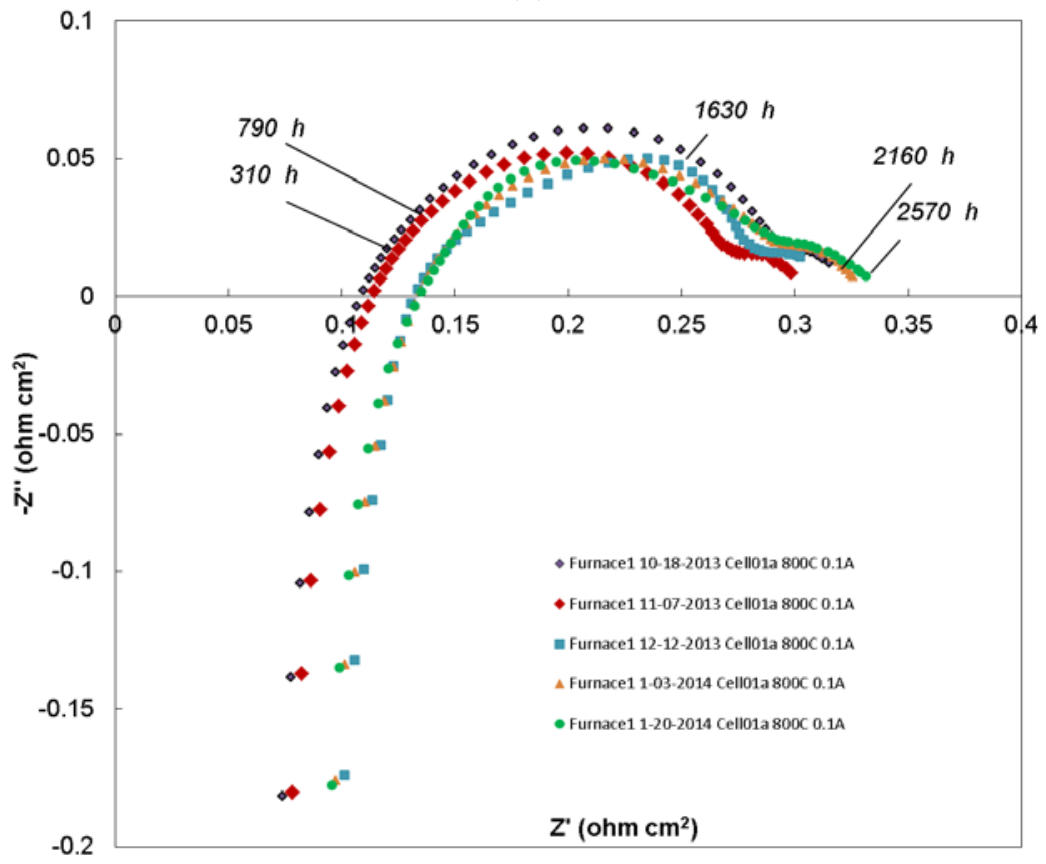

(b)

Figure 3. Impedance spectra of the anode-supported cells obtained at humidity level corresponding to $80 \%$ fuel utilization (a) and 5\% fuel utilization (control) (b). Bias current was $50 \mathrm{~mA} / \mathrm{cm}^{2} . \mathrm{T}=800^{\circ} \mathrm{C}$. There is a shift in ohmic resistance in both cells at around 1560 hours into testing. 


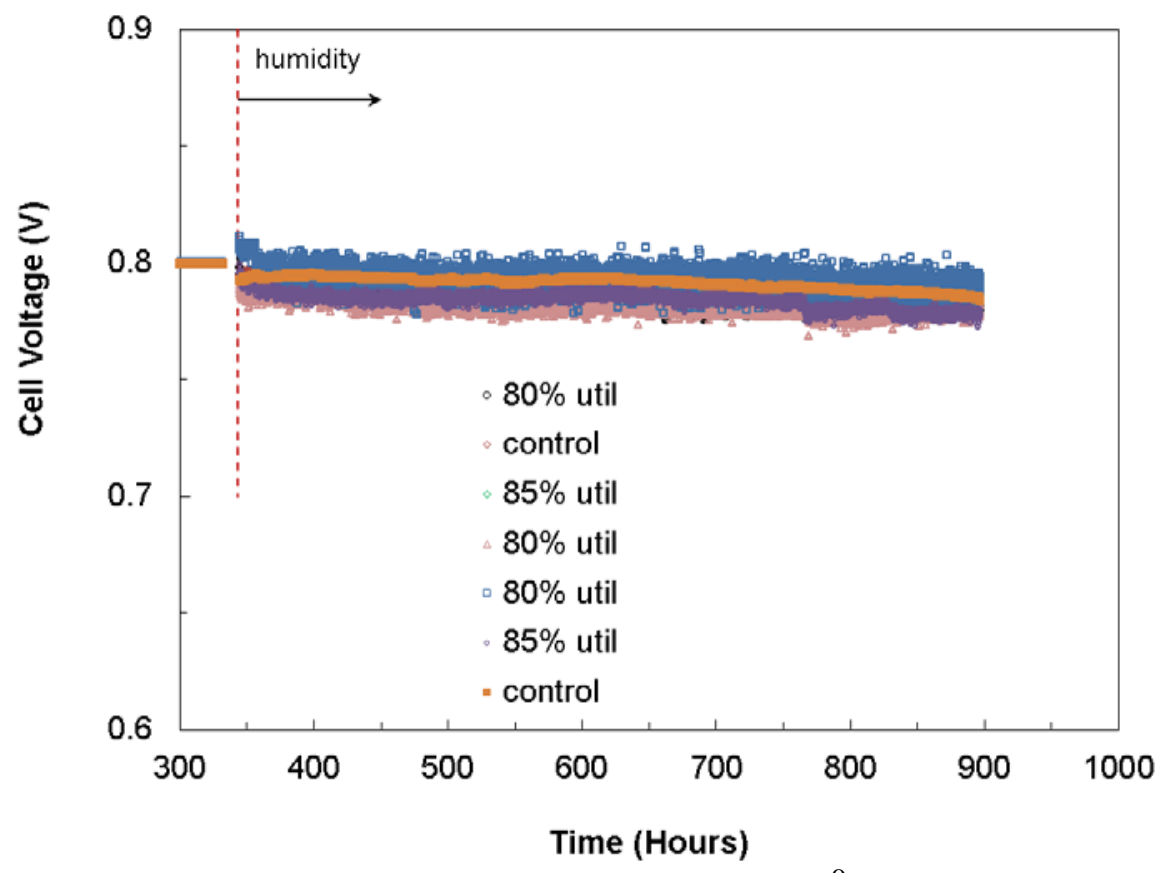

Figure 4. Cell voltage of the anode-supported cells at $800^{\circ} \mathrm{C}$ tested in synthetic reformate (control) and reformate with increased humidity corresponding to 80 and $85 \%$ fuel utilization at a fixed current density of 0.15 and $0.2 \mathrm{~A} / \mathrm{cm}^{2}$ (controls), respectively.

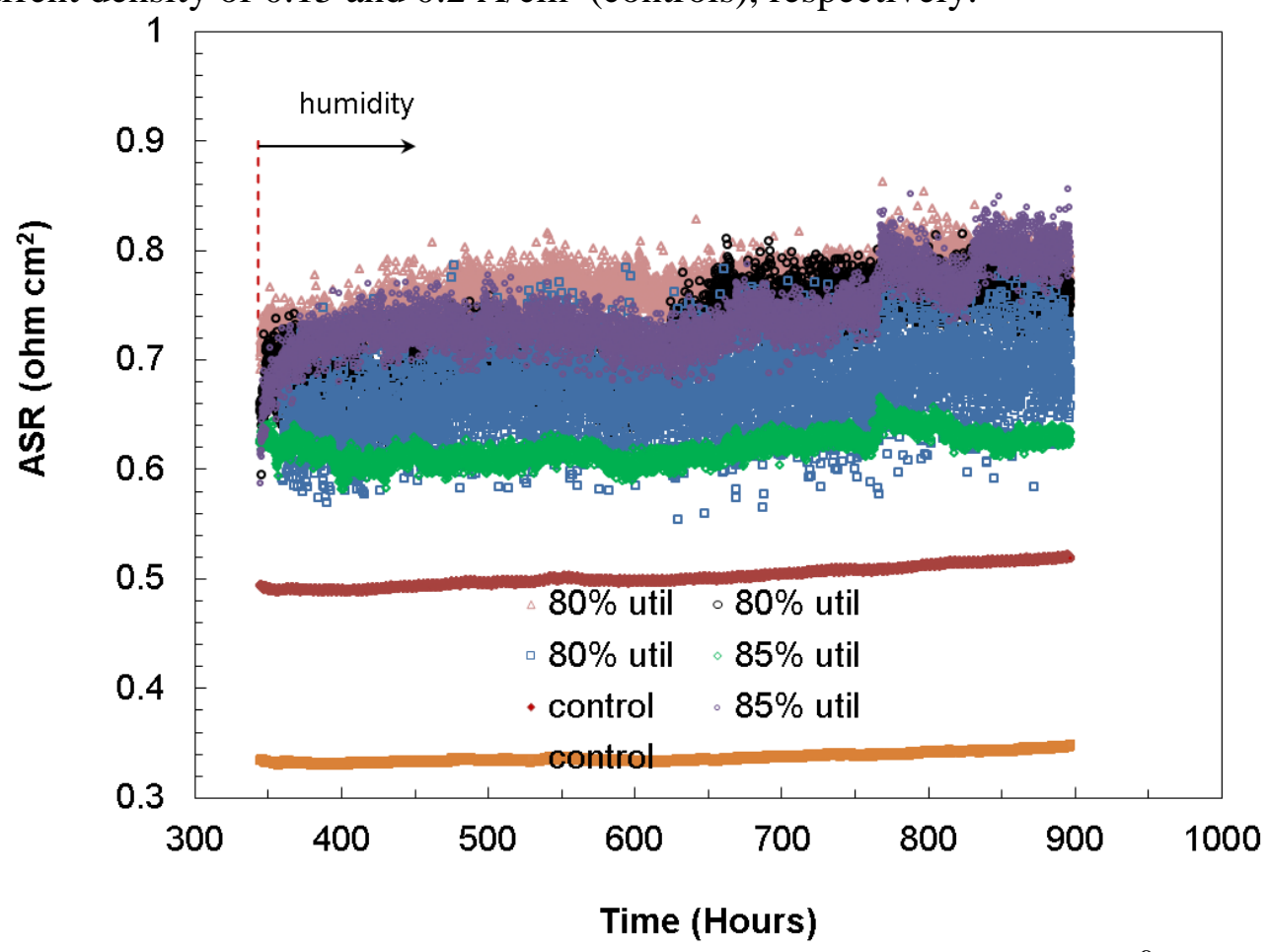

Figure 5. Area specific resistance of the YSZ electrolyte-supported cells at $800^{\circ} \mathrm{C}$. 


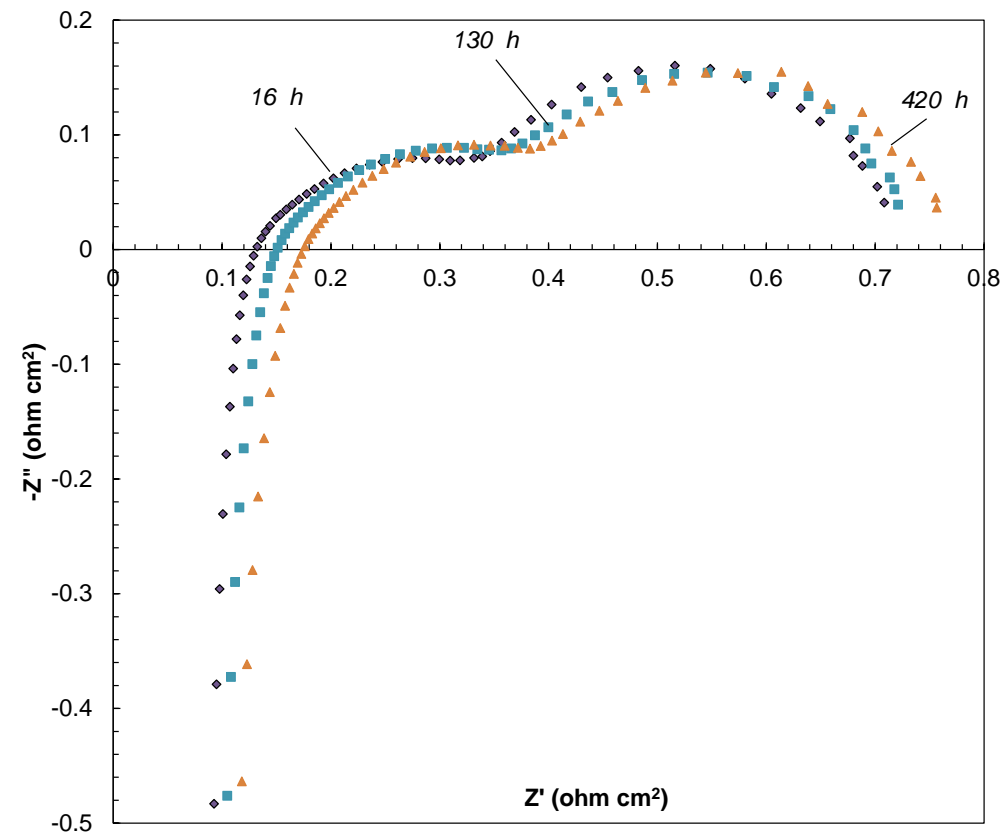

(a)

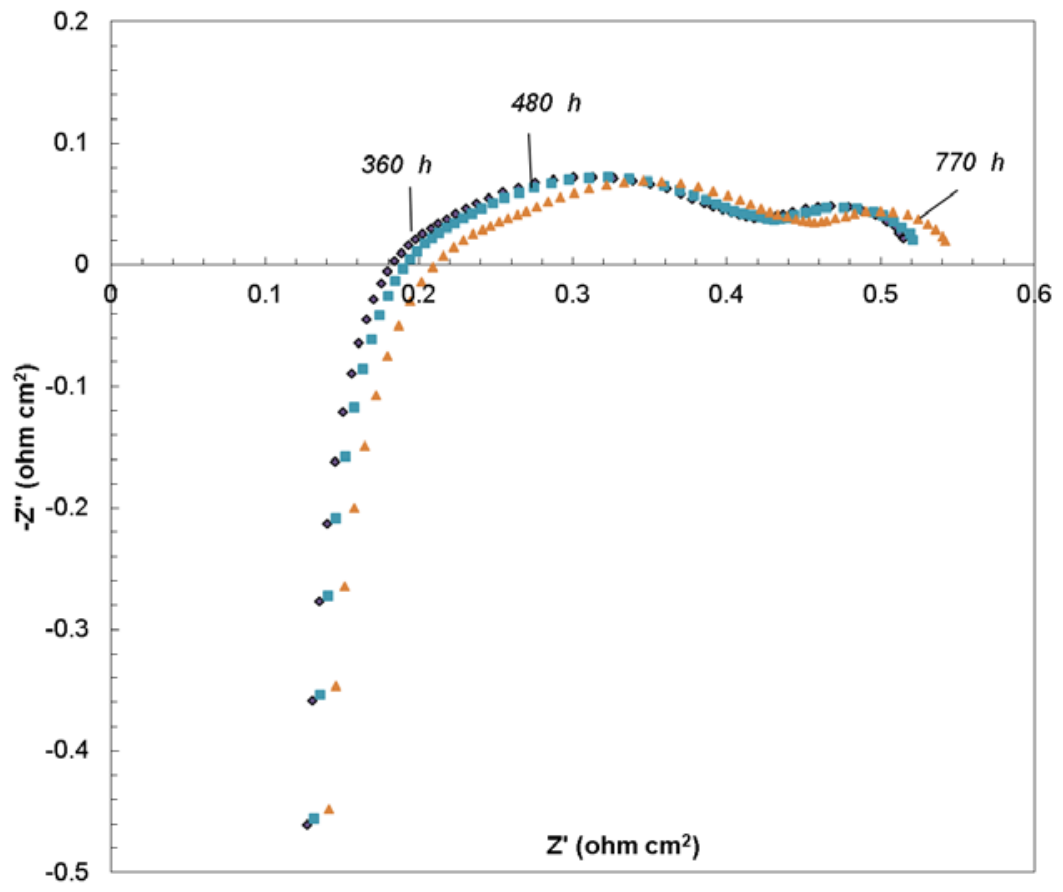

(b)

Figure 6. Impedance spectra of the anode-supported cells obtained at humidity level corresponding to $80 \%$ fuel utilization (a) and 5\% fuel utilization (control) (b). Bias current was $50 \mathrm{~mA} / \mathrm{cm}^{2} . \mathrm{T}=800^{\circ} \mathrm{C}$. The ohmic resistance changed the most. 


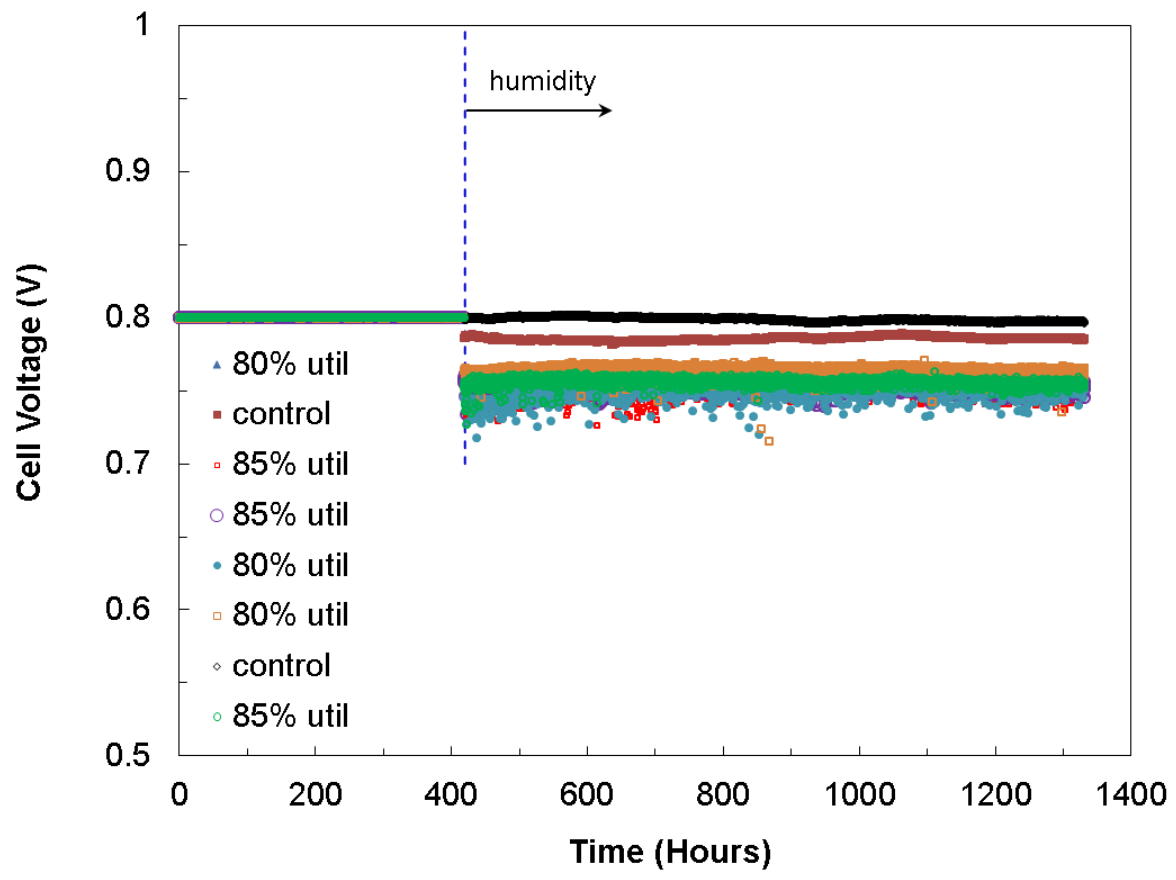

Figure 7. Cell voltages of the electrolyte-supported cells at humidity levels corresponding to 80 and $85 \%$ fuel utilizations. For the first 400 hours, the test was performed at a fixed voltage, 0.8 $\mathrm{V}$, in the synthetic reformate. From 400 hours on, the humidity to some of the cells was increased. In the beginning of the test $\mathrm{T}=900^{\circ} \mathrm{C}$, current density is $0.1 \mathrm{~A} / \mathrm{cm}^{2}$ for cells with increased humidity and $0.2 \mathrm{~A} / \mathrm{cm}^{2}$ for control cells operated on reformate gas.

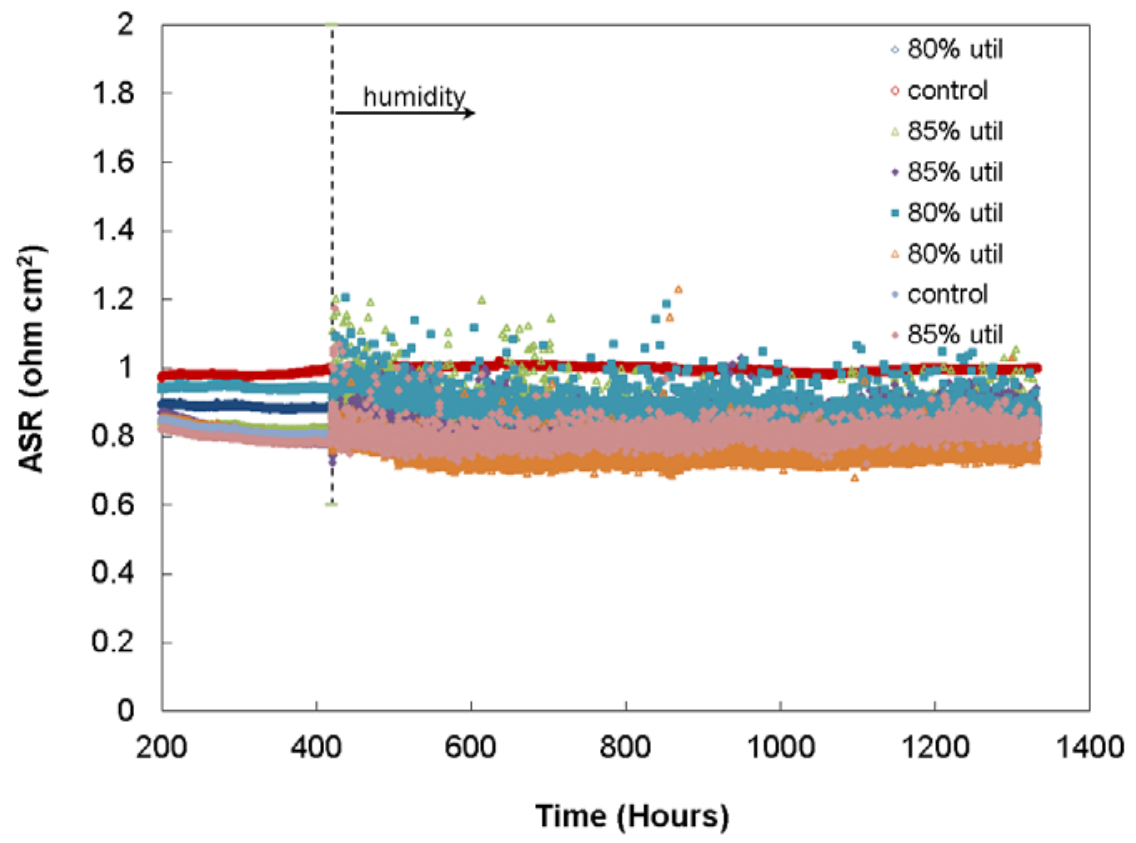

Figure 8. Area specific resistance (ASR) of electrolyte-supported cells calculated from the data given in Figure 7. $\mathrm{T}=900^{\circ} \mathrm{C}$. 


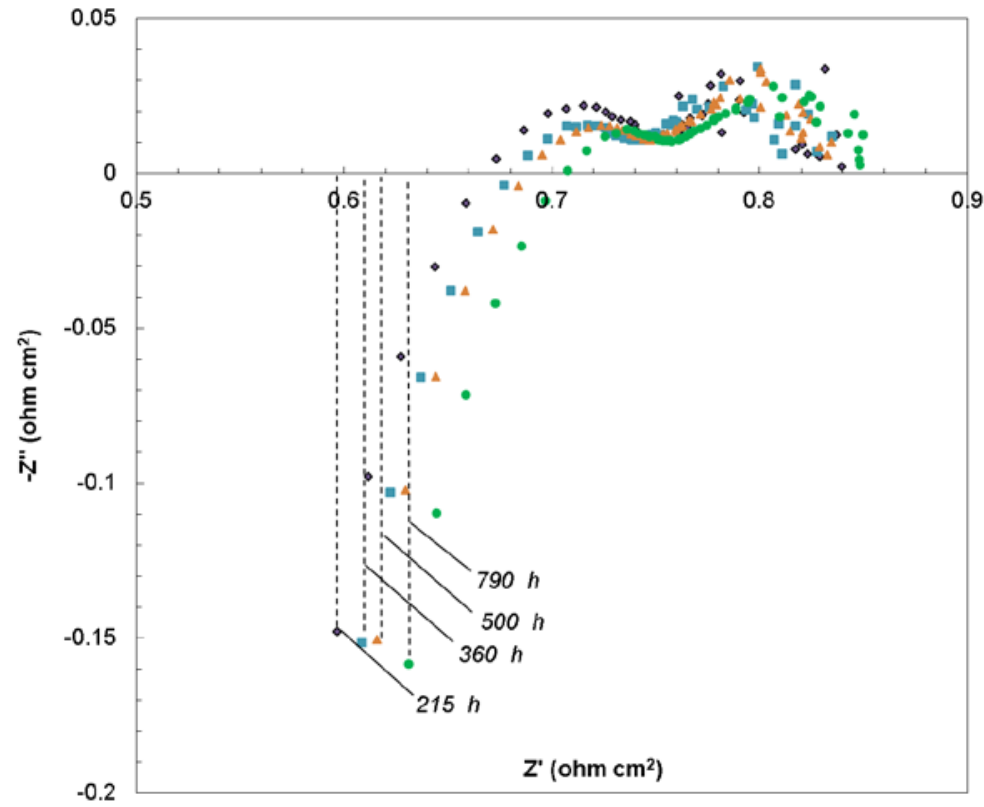

(a)

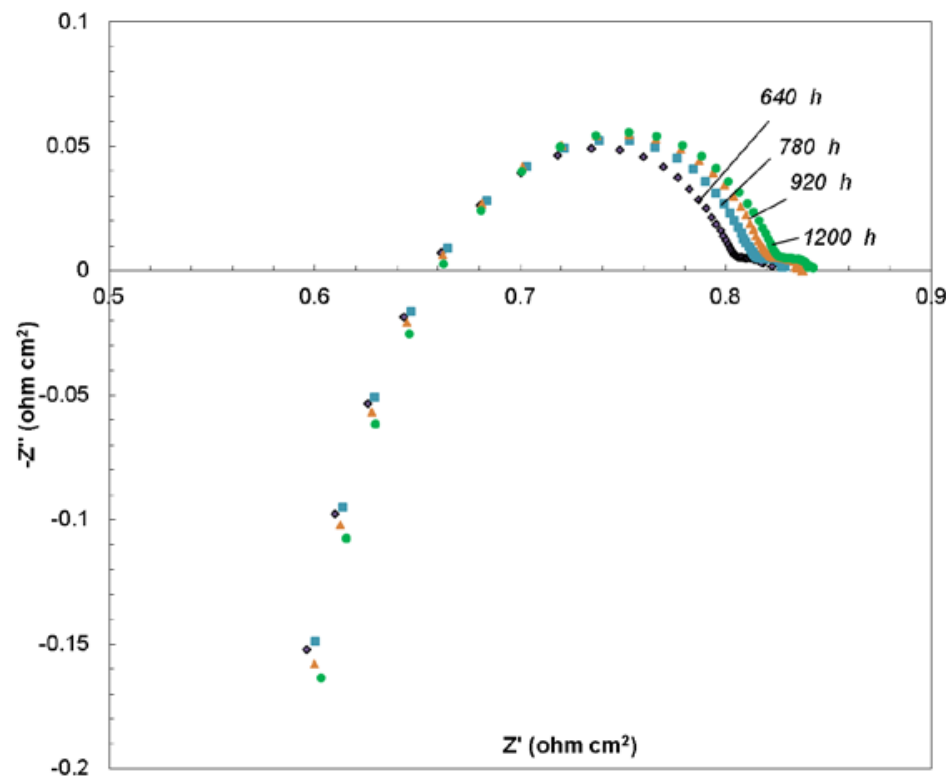

(b)

Figure 9. Impedance spectra of the electrolyte-supported cells obtained at humidity level corresponding to $85 \%$ fuel utilization (a) and 5\% fuel utilization (control) (b). Bias current was $50 \mathrm{~mA} / \mathrm{cm}^{2}$ (a) and $200 \mathrm{~mA} / \mathrm{cm}^{2}$ (b). T=900 ${ }^{\circ} \mathrm{C}$. Both plots appear to indicate a slight increase in cell resistance with time. While an increase in polarization losses was comparable in both cases, it is seen in Figure 9a that it is the ohmic resistance (the high frequency intercept with the $\mathrm{x}$-axis) that is increasing the most at the high humidity level. 


\section{Task 2: SOFC Modeling (Task Leader: Brian Koeppel)}

Task 2.1: SOFC Stack Modeling Tools (Kevin Lai, Brian J Koeppel, Khushbu Agarwal, Poorva Sharma)

\section{Task 2.1.1 Reduced Order Model (ROM)}

Milestone: Improved ROM error estimation and verification

Milestone status: Complete.

Summary: The REVEAL framework provides reduced order model (ROM) generation capability for the SOFC stack simulator. The ROMs (or stack emulators) are generated as CAPE-Open (CO) compliant or ACM (Aspen Custom Format) modules which can then be plugged in larger scale system simulations. However, when generating such reduced order models, it is imperative to be able to validate and verify the accuracy of the emulator. During this last quarter we developed an approach that facilitates data verification by allowing the user to 1) provide input parameter values for test cases, 2) run the test cases using the base SOFC simulation code (e.g. SOFC-MP 2D), and 3) compare these results to the predicted results from the generated emulator.

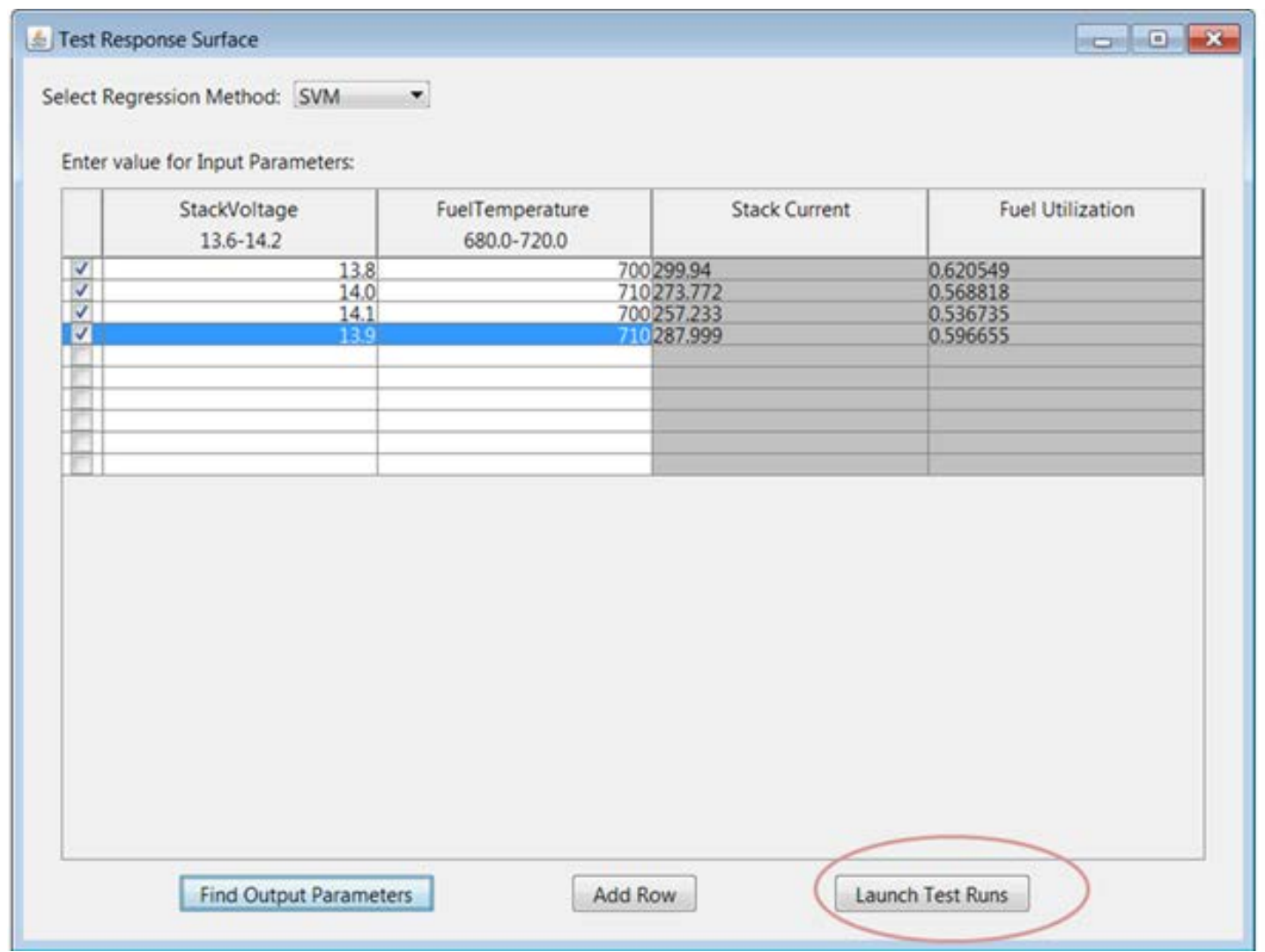

Figure 2.1.1. User provides input parameter values and selects test cases to run. 
Figure 2.1.1 shows the user interface for providing simulation inputs and generating simulation cases. Figure 2.1.2 demonstrates the user workspace as jobs are submitted and results become available on the local machine. The user can select the "Rom Test Results" option in the Visual Analysis section to compare the actual versus predicted results (including any of the regression methods that the ROM has been built with) and calculates the relative error (Figure 2.1.3). This allows the user to simply rerun and test specific cases of interest to assess the accuracy of the derived ROM and suitability for export to the system level modelers.

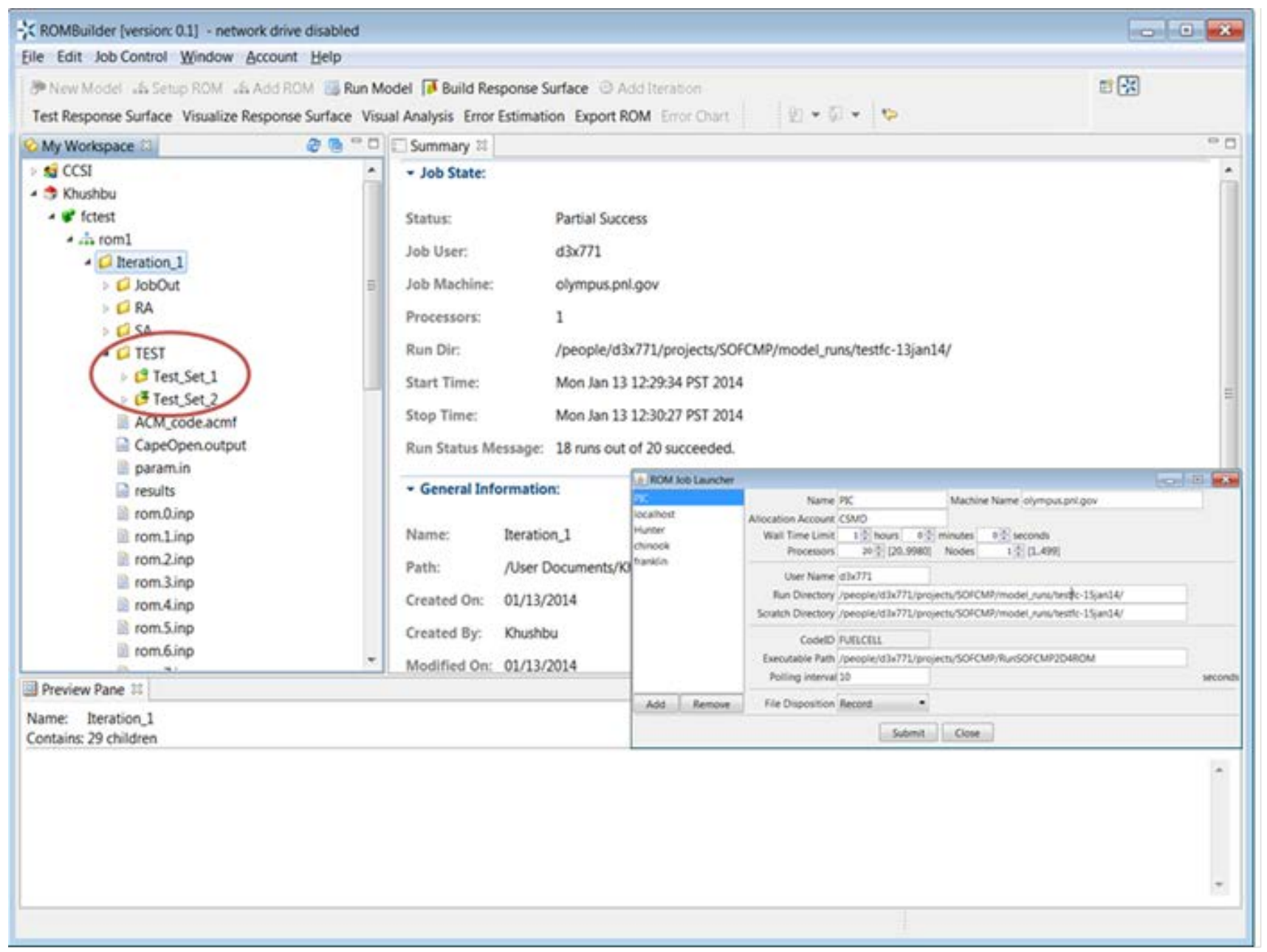

Figure 2.1.2. User workspace and job submission window. 


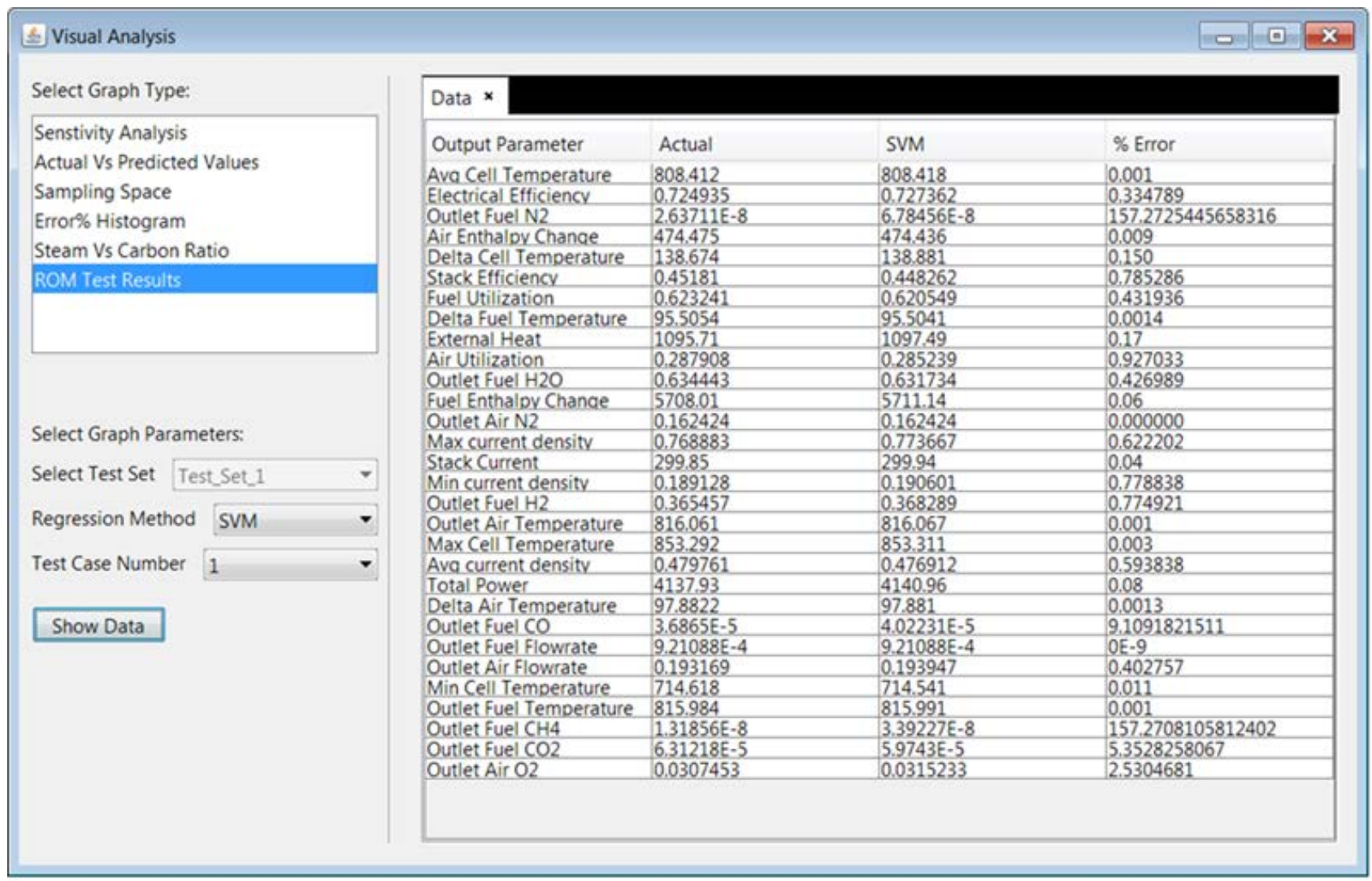

Figure 2.1.3. Visual Analysis- Actual versus predicted results window.

\section{Other Activities:}

\section{Highlight \#1- Improvement of error analysis for ROM accuracy}

The ROM generation process includes an error evaluation step to assess the accuracy of the resulting ROM. This quarter we also implemented the $\mathrm{k}$-fold $(\mathrm{k}=5)$ cross validation technique for calculating ROM accuracy. The k-fold approach is faster and scalable for a larger number of iterations by performing only a maximum of $\mathrm{k}+1$ number of regressions to calculate the ROM accuracy. The 1-off cross validation approach that was implemented previously had a scalability of $\mathrm{O}(\mathrm{N})$, meaning that the computation time scaled linearly with the number of simulation steps $\mathrm{N}$. This was too computationally expensive for the more complex SOFC models being evaluated with a large number of cases, so the improved error estimation approach greatly speeded up the error analysis step for SECA's expected usage.

\section{Task 2.1.3 SOFC-MP 3D}

Milestone: 3D SOFC-MP Temperature Loading for Structural FEA Models

Milestone status: Complete.

Summary: Providing an integrated structural FEA capability has been the ultimate goal for the SOFC stack modeling tool development. A major milestone has been achieved in the last quarter. 
The SOFC-MP 3D module is now able to generate temperature distributions on all SOFC stack components and has been tested for several different FEA models.

In the past, the temperature distribution was only available for MSC-Marc FEM models using the legacy MSC-Marc Mentat-FC user interface. During the last few quarters, improvements have been made on SOFC-MP 3D so that two popular commercial finite element analysis (FEA) models, e.g., ANSYS and ABAQUS FEA models are supported. For pre-processing, both ANSYS and ABAQUS FEA models can be read directly and processed by the SOFC-MP 3D module. For post-processing, the SOFC-MP 3D module can now generate temperature distribution files in either ANSYS or ABAQUS native format for all original nodes and for all components in the source model.
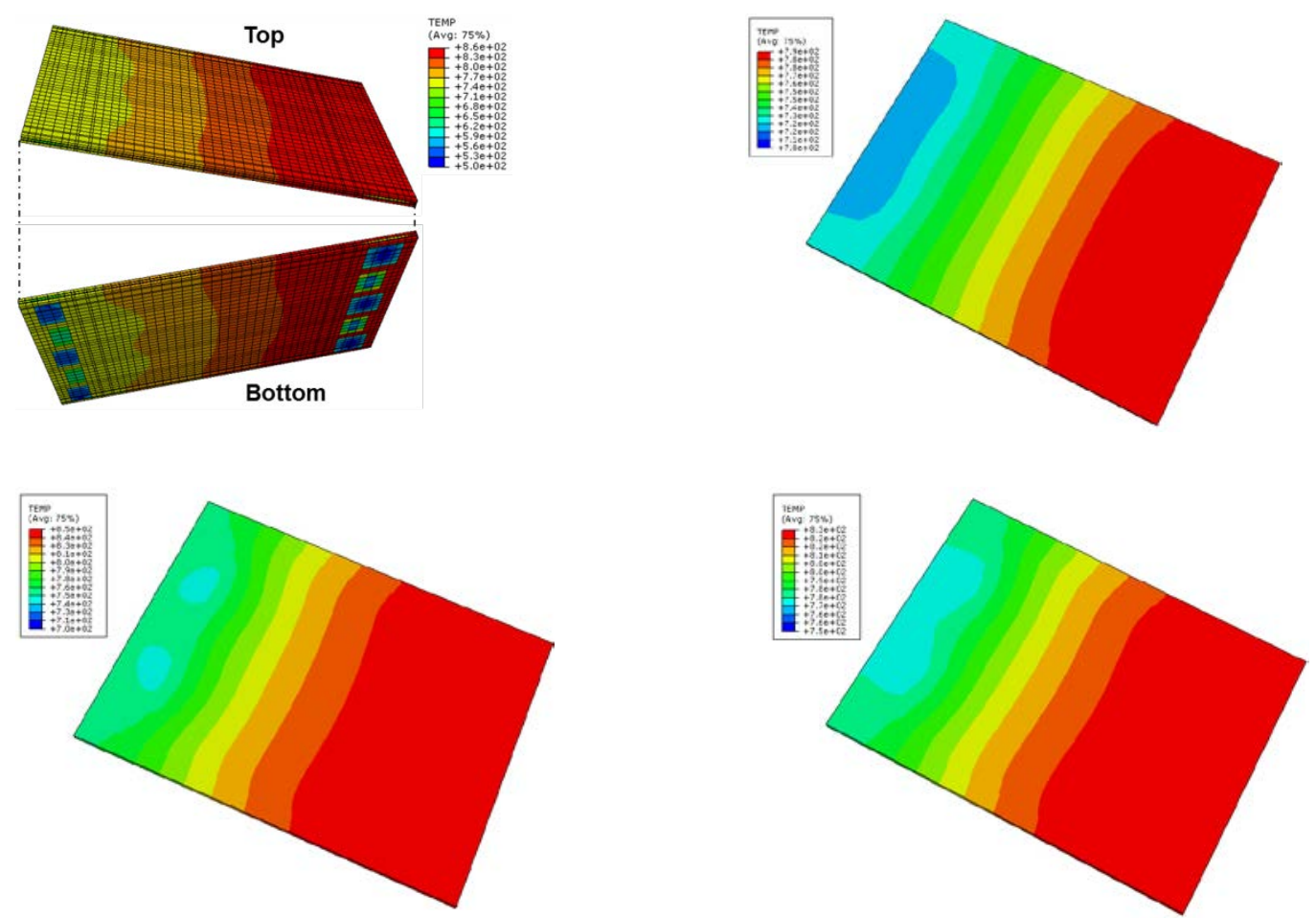

Figure 2.1.4. Temperature contours of the SOFC stacks under different power operation conditions.

The improved SOFC-MP 3D tool has supported the modeling studies for the PNNL test stack and viscous seal engineering analysis (Task 2.2.1). In the parametric study numerous 3D simulations have been performed with the following different operating conditions:

1. Boundary conditions: adiabatic, furnace, and insulated conditions.

2. Fuel types: hydrogen fuel and methane fuel

3. Fuel utilizations: low power operation (21\%) and high power operation (75\%) 
Figure 2.1.4 illustrates ABAQUS displaying temperature contour plots with temperature data generated by the SOFC-MP 3D module. Detailed structural analysis has been summarized in this quarterly report for Task 2.2.1.

Further study will be carried out to achieve a seamless integrated structural FEA capability.

\section{Other Activities:}

\section{Highlight \#1- Benchmark 3D SOFC-MP module (with high methane)}

Comparisons with benchmark cases or experimental data are necessary to ensure that proper physics are adequately captured in the SOFC-MP 3D module. As previously stated, benchmarks performed under the IEA program (Achenbach 1996) were determined to be the best available model data from the literature.

Fully capturing all aspects of multi-physics in 3D simulations on mixed fuel containing methane was more challenging. For hydrogen only fuel, the fuel flow molar volume remains the same when hydrogen is oxidized. A model with methane reforming introduces extra complexity because the on-cell steam reforming reaction generates additional moles in the fuel flow and thus the extra volumetric expansion. The SOFC-MP 3D tool calculates the $\mathrm{CH}_{4}$ reforming rate, adjusts species concentration as methane is consumed in the flow, and manages volumetric expansions resulted from the reforming. This extra physics phenomenon introduces additional computational effort to the already complex multi-physics computations.

Three-dimensional models have been developed according to the specifications in Achenbach's paper. Information on geometry, flow and electrochemistry parameters has been obtained from the original paper. Some details missing in the original paper have been collected through references citing the same paper. Our models have been built to match these numerical experiments as close as possible. Since the SOFC-MP model includes the entire stack domain, the edge conditions will be inherently different from the benchmark which only considered the active area of the cell. This is an unavoidable difference in the modeling approach since the 3D SOFC-MP is more detailed, but it is not expected to significantly alter the results and trends.

In the last quarter, preliminary results for all three flow configurations showed that simulation results on current density, fuel and air temperature compared well with the data presented by Achenbach. More detailed validation results are presented here. Figure 2.1.5 to Figure 2.1.7 show quantitative data comparisons on all quantities of interest (QOIs): distributions of temperature, species fractions, current density, etc., for all three planar SOFC configurations with $\mathrm{CH}_{4}$-based fuels: co-flow, counter-flow, and cross-flow. The comparison metrics looks very good on both the co-flow and counter-flow cases. For the cross-flow (Figure 2.1.7), much has been improved, but there is still a significant discrepancy for this difficult model. The differences are attributed to the thermal influence of the surrounding manifold structure on the localized peak value for these quantities; however, this match to the benchmark is deemed to be acceptable. The SOFC-MP model has inherently more detail and more realistic heat transfer than the original benchmark which affects the highly localized peak values near the edges of the active area. The overall field distribution is still similar though. Therefore, the SOFC-MP results are expected to be more realistic to the results of testing with an actual cell of this design. 


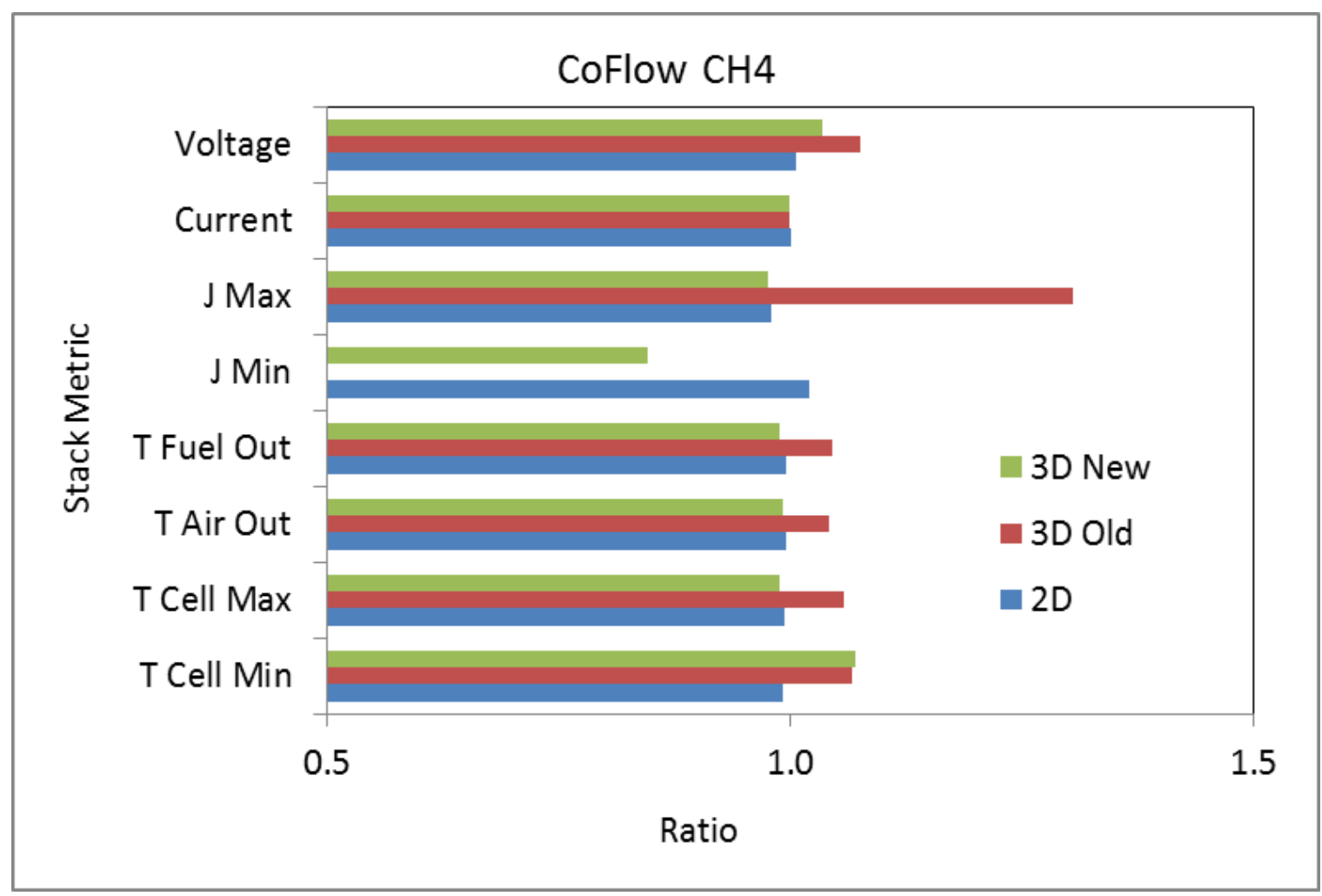

Figure 2.1.5. Benchmark metric comparison: Co-Flow methane fuel.

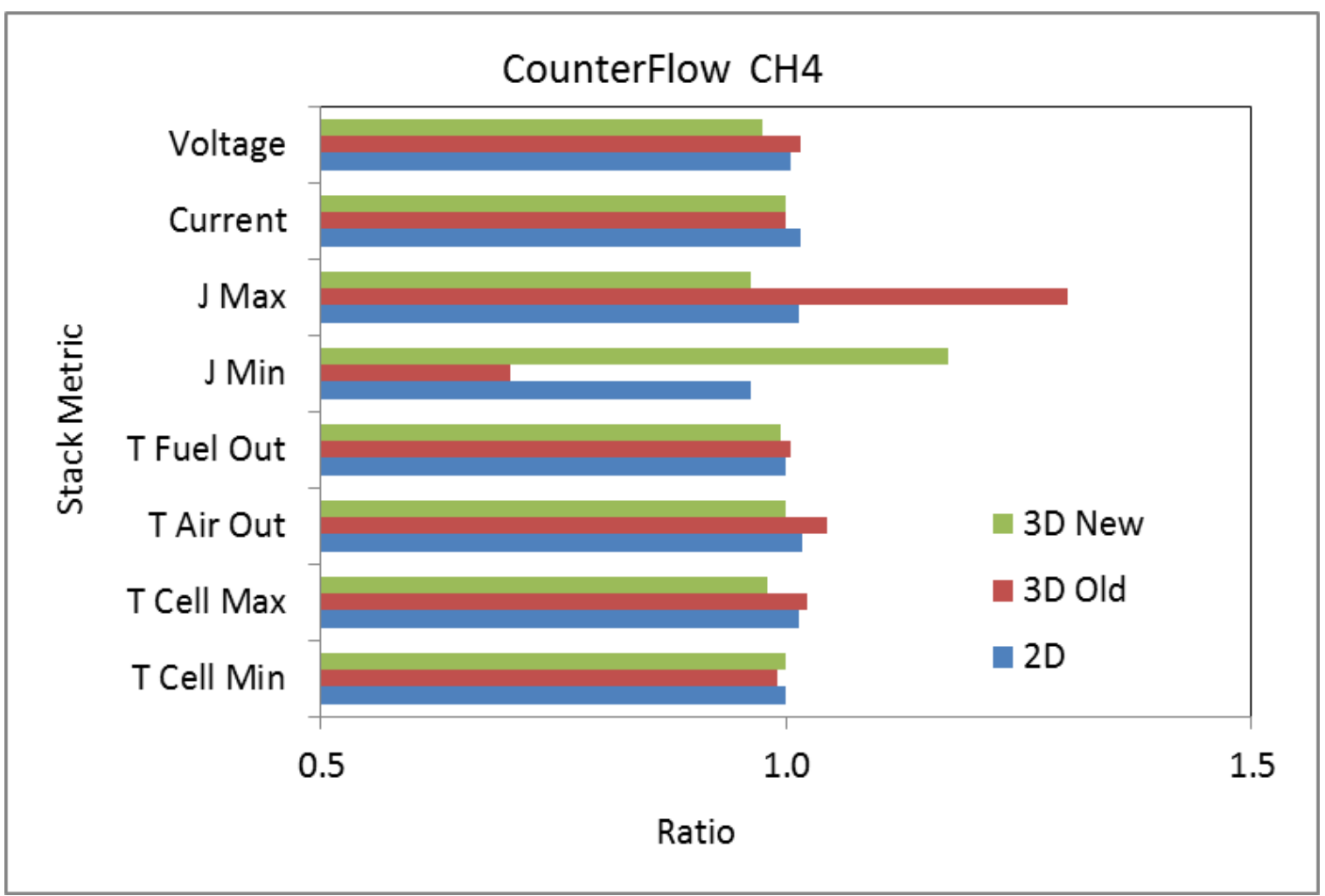

Figure 2.1.6. Benchmark metric comparison: Counter-Flow methane fuel. 


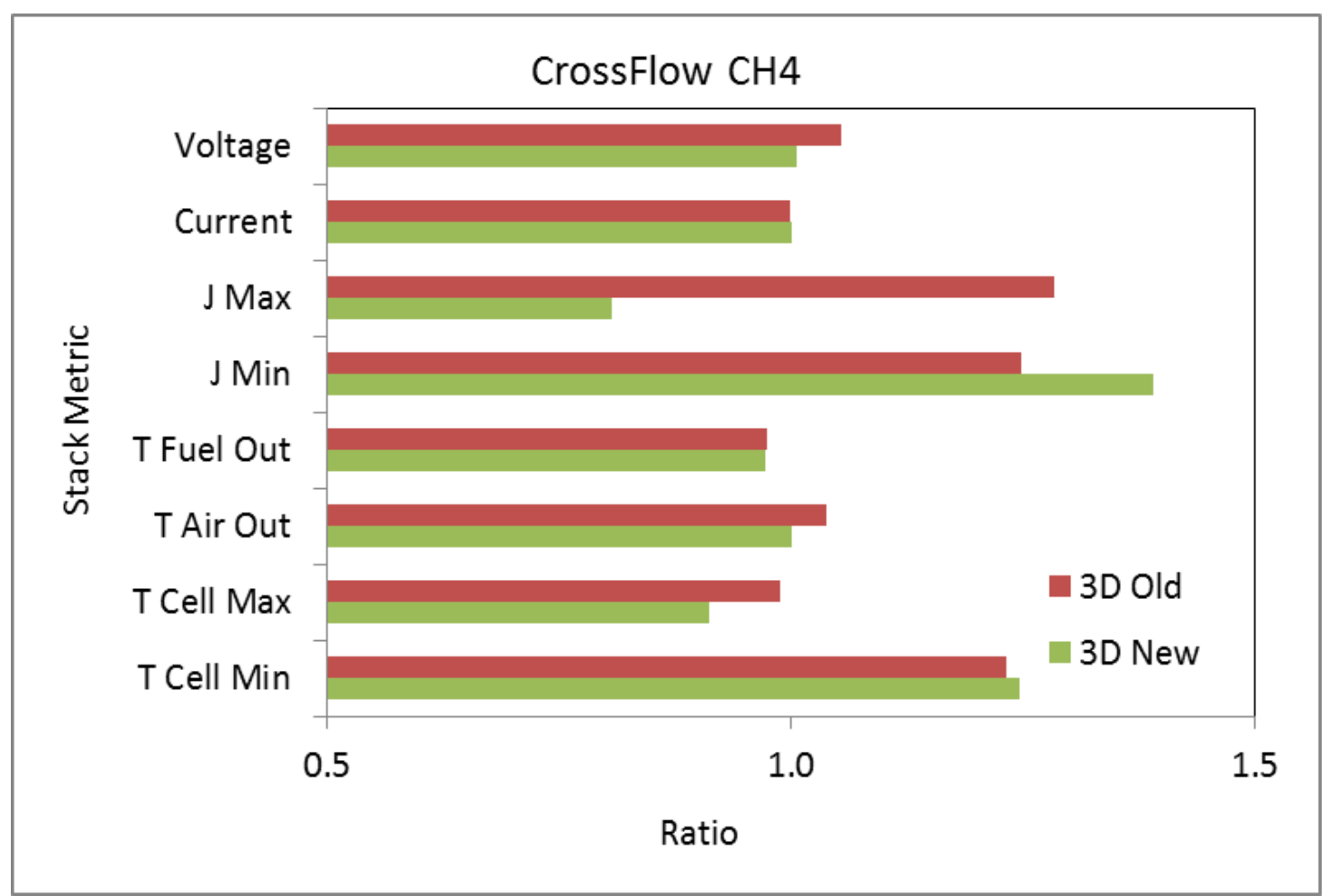

Figure 2.1.7. Benchmark metric comparison: Cross-Flow methane fuel.

Highlight \#2- Further improvement of the SOFC-MP 3D module

Two major enhancements are being implemented in SOFC-MP 3D module.

1. State variable computations

2. Cell-to-cell variations

Both are valuable features that have already been implemented in the $2 \mathrm{D}$ tool and will also greatly improve the 3D simulation of realistic stack operations and testing. The state variable computation will be able to facilitate long term degradation analysis, while the cell-to-cell variation will simulate some off-normal operating conditions such as short circuit or flow blockage. Both features are in progress and they are expected to be finished in the next two quarters.

\section{Task 2.1.4 SOFC-MP Framework}

\section{Milestone: None}

\section{Other Activities:}

Highlight \#1- Further improvement of the SOFC-MP GUI

Two enhancements have been implemented in the SOFC-MP GUI in the last quarter:

1. Support for multi-cell stacks.

The GUI is now capable of visualizing results for QOIs of different cells.

2. Job control. 
Users can abort the simulation, or stop the iteration and start the post-processing when the convergence criteria have not yet been met. As shown in Figure 2.1.8, this flexibility is valuable when a user desires to check the result before a simulation runs its full course (which could be hours).

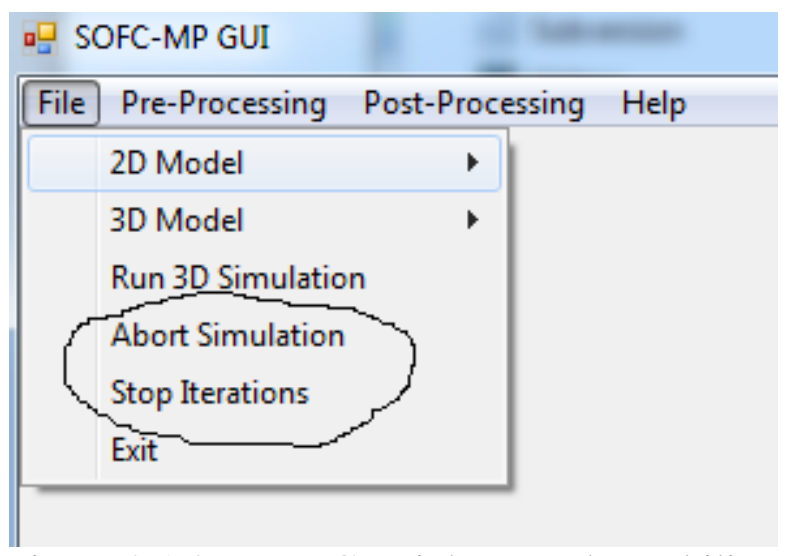

Figure 2.1.8. New GUI job control capability.

Task 2.2: Thermal-Mechanical Modeling for Reliable Stack Components (Wei 'Wesley' $\underline{\mathrm{Xu}, \text { Zhijie 'Jay' Xu, Elizabeth Stephens, Brian Koeppel) }}$

\section{Task 2.2.1 Constitutive Modeling and Self-Healing Mechanisms of Viscous Seals}

Milestone: Influence of operating conditions on long-term reliability of compliant seals

Milestone Status: Complete

Summary: During the first quarter of FY14, seal modeling work has been continued on investigating the influence of electrochemical operating conditions on the long-term functionality and reliability of the compliant glass seal in SOFC stacks. The PNNL previously developed 3D finite element damage-healing glass seal model has been integrated with the SOFC-MP multiphysics solver to include the electrochemically generated heat response into the structural mechanical analysis. The effects of a variety of electrochemical operating parameters such as thermal boundary conditions, fuel composition, and fuel utilization have been examined. The findings can be used to understand the underlying mechanisms of the seal performance degradation within in the in-service SOFC stacks as well as to optimize the operational process and improve the material development. 

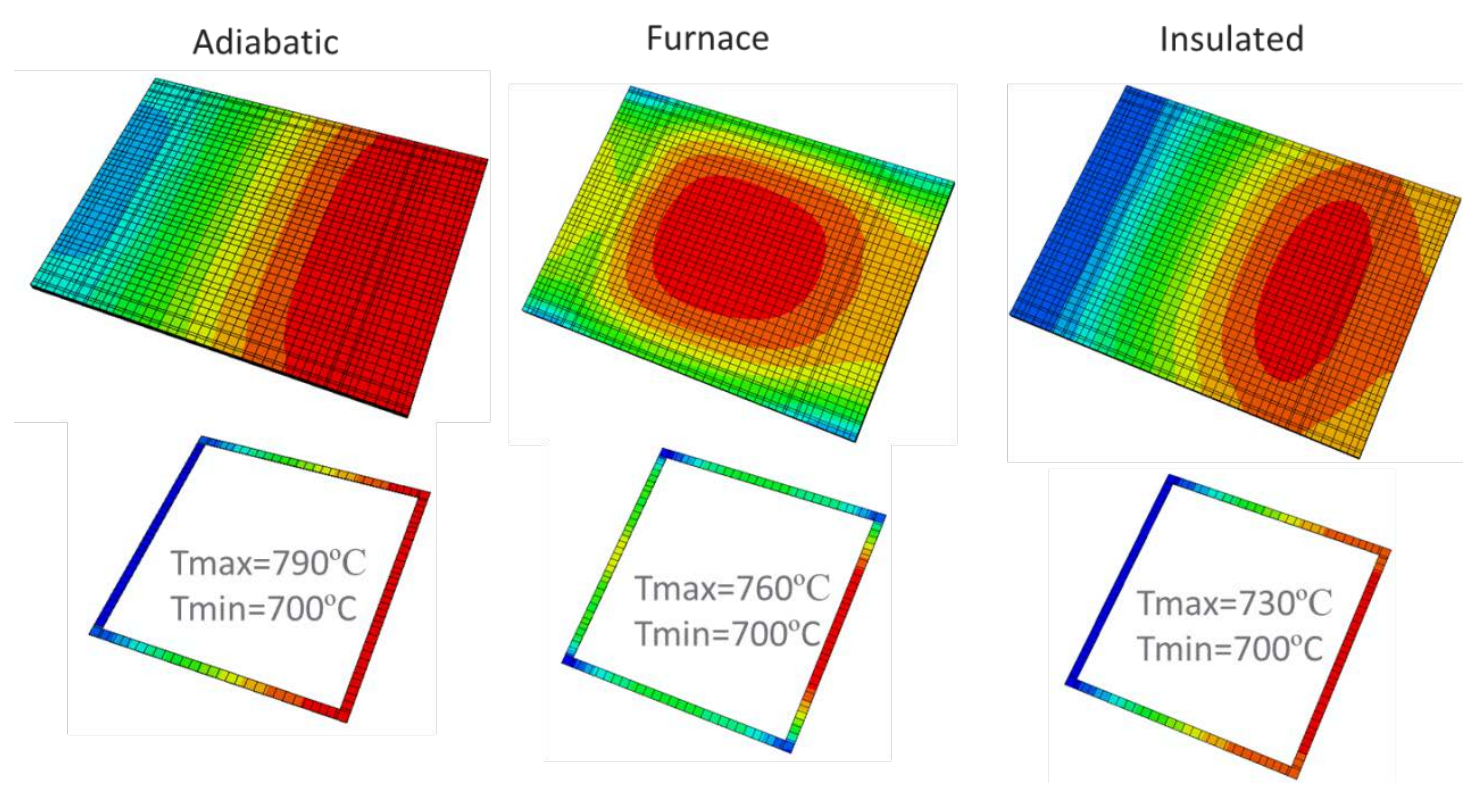

Figure 2.2.9. Temperature contours of the SOFC stack under different thermal conditions

A $10 \times 10 \mathrm{~cm}$ industrial characteristic co-flow SOFC single-cell stack is used in the numerical simulations, in which the fuel and air enter from the left side at a temperature of $700^{\circ} \mathrm{C}$. Three different thermal boundary conditions, i.e. adiabatic, furnace, and insulation have been examined. For the adiabatic condition, no heat transfer is allowed between the SOFC stack and its surroundings; for the furnace condition, the SOFC stack is assumed to be placed in a constantly heated furnace; and the insulated condition describes a SOFC stack in an enclosure container whose outer boundaries are kept at room temperatures with a low thermal conductivity insulation material in between.

The steady-state temperature distribution contours of the SOFC stack in the aforementioned three cases are shown in Figure 2.2.9. It can be observed that unlike the adiabatic thermal conditions where the temperature increases from the left to right with the boundaries having the extreme values, the cases of furnace and insulated conditions appear to have the heated zone located in the central region of the stack and the temperature decreases outwards from there due to the heat transfer activities between the SOFC stack and its enclosure. In addition, it is also noticed that the SOFC stack under furnace or adiabatic thermal conditions generally have a lower temperature field and a narrow temperature difference across the domain. Because the driving force for the structural damage in seals typically comes from the thermal stresses induced by mismatch of coefficient of thermal expansion, a more uniform temperature field is likely to result in a more homogeneous damage distribution within the seal which can be seen in Figure 2.2.10. 

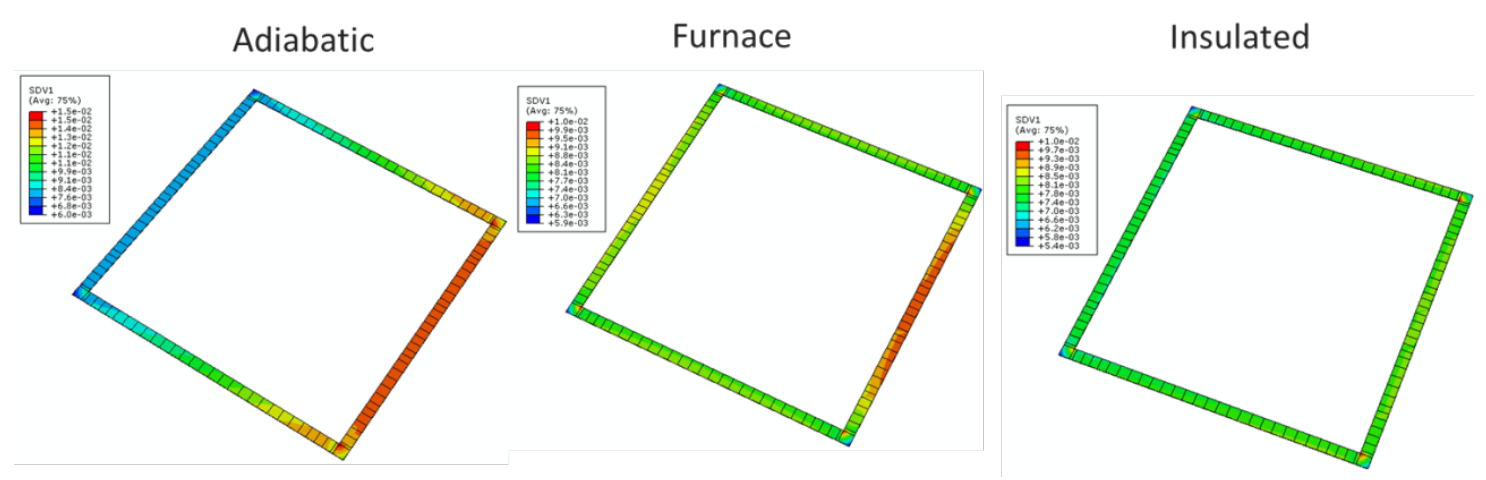

Figure 2.2.10. Damage contours of the glass sealants for different SOFC thermal conditions

The evolution of volume-average structural damages in terms of cracking damage and pore damage within the glass sealant under the three different thermal boundary conditions are plotted in Figure 2.2.11. All three cases have produced a quite similar damage evolving history although because of the comparatively colder environment the non-adiabatic cases (furnace and insulated thermal conditions) lead to slower healing upon heat treatment and slightly lower pore damage accumulation due to the decay of the viscous flow.

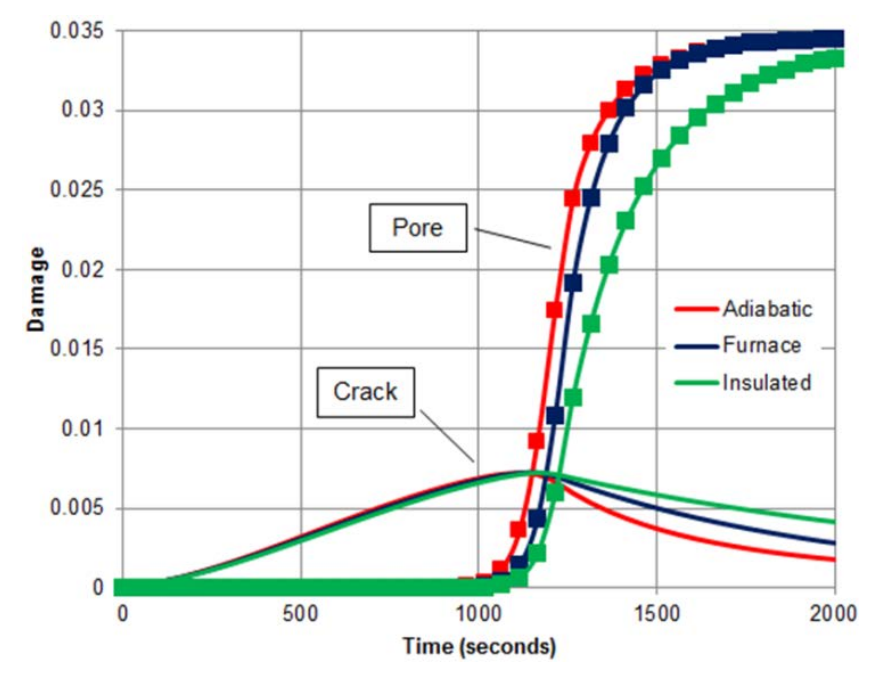

Figure 2.2.11. Average structure damage evolution within the SOFC stack

Fuel utilization is another crucial factor in the operation of SOFC stacks and could be important to the performance of glass sealants under thermal cycling conditions. Although high power operation is able to enhance the fuel utilization efficiency and generate more power output is thus preferred, the influence of such aggressive treatment on the structural integrity of the SOFC stack, glass sealants in particular, remains to be in doubt. In the current study, two cases with different fuel utilization ratios (\%FU: $21 \%$ and $75 \%$ ) have been compared and analyzed. Figure 2.2.12 shows the temperature contours under these two operating conditions. It can be seen that although the heat maps in these two cases appear to have very similar patterns, the maximum temperatures and temperature gradients in the two fields are significantly different as the former are $60^{\circ} \mathrm{C}$ lower than the latter, which therefore affects the mechanical degradation performance 
of the glass sealant during thermal cycling. As presented in Figure 2.2.13, low power electrochemical operation yields relatively lower damages while requiring longer time to complete the crack healing.

Low Power Operation (\%FU: 21\%)

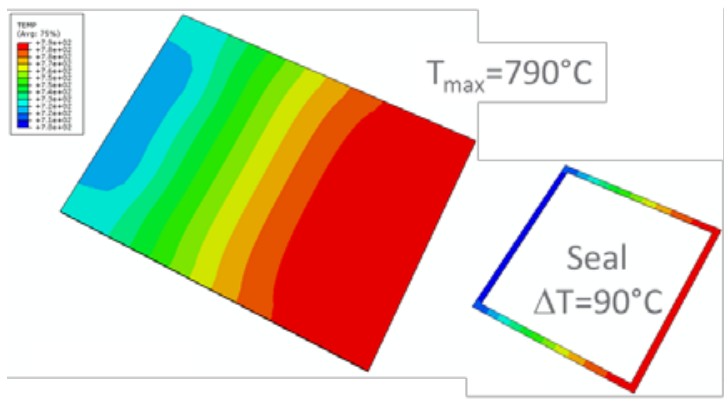

High Power Operation (\%FU: 75\%)

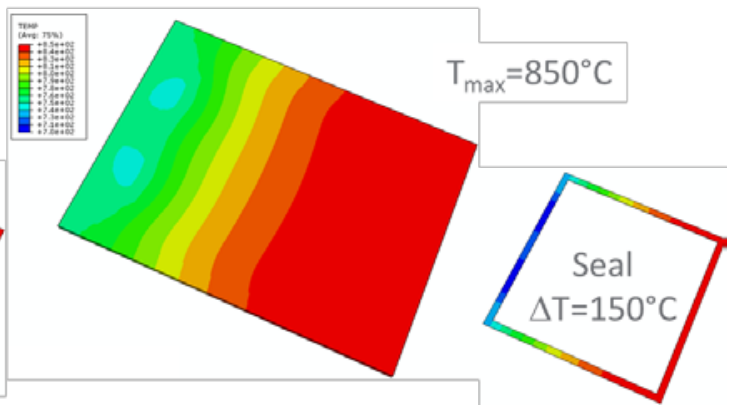

Figure 2.2.12. Temperature contours of the SOFC stacks under different power operation conditions

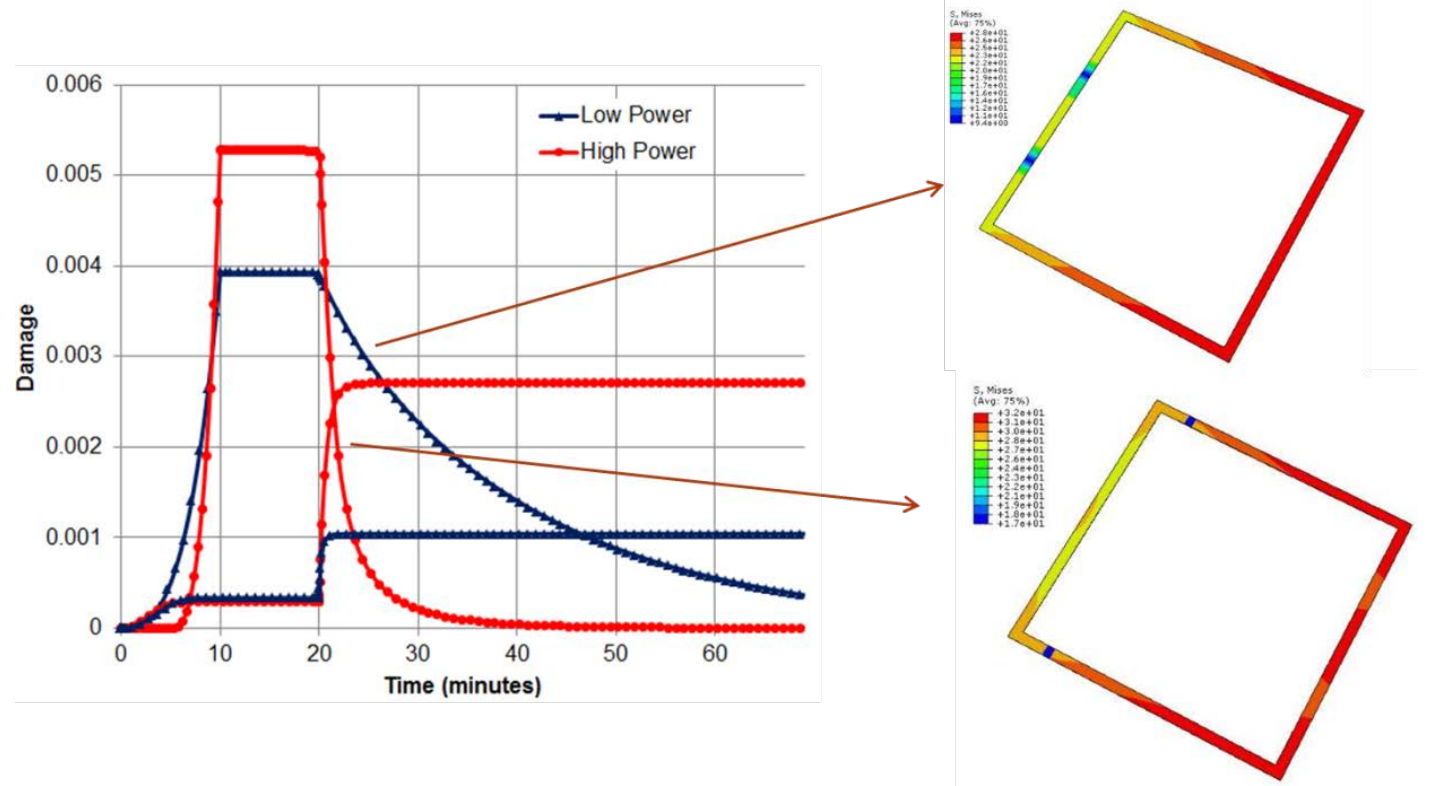

Figure 2.2.13. Damage responses of the glass sealant for different SOFC power operation conditions

Figure 2.2.14 shows the differences in temperature profiles caused by fuel compositions. Compared to the hydrogen-only fuel, methane-based fuel tends to generate a more uniform heat map for this model. The gradual temperature gradient further leads to a more homogeneous stress field upon cooling, and slightly reduces the thermal stress induced damages as revealed in Figure 2.2.15. Therefore, these modeling tools show the capability to predict possible seal damage under realistic operating conditions by linking with SOFC-MP 3D. 
Hydrogen-Fuel

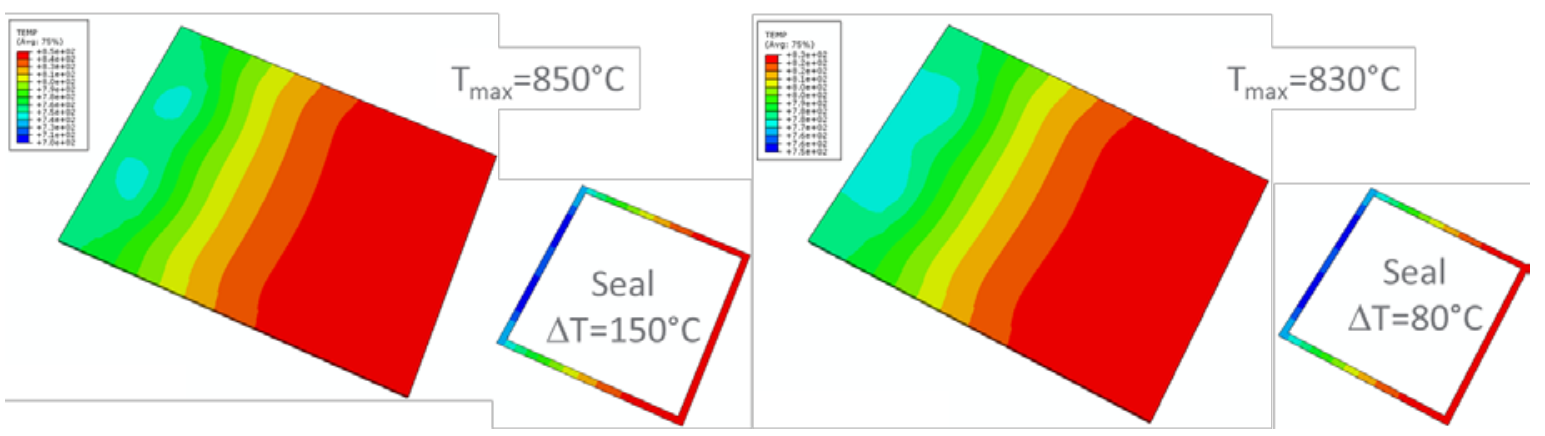

Figure 2.2.14. Temperature contours of the SOFC stacks operated with different fuels
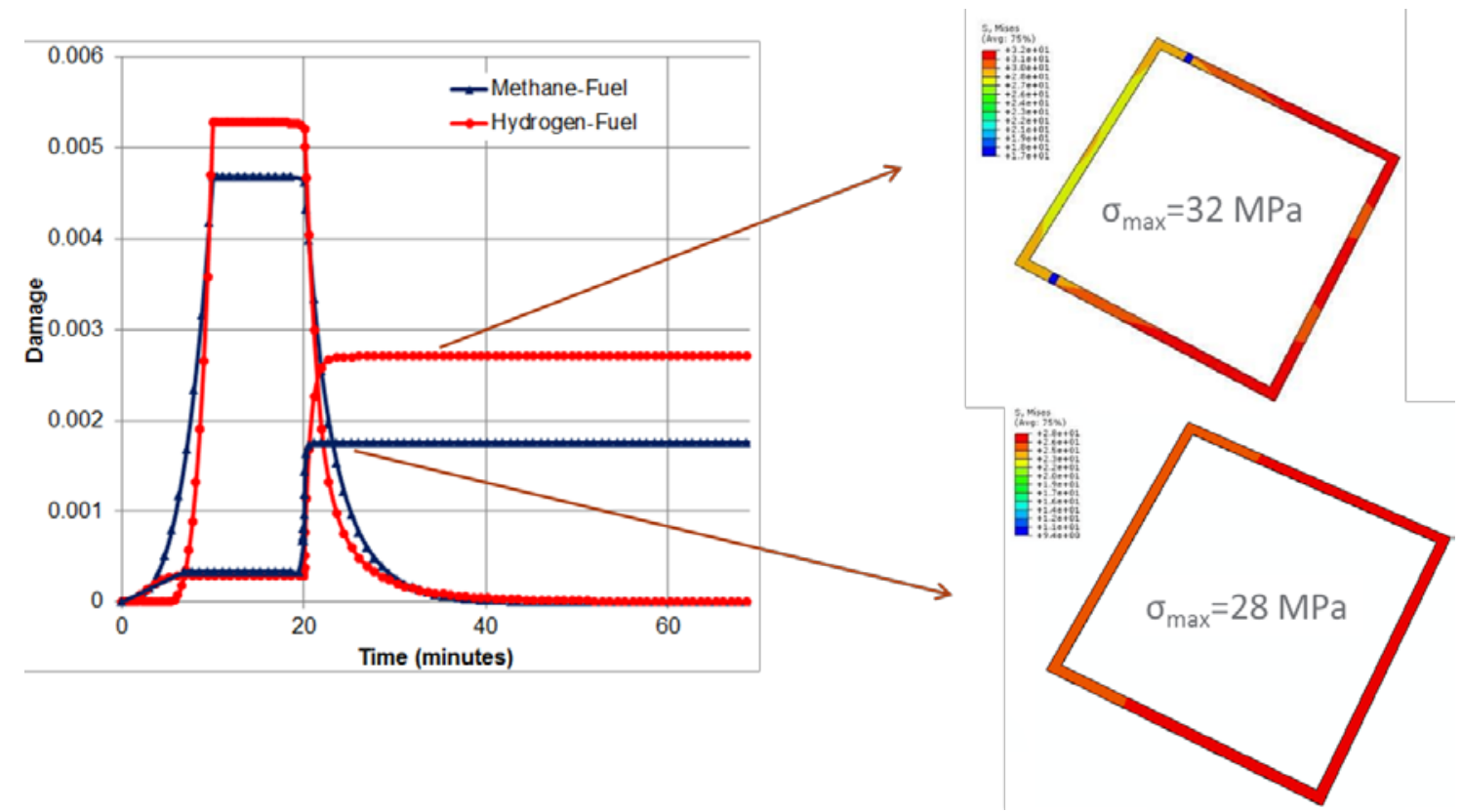

Figure 2.2.15. Damage responses of the glass sealant for the SOFC stacks operated with different fuels

\section{Task 2.2.2: Modeling of Scale Adherence and Lifetime of Metallic Interconnect}

Milestone: Effect of coating thickness/properties on interconnect strength/life prediction.

Milestone status: Complete

Summary: The IC model methodology was modified using interfacial indentation data to characterize the effects of surface modifications on scale failure and interconnect lifetime. The first version of modified IC model does not consider the effect of coating on the interconnect strength and life prediction. The improved IC model is presented here to demonstrate the effect of coating on the strength and life. 
Thermal stress in coating, scale, and substrate during the isothermal cooling

First, we have identified the thermal stress in each layer (Figure 2.2.16) according to theory of elasticity, where

$$
\begin{aligned}
& \sigma_{1}=E_{1} \frac{E_{3} h_{3}\left(\alpha_{1}-\alpha_{3}\right)+E_{2} h_{2}\left(\alpha_{1}-\alpha_{2}\right)}{E_{1} h_{1}+E_{2} h_{2}+E_{3} h_{3}} \Delta T \text { (Coating) } \\
& \sigma_{2}=E_{2} \frac{E_{1} h_{1}\left(\alpha_{1}-\alpha_{2}\right)+E_{3} h_{3}\left(\alpha_{3}-\alpha_{2}\right)}{E_{1} h_{1}+E_{2} h_{2}+E_{3} h_{3}} \Delta T \text { (Scale) } \\
& \sigma_{3}=E_{3} \frac{E_{1} h_{1}\left(\alpha_{3}-\alpha_{1}\right)+E_{2} h_{2}\left(\alpha_{3}-\alpha_{2}\right)}{E_{1} h_{1}+E_{2} h_{2}+E_{3} h_{3}} \Delta T \text { (Substrate) }
\end{aligned}
$$

$E_{i}=\frac{E_{i}^{*}}{1-v_{i}}$ is the modulus for plain stress with $\mathrm{i}=1,2,3$ representing the coating, scale, and substrate, respectively. $E_{i}^{*}$ is the Young's modulus for each layer. $h_{i}$ is the thickness for each layer. $\alpha_{i}$ is the thermal expansion coefficients for each layer. $\Delta T$ is the temperature change during the thermal cycle. With chosen material parameters we can quantitatively estimate the thermal stresses in the coating, scale, and substrate.

We concluded that during the buckling driver delamination (Figure 2.2.17), the coating will be elongated and this change in the elastic energy of coating should be incorporated into the calculations of overall energy release rate. On the other hand, existence of the coating will increase the critical buckling stress for the scale. The combined effect from these two factors is expected to significantly govern the effect of coating on the critical thickness of the scale and the life of the interconnect.

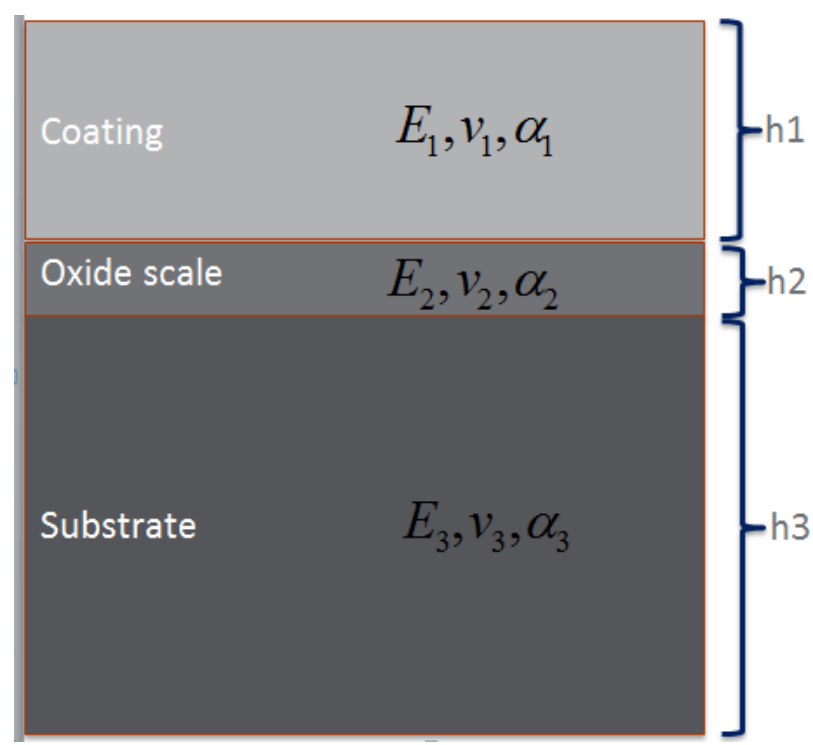

Figure 2.2.16. Layers for the interconnect delamination model 


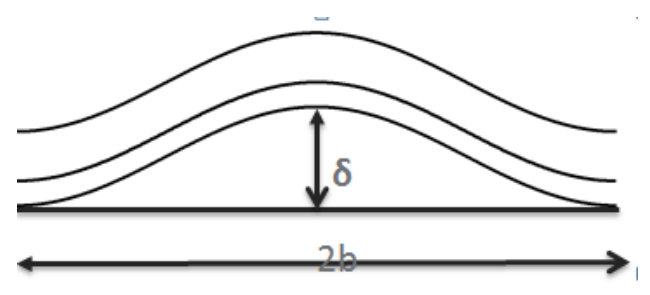

Substrate

Figure 2.2.17. Spallation buckling mode of the oxide scale and protective coating

\section{Modified energy release rate considering the effect of coating}

The effect of coating on the interconnect life can be systematically investigated through modifying our previous IC model to incorporate the effect of coating into the energy release rate calculation. With given stress applied to the oxide scale layer and critical buckling stress, the buckling deflection $\delta$ can be written as,

$$
\delta^{2}=\frac{16 b^{2}}{\pi^{2}} \frac{\left(1-v_{2}^{2}\right)}{E_{2}}\left(\sigma_{2}-\sigma_{c}\right)
$$

The tensile strain within the coating layer due to the buckling can be written as

$$
\varepsilon^{*}=\frac{1}{2 b}\left(\frac{1}{2} \int_{-b}^{b} w^{\prime 2} d y\right)=\frac{\pi^{2}}{16 b^{2}} \delta^{2}
$$

The original thermal strain in the coating layer is

$$
\varepsilon_{1}=\frac{1-v_{1}^{2}}{E_{1}} \sigma_{1}
$$

Therefore, the elastic strain energy within the coating layer is

$$
S_{e}=\frac{1}{2} \frac{E_{1}}{1-v_{1}^{2}}\left[\left(\varepsilon^{*}+\varepsilon_{1}\right)^{2}-\varepsilon_{1}^{2}\right] 2 b h_{1}
$$

The original strain release rate without the coating layer is

$$
G^{0}=\frac{\left(1-v_{2}^{2}\right) h_{2}}{2 E_{2}}\left(\sigma_{2}-\sigma_{c}\right)\left(\sigma_{2}+3 \sigma_{c}\right)
$$

The corresponding strain energy release rate is

$$
G=G^{0}-\frac{1}{2} \frac{\partial S_{e}}{\partial b}=\frac{1}{2} \frac{1-v_{2}^{2}}{E_{2}}\left(\sigma_{2}-\sigma_{c}\right)\left[h_{2}\left(\sigma_{2}+3 \sigma_{c}\right)-\frac{E_{1}}{E_{2}} \frac{1-v_{2}^{2}}{1-v_{1}^{2}} h_{1}\left(\sigma_{2}-\sigma_{c}\right)-2 \sigma_{1} h_{1}\right]
$$

Where the buckling stress of scale can be estimated to be: 


$$
\sigma_{c}=\frac{\pi^{2}}{12} \frac{E_{2}}{1-v_{2}^{2}}\left(\frac{h_{1}+h_{2}}{b}\right)^{2} \frac{h_{1}+h_{2}}{h_{2}}
$$

\section{Parametric study and the effect of coating on the strength and life}

In this section, a systematic parametric study was performed to investigate the effect of different parameters on the interconnect strength and life. The material parameters used in the benchmark model were listed in Table 2.2.1. Specifically, we will investigate the effect of interface toughness $\mathrm{K}_{\mathrm{I}}$, the coating thickness $\mathrm{h}_{1}$, and the coefficient of thermal expansion on the critical oxide scale thickness hc.

Table 2.2.1 IC Model Material Properties

\begin{tabular}{|l|l|l|l|}
\hline symbol & Physical meaning & value & unit \\
\hline$E_{3}$ & Young's Modulus (Substrate) & 200 & $G P_{a}$ \\
\hline$E_{2}$ & Young's Modulus (Oxide) & 250 & $G P_{a}$ \\
\hline$E_{1}$ & Young's Modulus (Coating) & 124.7 & $G P_{a}$ \\
\hline$v_{3}$ & Poisson Ratio (Substrate) & 0.3 & Dimensionless \\
\hline$v_{2}$ & Poisson Ratio (Oxide) & 0.27 & Dimensionless \\
\hline$v_{1}$ & Poisson Ratio (Coating) & 0.36 & Dimensionless \\
\hline$\alpha_{3}$ & Coefficient of Thermal Expansion (Substrate) & $12.4 \times 10^{-6}$ & $1 / K$ \\
\hline$\alpha_{2}$ & Coefficient of Thermal Expansion (Oxide) & $5.7 \times 10^{-6}$ & $1 / K$ \\
\hline$\alpha_{1}$ & Coefficient of Thermal Expansion (Coating) & $11.5 \times 10^{-6}$ & $1 / K$ \\
\hline$h_{3}$ & Thickness (Coating) & $0.5 \times 10^{-3}$ & $\mathrm{~m}$ \\
\hline$h_{1}$ & Thickness (Substrate) & $15 \times 10^{-6}$ & $\mathrm{~m}$ \\
\hline$K_{I}$ & Interface Fracture Toughness (Mode I) & 1.8 & $M P_{a} \cdot \sqrt{m}$ \\
\hline$\Delta T$ & Temperature Difference & 775 & $\mathrm{~K}$ \\
\hline
\end{tabular}

1. The effect of interface toughness $\mathrm{K}_{\mathrm{I}}$ 


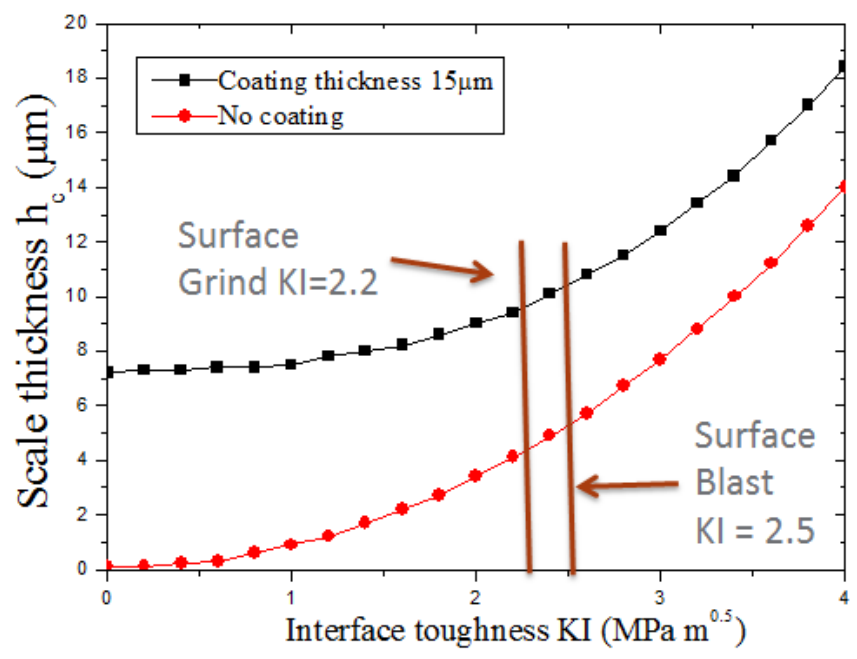

Figure 2.2.18. Effect of interface toughness on critical scale thickness.

The interface toughness has significant effect on the critical scale thickness (the maximum thickness scale can grow before fails) as shown in Figure 2.2.18. hc is proportional to the scale strength. The larger hc means the stronger the scale and the longer the interconnect life. For scales with and without a coating, the critical scale thickness hc increases monotonically with interface toughness $\mathrm{K}_{\mathrm{I}}$. Since $\mathrm{K}_{\mathrm{I}}$ for surface blast is slightly greater than that of surface grind, there will be around $\sim 1 \mu \mathrm{m}$ increase of hc from surface grind to surface blast. For surface grind with coating, the critical thickness is about $4 \mu \mathrm{m}$ w/o coating and about $10 \mu \mathrm{m}$ with $15 \mu \mathrm{m}$ thickness of coating.

2. The effect of coating thickness

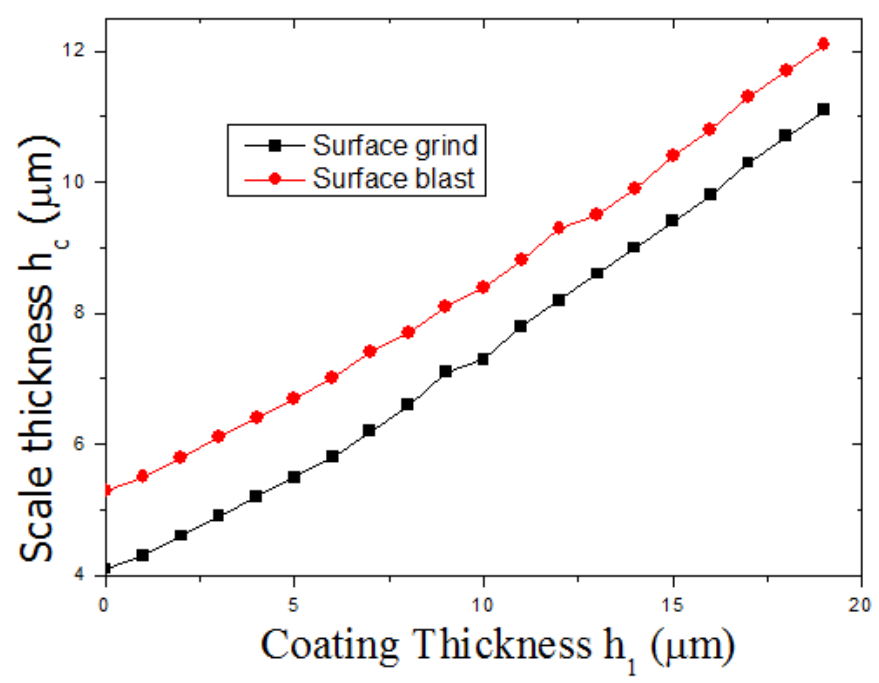

Figure 2.2.19. Effect of coating thickness on critical scale thickness.

By varying the coating thickness $h_{1}$, effect of coating thickness on the critical scale thickness is presented in Figure 2.2.19. For both surface grind and surface blast, the critical scale thickness 
hc (the strength of scale) increases with increasing coating thickness. This is because the elastic stretch in the coating layer adsorbs part of the energy released from fracturing. On the other hand, increase in the critical bucking stress leads to a smaller energy release rate $\mathrm{G}$, which is also beneficial to the scale strength. Therefore, the coating provides extra mechanical benefits to the scale strength and increases interconnect life through i) adsorbing elastic energy released from fracturing ii) providing addition structure constraint to the scale to increase the buckling stress.

3. The effect of coefficient of thermal expansion (CTE)

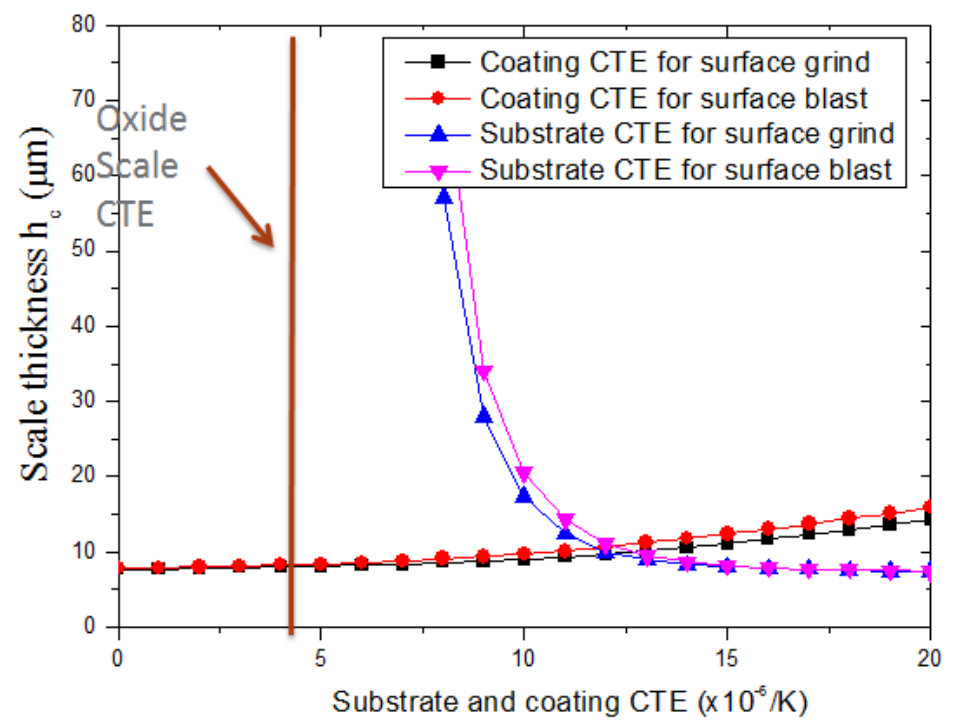

Figure 2.2.20. Effect of coefficient of thermal expansion on critical scale thickness.

By varying the coefficients of thermal expansion of coating $\left(\alpha_{1}\right)$ and substrate $\left(\alpha_{3}\right)$, the effect on the critical scale thickness is shown in Figure 2.2.20. The coating CTE does not have any pronounced effect. hc only slightly increases with increasing coating CTE $\alpha_{1}$. However, with substrate CTE $\alpha_{3}$ approaching the oxide scale CTE $\alpha_{2}$, as indicated in the Figure, the critical scale thickness is significantly increasing. This is because the thermal stress in oxide scales originates from the mismatch CTEs between the scale and substrate. The matching CTEs will reduce the thermal stress in the scale and increase the interconnect life.

\section{Task 2.3: Electrochemistry and Degradation Modeling}

\section{Milestone: None}

\section{Other Activities:}

\section{Highlight \#1- Boston University Subcontract}

The subcontracting process with Boston University was initiated to collaborate with Dr. Emily Ryan beginning in the next quarter for evaluation of cathode degradation mechanisms under $\mathrm{H}_{2} \mathrm{O}$ and $\mathrm{CO}_{2}$ contaminants. 


\section{Task 3: Experimental Support of Modeling}

Task 3.1: Interfacial Stresses and Degradation of Interconnect Materials (Elizabeth Stephens, Zhijie 'Jay' Xu, Brian Koeppel, Jeff Stevenson)

Milestone: Interfacial analysis methodology validation.

Milestone status: $5 \%$ complete.

Summary: In Q1, candidate material and coating systems were identified to aid in the validation of our interfacial analysis methodology. Efforts were spent in acquiring a European grade steel (S235) that could be vacuum spray coated with $\mathrm{NiCr}$ as characterized in detail by Marot et al. In addition to Marot et al. reporting the stress intensity factor and parameters determined during interfacial analysis, a varying range of coating thicknesses, substrate thicknesses, and substrate surface roughness were investigated (Table 3.1). This allowed greater flexibility in ensuring characterization of a similar system for validation purposes. However, samples of this particular material were not able to be supplied. Due to the difficulty of acquiring the European steel, a best equivalent U.S. grade steel was identified for substitution and purchased at the end of Q1.

Table 3.1. Marot et al. interfacial analysis results summary of coated S235 steel.

\begin{tabular}{|c|c|c|c|c|c|c|c|}
\hline & \multicolumn{3}{|l|}{ Samples } & \multicolumn{4}{|c|}{ Interfacial indentation test } \\
\hline & Nomenclature & $t(\mu \mathrm{m})$ & $\mathrm{Ra}(\mu \mathrm{m})$ & $P_{\mathrm{c}}(\mathrm{N})$ & $a_{\mathrm{c}}(\mu \mathrm{m})$ & $(E / H)^{1 / 2}$ & $K_{\mathrm{ca}} \mathrm{MPa} \mathrm{m}^{1 / 2}$ \\
\hline 1 & $\mathrm{Ni}-150-2$ & $110 \pm 20$ & $2.3 \pm 0.2$ & 20.09 & 2.10 & 10.71 & 3.75 \\
\hline 2 & $\mathrm{Ni}-300-2$ & $180 \pm 20$ & $2.3 \pm 0.2$ & 52.06 & 12.23 & 10.71 & 5.23 \\
\hline 3 & $\mathrm{Ni}-600-2$ & $480 \pm 20$ & $2.3 \pm 0.2$ & 82.88 & 27.97 & 10.71 & 5.95 \\
\hline 4 & $\mathrm{Ni}-150-4$ & $110 \pm 20$ & $4.5 \pm 0.5$ & 23.19 & 1.94 & 10.71 & 2.79 \\
\hline 5 & $\mathrm{Ni}-300-4$ & $180 \pm 20$ & $4.5 \pm 0.5$ & 76.44 & 23.55 & 10.71 & 5.66 \\
\hline 6 & $\mathrm{Ni}-600-4$ & $480 \pm 20$ & $4.5 \pm 0.5$ & 143.04 & 80.03 & 10.71 & 7.51 \\
\hline 10 & $\mathrm{Ni}-150-6$ & $110 \pm 20$ & $4.5 \pm 0.5$ & 6.91 & 0.38 & 10.71 & 3.35 \\
\hline 11 & $\mathrm{Ni}-300-6$ & $180 \pm 20$ & $4.5 \pm 0.5$ & 39.83 & 7.81 & 10.71 & 4.99 \\
\hline 12 & Ni-600-6 & $480 \pm 20$ & $4.5 \pm 0.5$ & 78.51 & 23.60 & 10.71 & 5.45 \\
\hline
\end{tabular}

G. Marot et al. / Surface \& Coatings Technology 202 (2008) 4411-4416

Substrate characterization and coating of the U.S. grade steel is anticipated to be completed in early Q2. Interfacial analysis will then be performed where the results will be compared to the results obtained by Marot et al.

Task 3.2: Quantification of Compliant Glass Seal Behavior (Elizabeth Stephens, Wei 'Wesley' Xu)

Milestone: Self-healing evaluations for reinforced glass-seal constitutive model.

Milestone status: $95 \%$ complete. 
Summary: In Q1, efforts were spent in quantifying the characteristic dwell time for healing to occur in compliant glass seal materials reinforced with $\mathrm{ZrO}_{2}$ ceramic glass filler in support of Task 2.2A. Controlled, crack healing experiments were performed where glass bar specimens, 4 x $3 \times 23 \mathrm{~mm}$ in geometry, were machined from glass plates fabricated with varying volume fractions of reinforced filler, 7.5, 15, and 22.5 percent (Fig. 3.2.1 and 3.2.2). Two bar specimens were placed vertically into a channeled, test fixture (Fig. 3.2.3) and exposed to elevated test temperatures ranging from 700 to $850^{\circ} \mathrm{C}$ for varying dwell times.

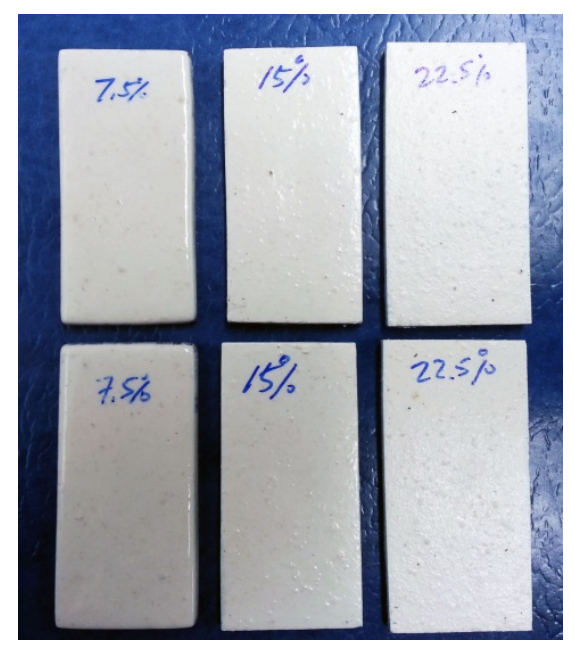

Figure 3.2.1. Fabricated glass plates with varying volume fractions of $\mathrm{ZrO}_{2}$ filler.

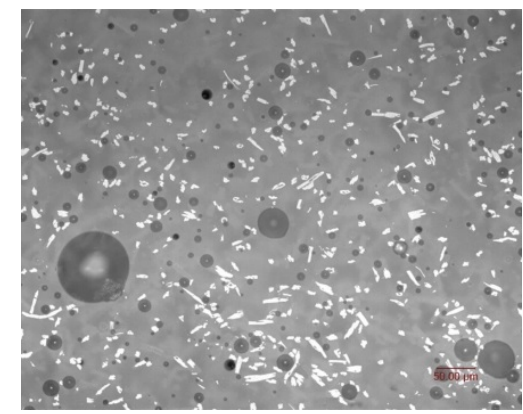

(a)

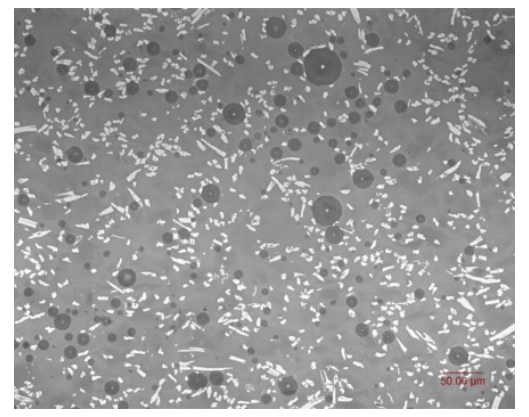

(b)

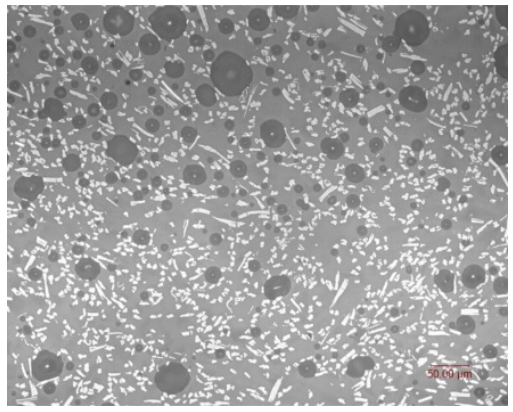

(c)

Figure 3.2.2. Representative microstructural images comparing the volume fraction of the reinforced ceramic filler present among the varying populations, 7.5 (a), 15 (b), and 22.5\% (c). 


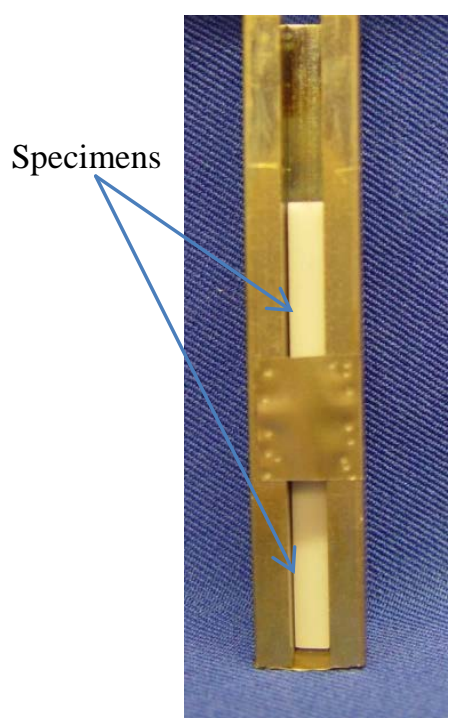

(a)

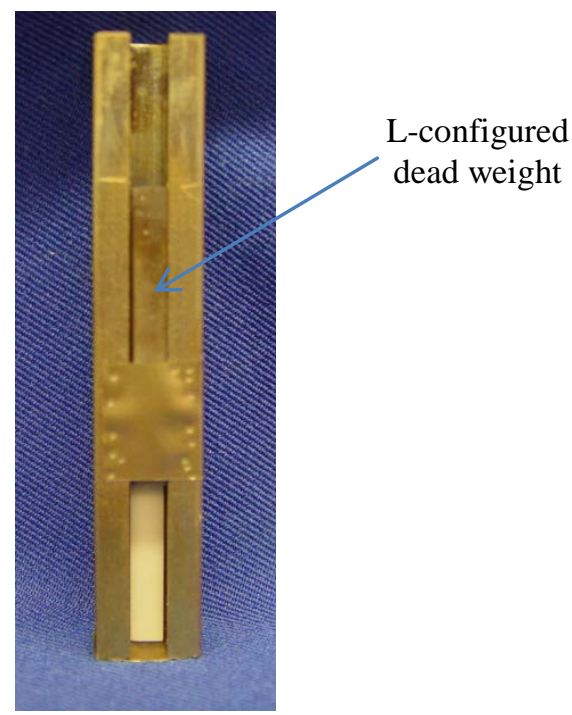

(b)

Figure 3.2.3. Image of two glass bars placed vertically into the channeled, test fixture (a). Image (b) is representative of glass bar specimens exposed to pressure at elevated temperatures.

Subsequent four-point bend tests at room temperature were performed to quantify the mechanical strength of the specimens after exposure and to determine the percentage of healing restored for each sample. The crack healing was measured as the recovered flexural strength. Figure 3.2.4 is representative of a healed specimen where the bars were exposed to $850^{\circ} \mathrm{C}$ for 2 minutes. The two bars healed together and minimal evidence of the original interface is left.

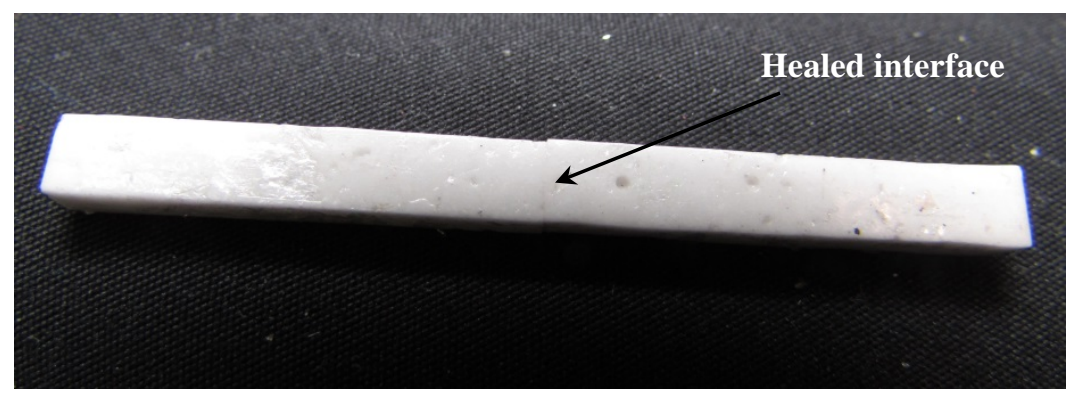

Figure 3.2.4. A $15 \%$ glass specimen exposed to $850^{\circ} \mathrm{C}$ for 2 minutes.

Table 3.2 summarizes the flexural strengths of the specimens that were exposed to elevated temperatures. The four-point bend tests were conducted at room temperature. The flexural strength was determined as:

$$
\frac{3 P L}{2 b d^{2}}
$$


where $P=$ break force, $L=$ outer span, $b=$ specimen width, and $d=$ specimen thickness. The outer span of the test fixture was $40 \mathrm{~mm}$. As the dwell time increases at each test temperature, the flexural strength increases, hence indicating the specimens are reaching healing saturation. When comparing the effect of reinforced filler present, more healing time was required for the 15 and $22.5 \%$ specimens at the $10 \mathrm{w}, 700^{\circ} \mathrm{C}$ test temperature.

Table 3.2. Flexural tests results summary.

\begin{tabular}{|c|c|c|c|c|c|c|}
\hline Specimen & $\begin{array}{c}\text { Temperature } \\
\left({ }^{\circ} \mathrm{C}\right)\end{array}$ & $\begin{array}{c}\text { Time } \\
@ \text { Temp } \\
\text { (min) }\end{array}$ & $\begin{array}{c}\% \\
\text { Filler }\end{array}$ & $\begin{array}{l}\text { Max Load } \\
\text { (N) }\end{array}$ & $\begin{array}{l}\text { Flexural Strength } \\
\qquad(\mathrm{MPa})\end{array}$ & $\begin{array}{l}\text { Failure } \\
\text { Location }\end{array}$ \\
\hline 7.5_700_80 & 700 & 80 & 7.5 & 34.7 & 28.9 & $\begin{array}{l}\text { Healed faying } \\
\text { surface }\end{array}$ \\
\hline 7.5_700_180 & 700 & 180 & 7.5 & 41.8 & 34.8 & $\begin{array}{l}\text { Healed faying } \\
\text { surface }\end{array}$ \\
\hline 7.5_800_5 & 800 & 5 & 7.5 & 45.3 & 37.8 & $\begin{array}{l}\text { Healed faying } \\
\text { surface }\end{array}$ \\
\hline 7.5_800_10 & 800 & 10 & 7.5 & 60.0 & 50.0 & \\
\hline 7.5_800_20 & 800 & 20 & 7.5 & 59.6 & 49.6 & \\
\hline 7.5_850_1 & 850 & 1 & 7.5 & 31.1 & 25.9 & $\begin{array}{l}\text { Healed faying } \\
\text { surface }\end{array}$ \\
\hline $7.5 \_850 \_3$ & 850 & 3 & 7.5 & 75.6 & 63.0 & \\
\hline 15_700_180 & 700 & 180 & 15 & 64.9 & 54.1 & \\
\hline 15_700_300 & 700 & 300 & 15 & 55.1 & 45.9 & $\begin{array}{l}\text { Healed faying } \\
\text { surface }\end{array}$ \\
\hline $15 \_800 \_5$ & 800 & 5 & 15 & 62.2 & 51.9 & $\begin{array}{l}\text { Healed faying } \\
\text { surface }\end{array}$ \\
\hline 15_800_10 & 800 & 10 & 15 & 64.4 & 53.7 & \\
\hline 15_800_20 & 800 & 20 & 15 & 66.7 & 55.6 & \\
\hline 15_850_2 & 850 & 2 & 15 & 40.9 & 34.1 & $\begin{array}{l}\text { Healed faying } \\
\text { surface }\end{array}$ \\
\hline $15 \_850 \_3$ & 850 & 3 & 15 & 68.0 & 56.7 & \\
\hline 22.5_700_4080 & 700 & 4080 & 22.5 & 35.1 & 29.3 & $\begin{array}{l}\text { Healed faying } \\
\text { surface }\end{array}$ \\
\hline 22.5_700_6480 & 700 & 6480 & 22.5 & 53.8 & 44.8 & $\begin{array}{l}\text { Healed faying } \\
\text { surface }\end{array}$ \\
\hline $22.5 \_800 \_5$ & 800 & 5 & 22.5 & 6.2 & 5.2 & $\begin{array}{l}\text { Healed faying } \\
\text { surface }\end{array}$ \\
\hline 22.5_800_10 & 800 & 10 & 22.5 & 68.4 & 57.0 & $\begin{array}{l}\text { Healed faying } \\
\text { surface }\end{array}$ \\
\hline 22.5_800_20 & 800 & 20 & 22.5 & 72.9 & 60.7 & \\
\hline $22.5 \_850 \_2$ & 850 & 2 & 22.5 & 47.1 & 39.3 & $\begin{array}{l}\text { Healed faying } \\
\text { surface }\end{array}$ \\
\hline $22.5 \_850 \_3$ & 850 & 3 & 22.5 & 77.8 & 64.8 & $\begin{array}{l}\text { Healed faying } \\
\text { surface }\end{array}$ \\
\hline
\end{tabular}


Several more tests will continue in early Q2 where completion of the baseline strengths will be performed on specimens for each varying filler volume fraction. The flexural strength of the virgin material is expected to change with the amount of reinforcement, but there was not enough glass material available to perform these tests. 